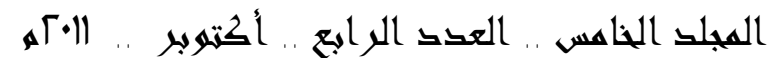

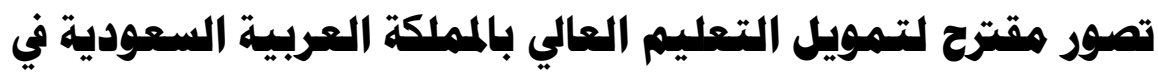

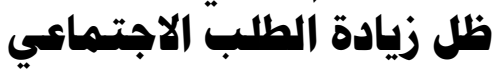

منال حسين حسن الحميلي

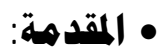

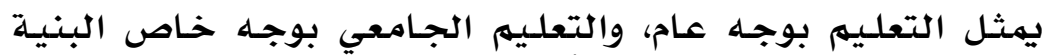

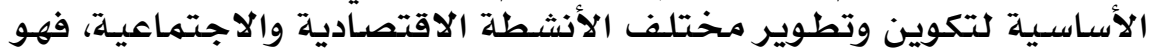

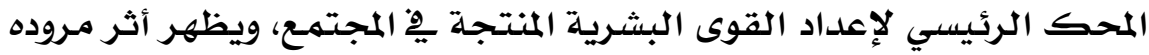

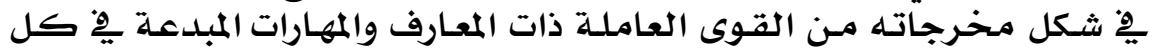

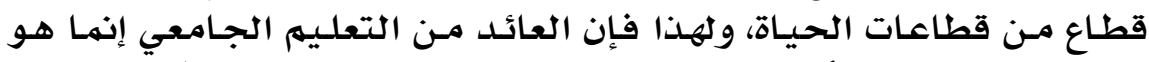

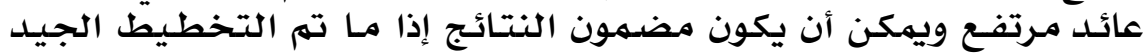

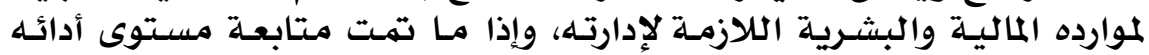

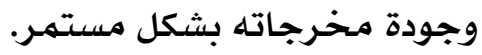

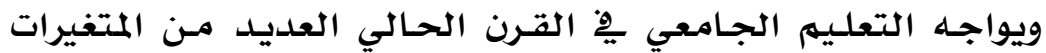

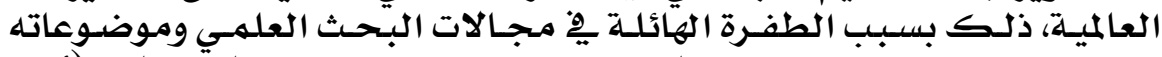

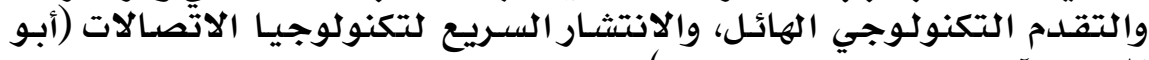

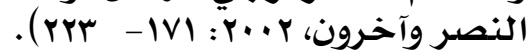

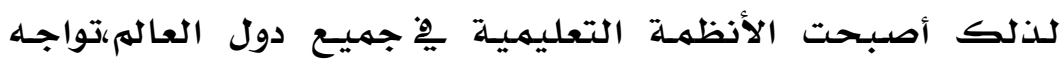

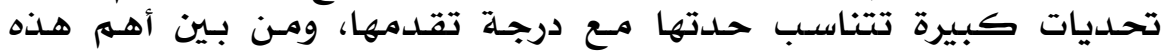

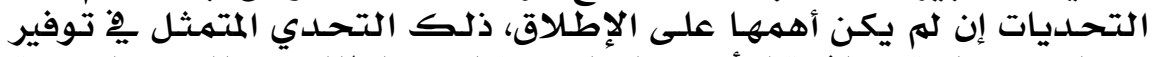

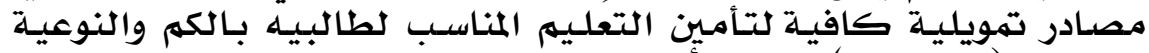

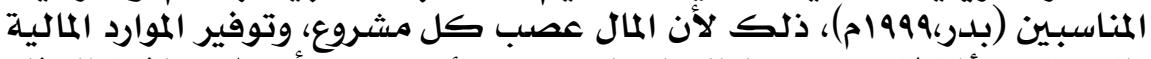

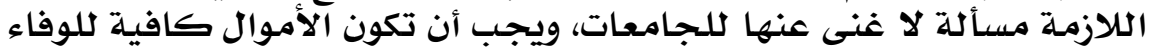

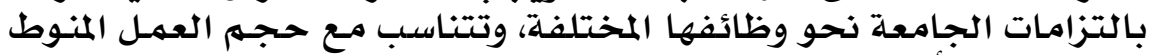

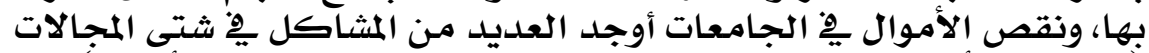

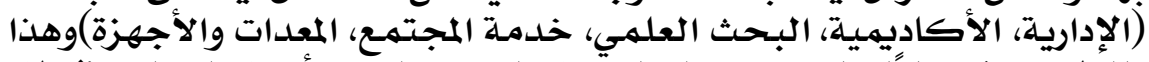

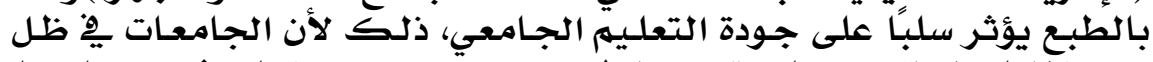

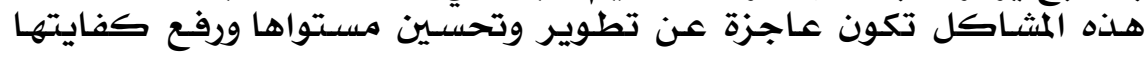

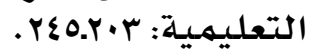

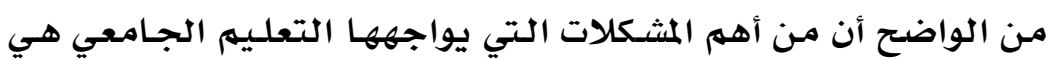

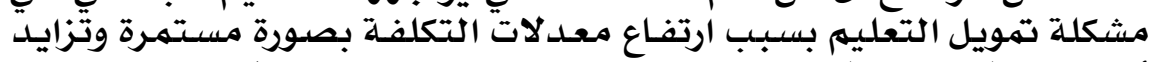

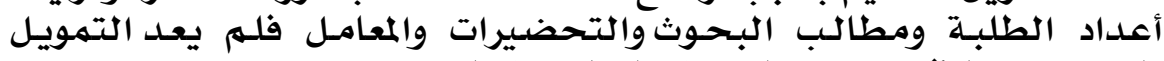

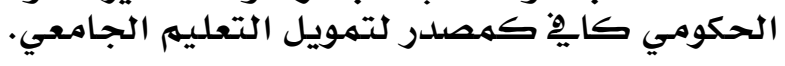

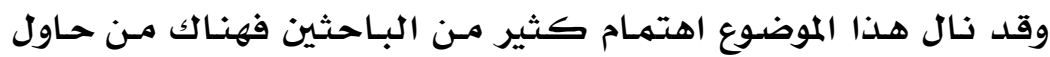

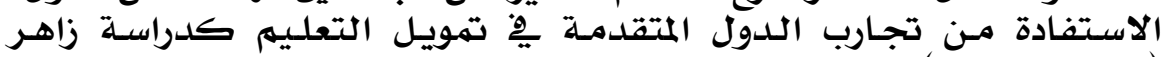

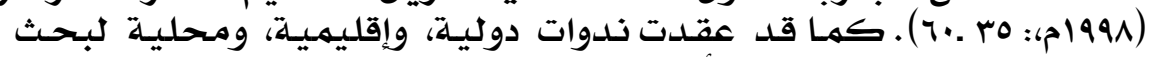

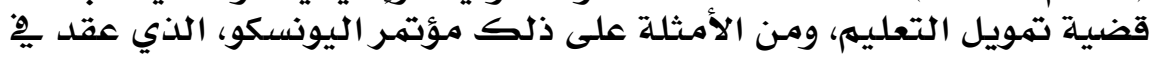

\section{$q \cdot r$}




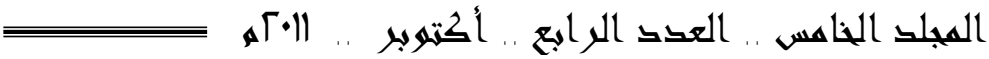

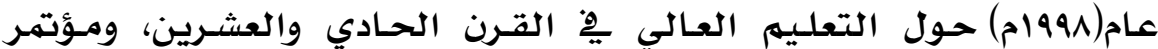

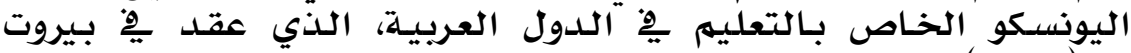

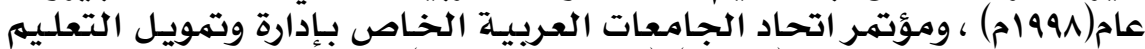

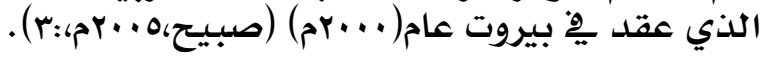

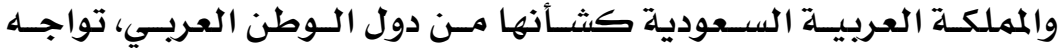

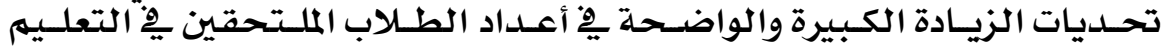

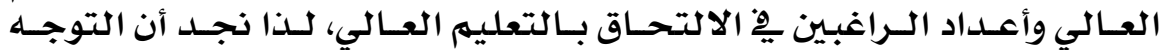

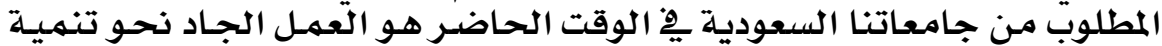

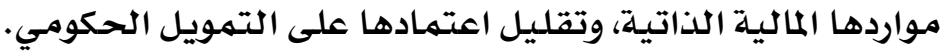

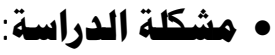

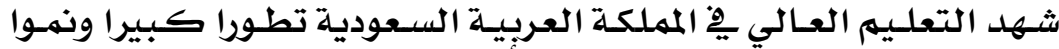

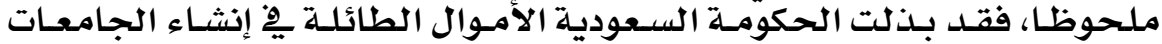

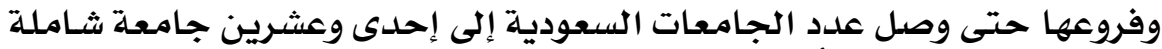

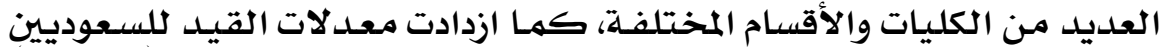

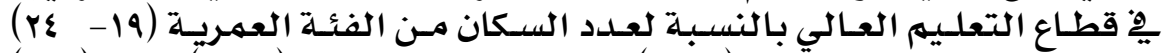

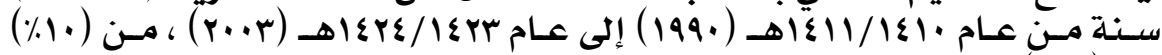

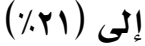

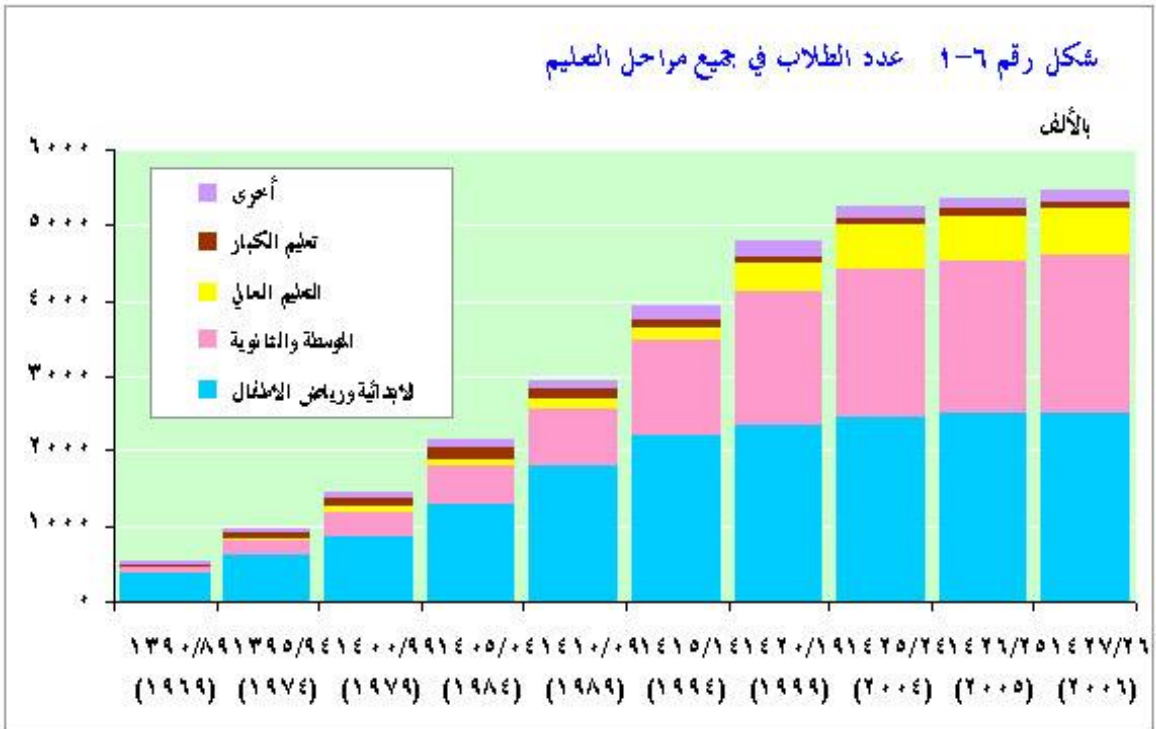

/http://www.planning.gov.sa

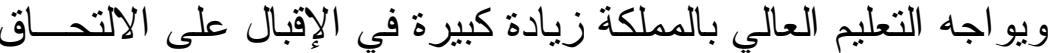

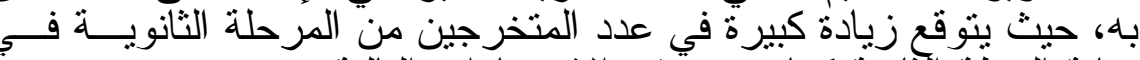

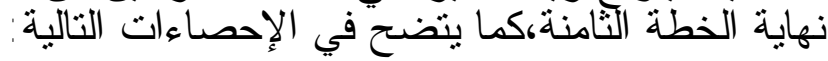

\section{$9 \cdot \varepsilon$}

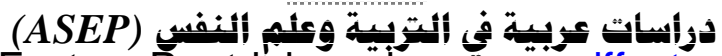




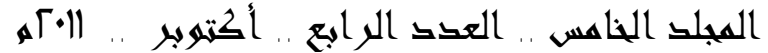

العدد المتوقع للطلبة المتخرجين من المرحلة الثانويةحسب المناطق الإدارية والتخصص (خطة التنمية الثامنة)

\begin{tabular}{|c|c|c|c|c|c|c|}
\hline \multicolumn{2}{|c|}{ 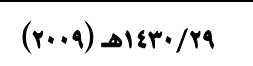 } & \multicolumn{2}{|c|}{ 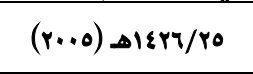 } & \multicolumn{2}{|c|}{ 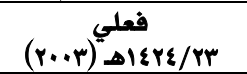 } & \multirow[t]{2}{*}{ المناطق } \\
\hline أدبى & علمى & أدبى & ملمى & أدبى & علمى & \\
\hline YYETV & ro.mr & roqur & rVo40 & $Y \varepsilon \cdot 10$ & 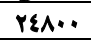 & الرياض \\
\hline YY\&।9 & $\varepsilon Y \Lambda \cdot V$ & Y9.01 & rootr & rorry & rvior & مكة المكرمة \\
\hline$\varepsilon q \cdot \varepsilon$ & VOAT & o\&V\& & $7 \cdot M$ & $77 \varepsilon 0$ & varo & المدينة المنورة \\
\hline TVor & varo & $V \varepsilon q 4$ & $T \varepsilon \varepsilon 1$ & VITE & 7ry. & القصيم \\
\hline $10\{Y \mid$ & ronro & 17974 & $r \cdot \Lambda T$. & lovir & laArr & الشرقية \\
\hline 1.170 & irvro & 11171 & $1 \cdot \varepsilon Y Y$ & 1. ror & 947 & عسير \\
\hline YAY. & $\varepsilon \| 1 \%$ & $r \cdot q r$ & MIE & raYo & rq94 & تبوك \\
\hline req. & mila & rVir & YTAE & $r \leqslant 01$ & rEY. & حائل \\
\hline $19 . r$ & IVVE & $r \cdot \wedge \varepsilon$ & lEr. & 1917 & IYAY & الحلدودالشمالية \\
\hline$\varepsilon \wedge \varepsilon 1$ & 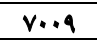 & or\&9 & ovir & ह9Mr & oirt & جازان \\
\hline $1 \leqslant 01$ & rarI & $171 Y$ & rEYI & lov. & YITE & نحران \\
\hline$r \varepsilon \cdot V$ & rAAV & rTON & rior & $r\{00$ & YAEI & الباحة \\
\hline rYAq & Y910 & rolr & rror & YrYI & rirr & الجوف \\
\hline 1.orva & lovara & livior & Irva9o & 1.1111 & II\&^৭Y & الحملة \\
\hline
\end{tabular}

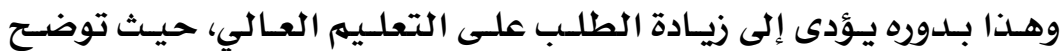

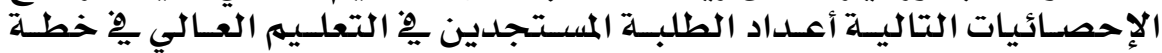

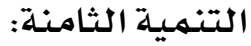

المستجدون ف2 التعليم العالي (خطة التنمية الثامنة)

\begin{tabular}{|c|c|c|c|}
\hline 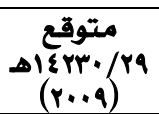 & 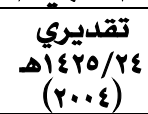 & 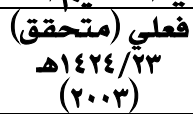 & الجهـة \\
\hline $10 \wedge 997$ & IrI9\&9 & IYTYIE & الحامعات ووكليات البنات \\
\hline $0 . Y_{0}$ & ro.. & ork & الجامعات والكليات الأهلية \\
\hline YY.O & 1900 & $10 \cdot 1$ & الميتعثون إلى الخارج \\
\hline $177 \% Y 7$ & $|r| \varepsilon \cdot \varepsilon$ & IYAYY. & الإجماكي \\
\hline
\end{tabular}

/http://www.planning.gov.sa

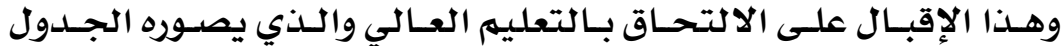

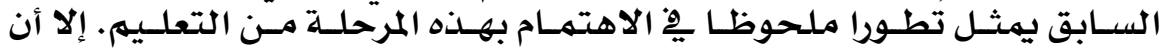

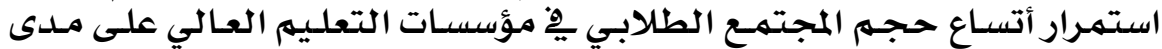

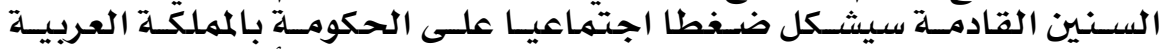

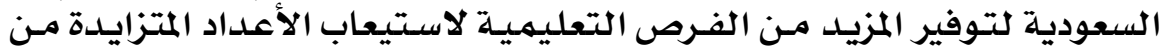

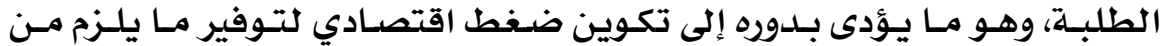

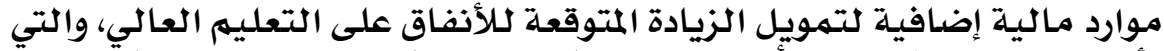

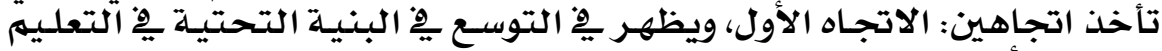

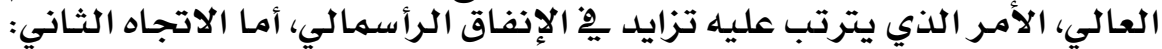

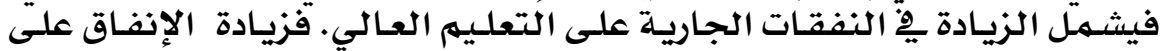

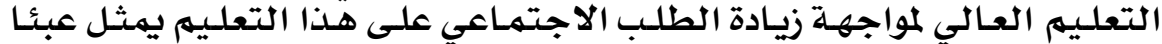

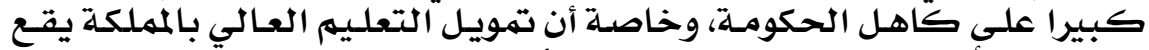

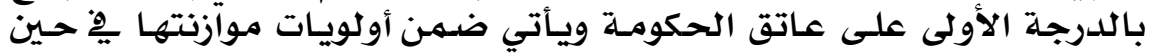

\section{$9 \cdot 0$}




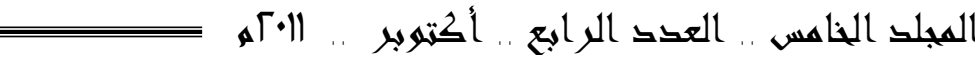

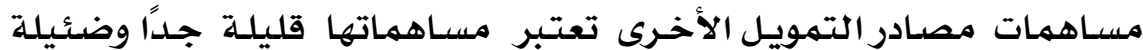

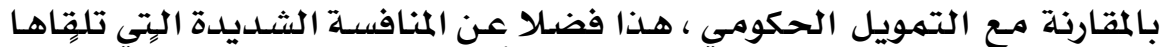

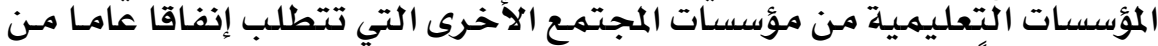

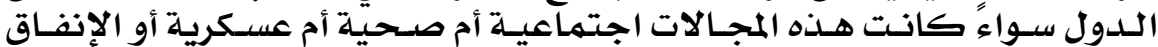

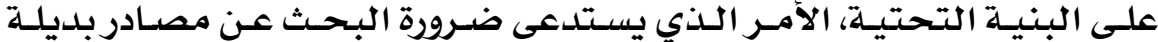

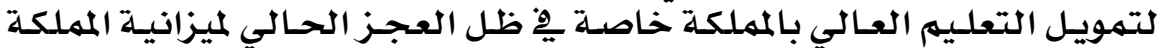

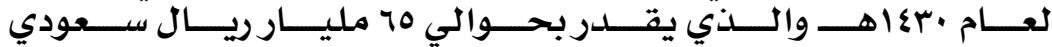
.http://www.ecoworld-mag.com.

\section{• أسئلة الدراسة}

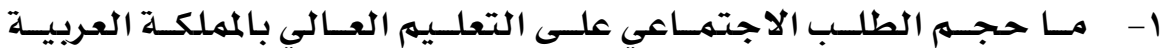

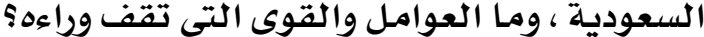

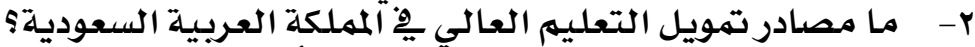

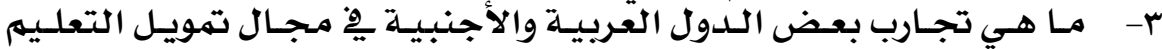

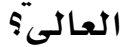

ع- ما التصور المقترح لتمويل التعليه العالي يِّ المملكة العربيـة السعودية يِّ ظل زيادة الطلب الاجتمعاعي؟ التهوئ التعاع

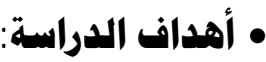

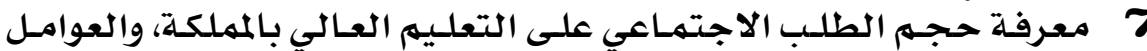

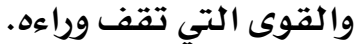
7

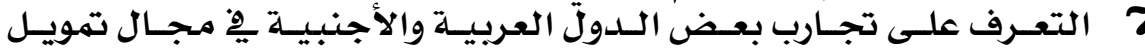

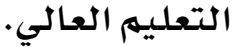

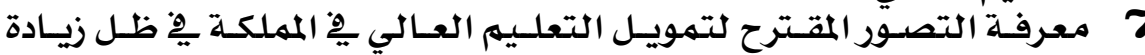

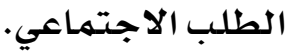

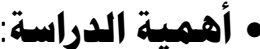

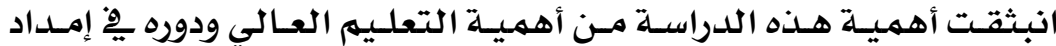

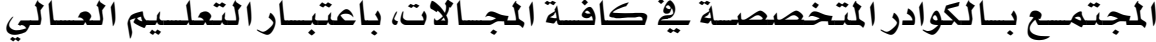

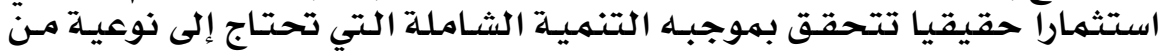

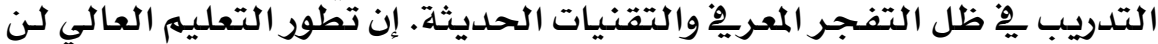

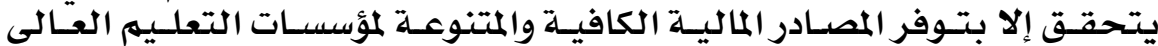

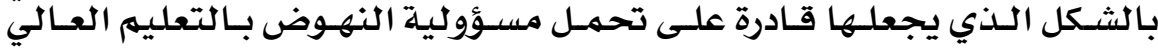

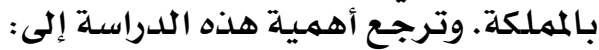

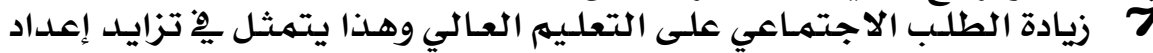

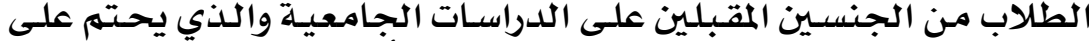

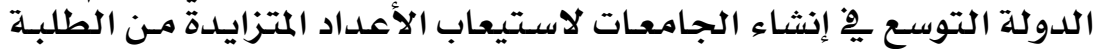

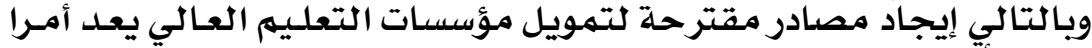

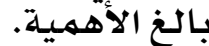
7 التوجهات العالميـة المصدحوبة بـالتطور العلهـي الـتي تسـتدعي بحث بــائل

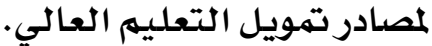

\section{$9 \cdot 7$}




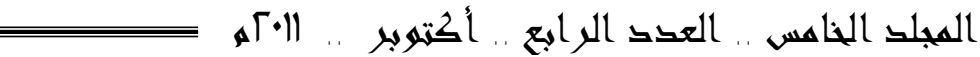

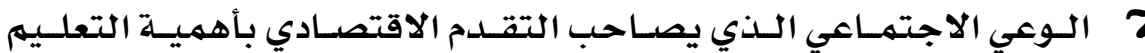

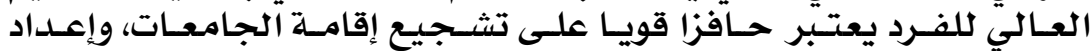

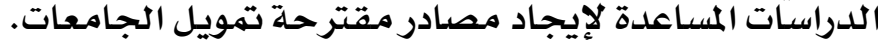

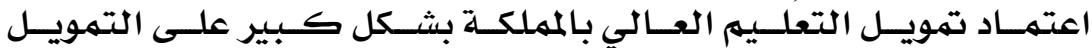

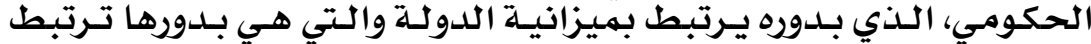

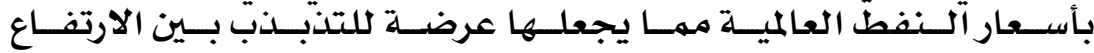

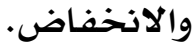

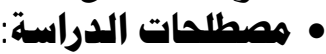

التمويل : التوحماء

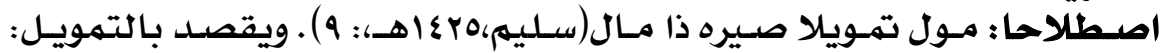

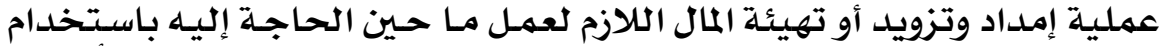

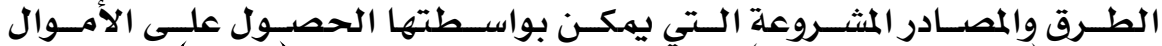

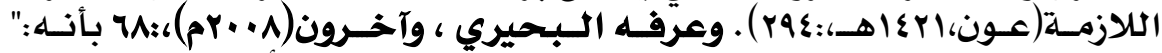

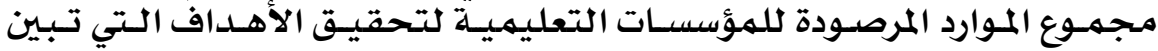

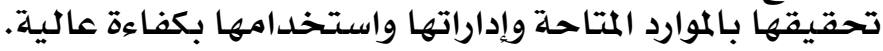

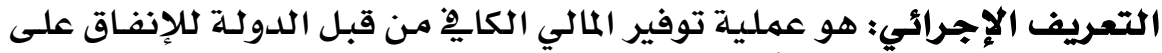

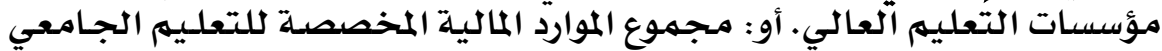
من الموازنة العامـة للدولثة.

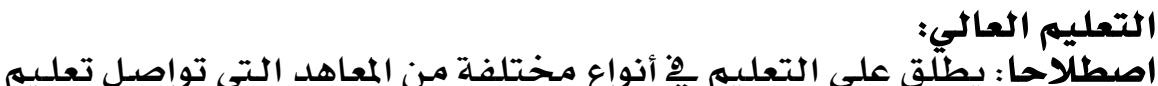

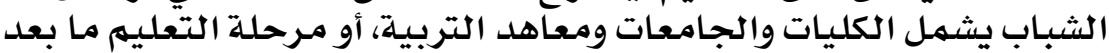

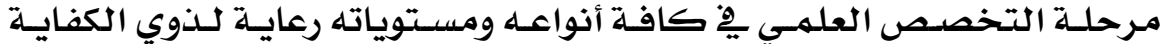

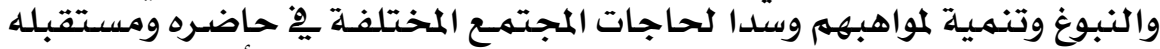

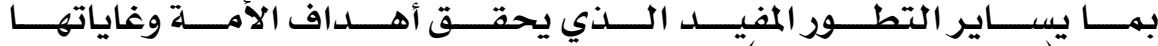

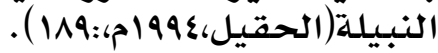

التعريف الإجرائي: يقصلد به كل مؤسسات التعليم التي تلي المرحلة الثانوية. الطلب الاجتماعي على التعليم العالي: الإجمري:

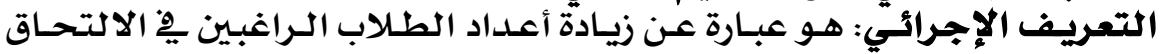

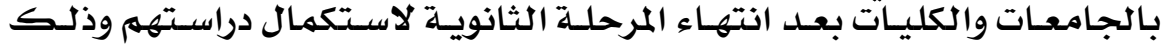

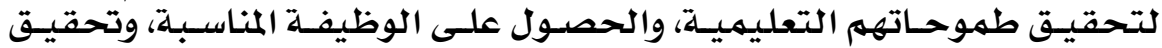

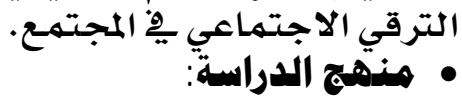

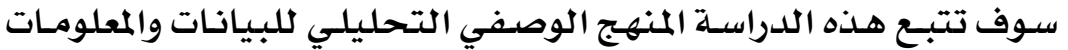

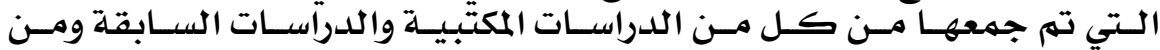

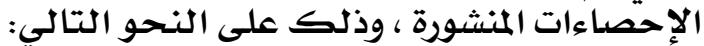

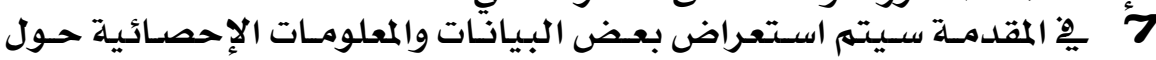

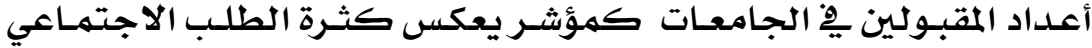

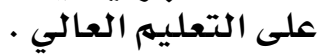

\section{V}


7

7

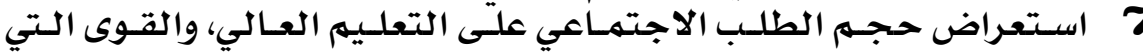

تقف وراءه.

7

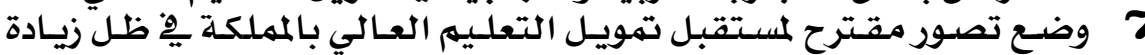

الطلب الاجتماعي.

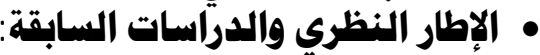

أولا : الإطار النظري : الإطار النظري

التعليه العالي ف2 المملكة العريية السعودية:

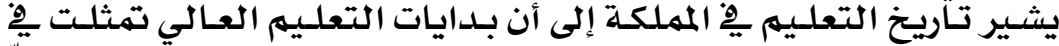

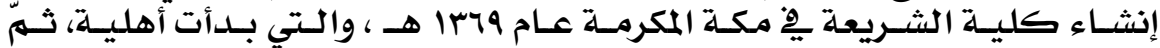

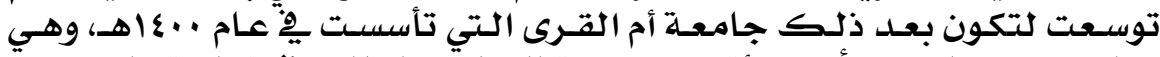

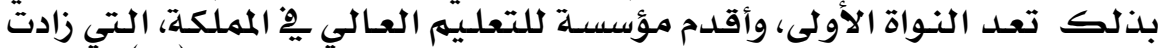

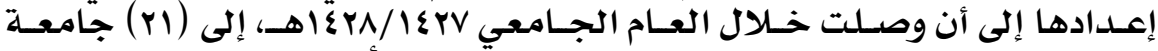

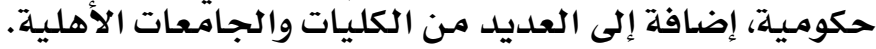

أ- نظام التعليم العادي بالمملكة العرية الميلية السعودية:

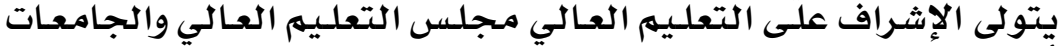

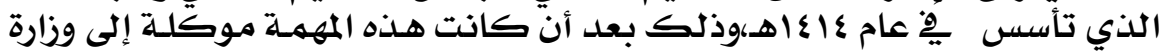

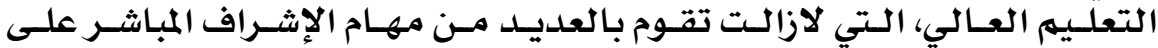

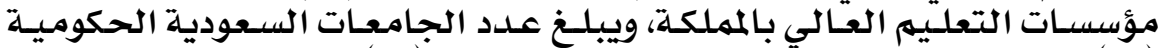

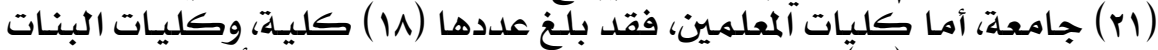

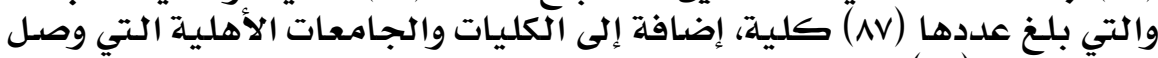

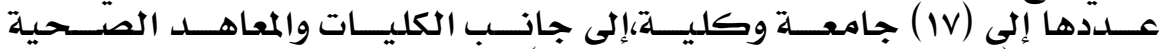

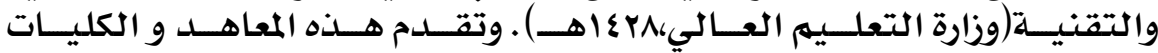

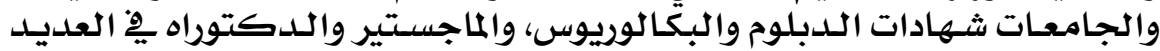

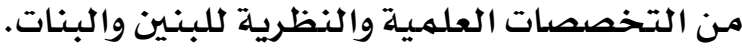

ب- هيعات ومؤسسات وبرامج التعليم العالي بالمملكة العربية السعودية:

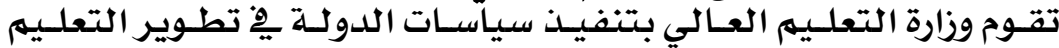

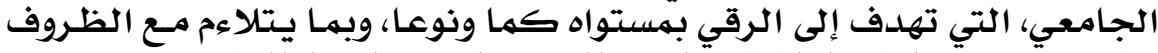

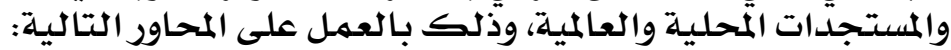

$$
7
$$

7

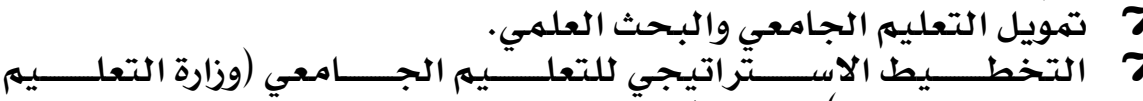

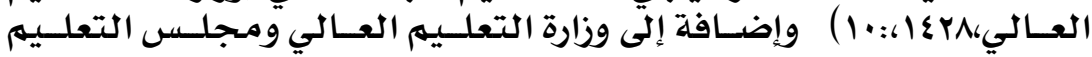

\section{1}




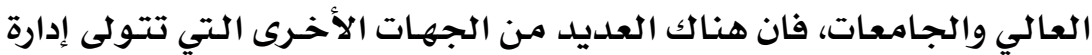

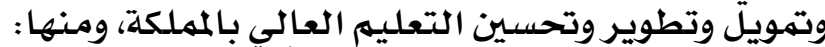

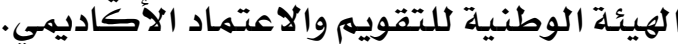

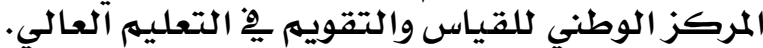

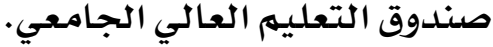
مركز إحصاءات التعليه العاليه الجاليعي.

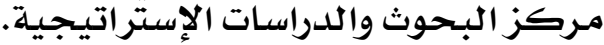

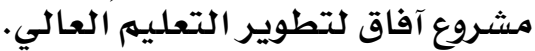

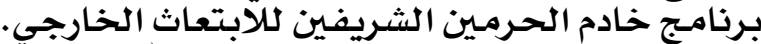

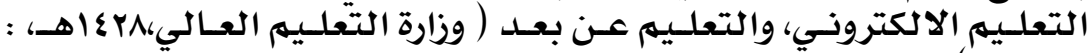
. أهداف التعليم العالي كما حلددتها السياسياسية التعليمية بالمملكة:

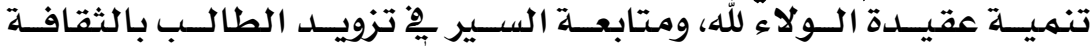

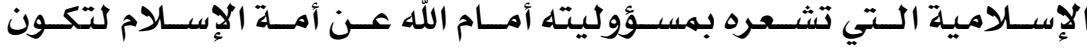

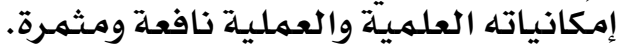

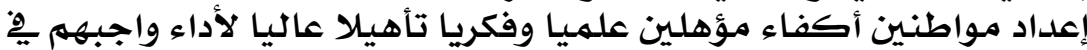

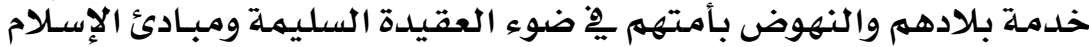

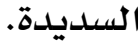
إتاحسة الفرصسة أمـام النـابغين لمواصـلة دراسـاتهم العليـا يِّ التخصصـات

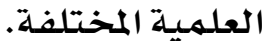

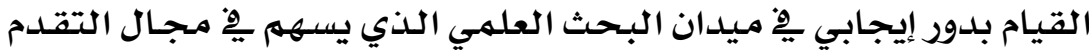

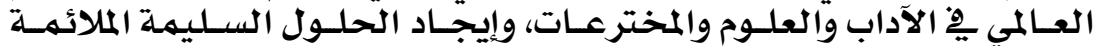

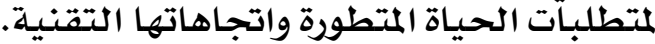

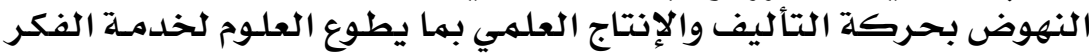

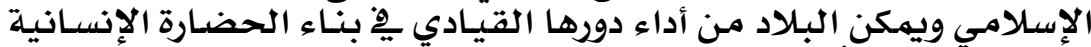

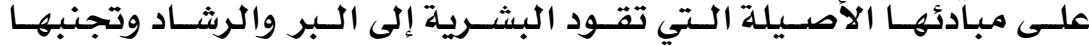
الانحرافات المادية والإلحادية الإدية.

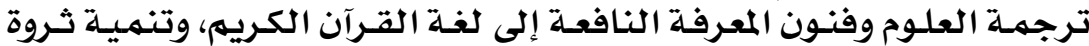

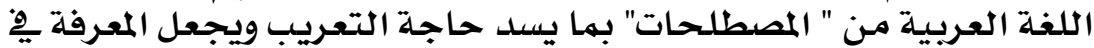

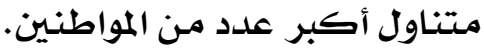

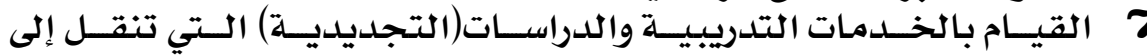

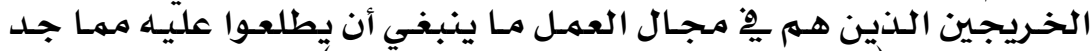

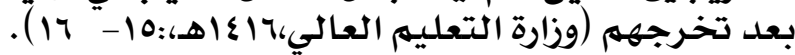

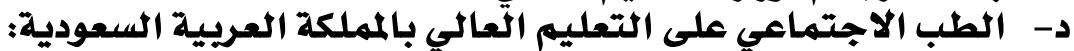

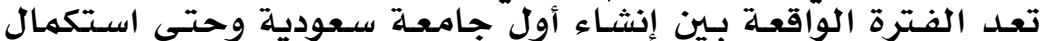

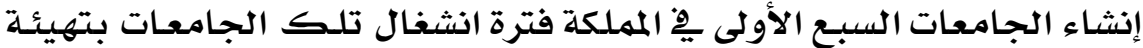

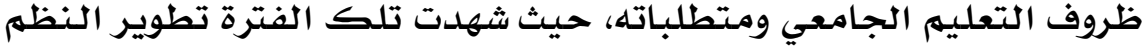

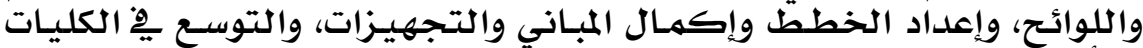

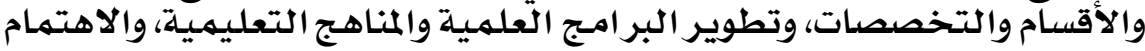

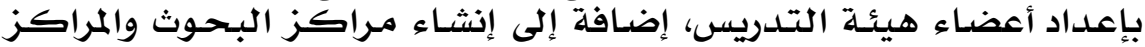

\section{$9 \cdot 9$}




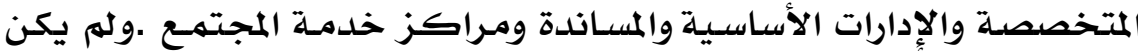

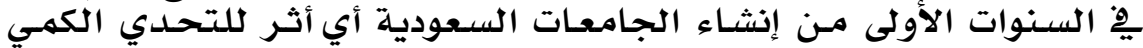

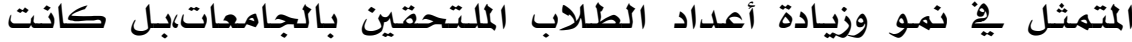

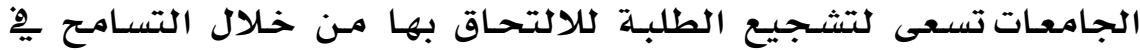

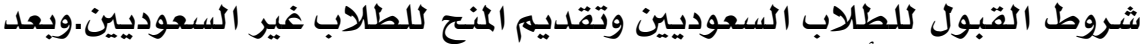

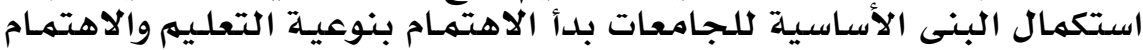

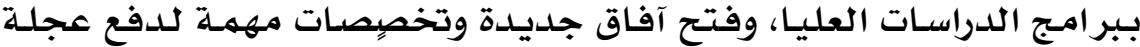

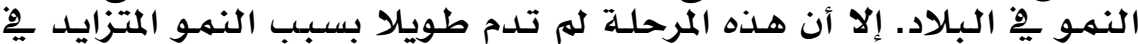

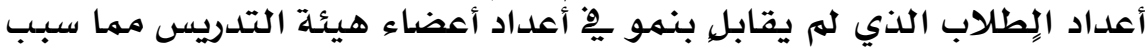

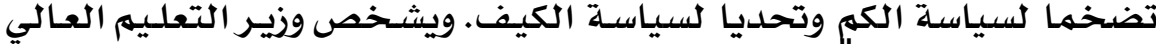

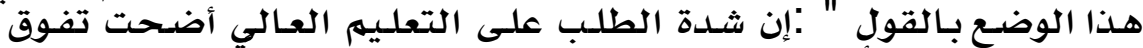

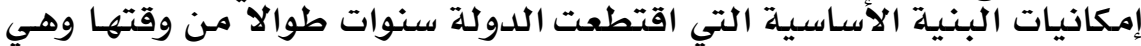

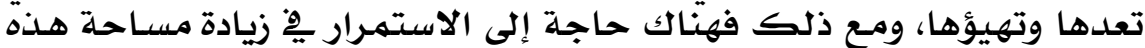

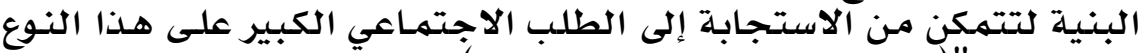

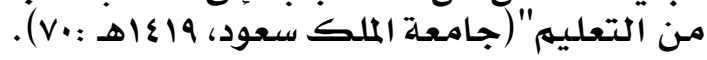

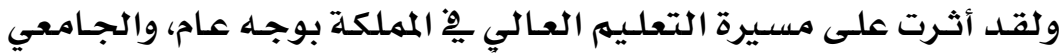

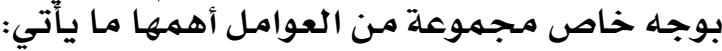

7

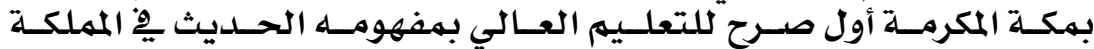

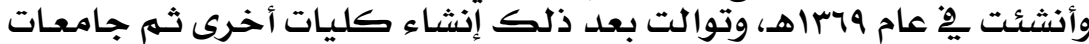

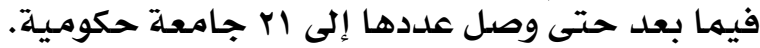

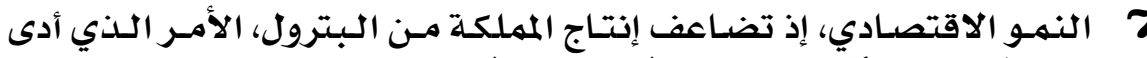

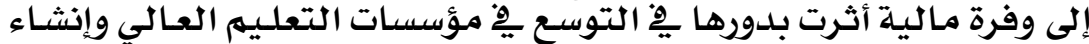
جامعات جديدة.

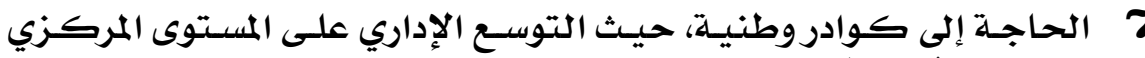

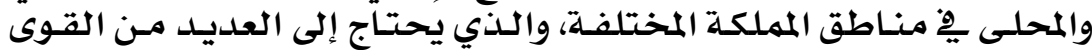

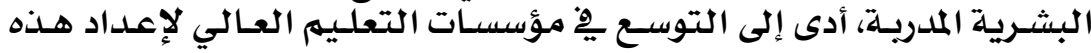

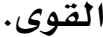

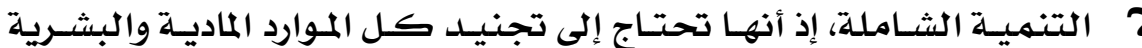

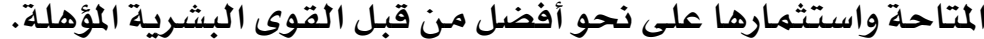

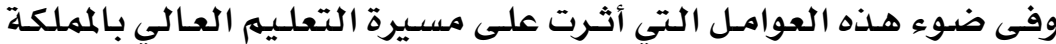

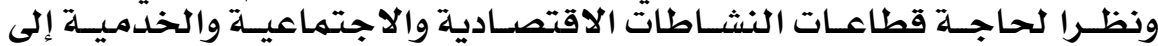

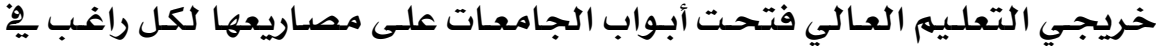

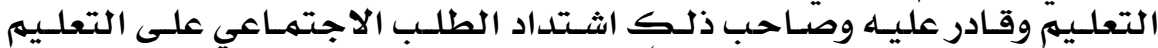

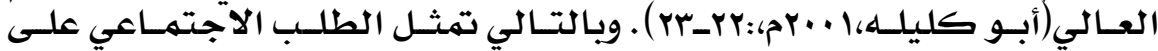

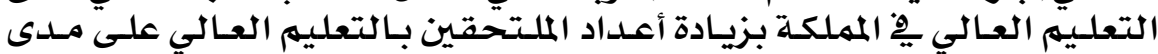

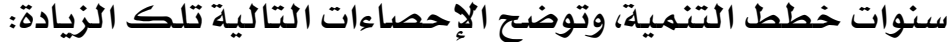

\section{1.}

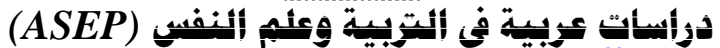




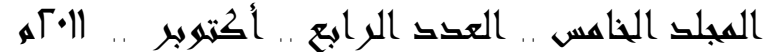
المستجدون (ذكوروإناث) مِ التعليم العالي

\begin{tabular}{|c|c|}
\hline عدد المستجدين ـِ الجامعات والكليات & العام \\
\hline 10N74 & $|\varepsilon \cdot Y /| \varepsilon \cdot 1$ \\
\hline YAYAT & $1 \varepsilon \cdot 7 / 1 \varepsilon \cdot 0$ \\
\hline rq00. & $|\varepsilon| 1 /|\varepsilon|^{2}$ \\
\hline $7 r \cdot \varepsilon 1$ & $1817 / 1810$ \\
\hline VA... & $1 \varepsilon r \cdot /|\varepsilon| q$ \\
\hline
\end{tabular}

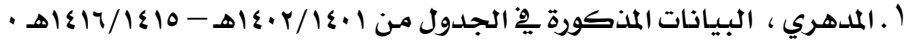

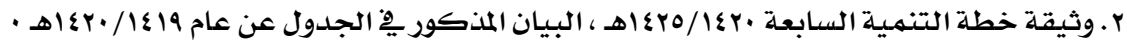
المستحدون (ذكوروإناث) فو التعليم العالي

\begin{tabular}{|c|c|}
\hline عدد المستجدين 2ِ الجامعاتة والكليات & 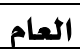 \\
\hline 179, r77 & $1 \& r \mu$ \\
\hline IAV,YAq & $1 \varepsilon r \varepsilon$ \\
\hline$|\varepsilon|, M V \mid$ & 1\&Yo \\
\hline $10 \varepsilon, 1 \varepsilon \wedge$ & $1 \& Y 7$ \\
\hline $171, \cdot v 9$ & $1 \& \gamma V$ \\
\hline IAY,YYQ & $1 \varepsilon r \wedge$ \\
\hline 199,Amr & 1\&Yq \\
\hline
\end{tabular}

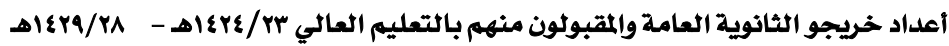

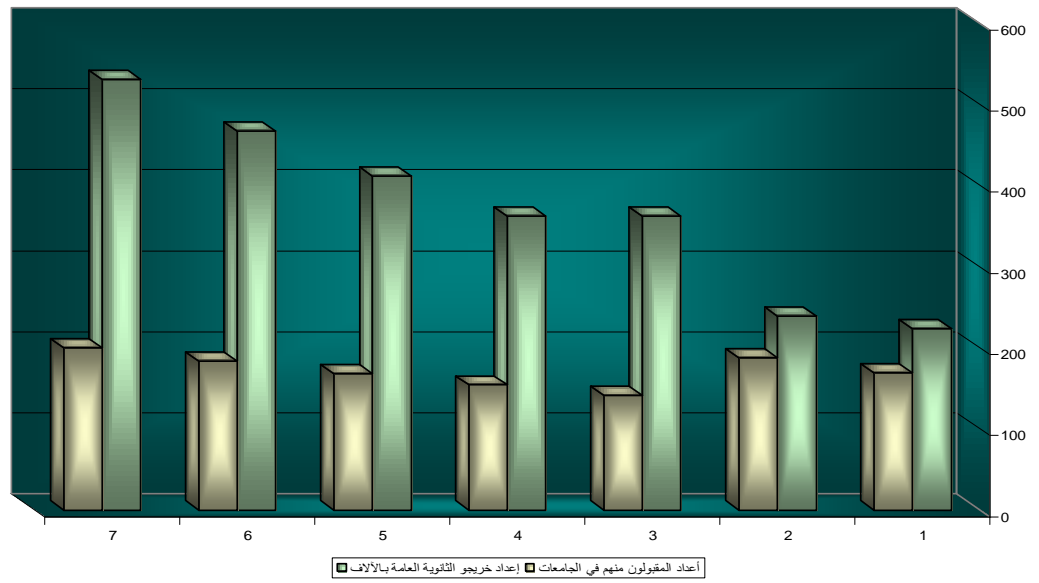

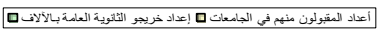

المصلدر:

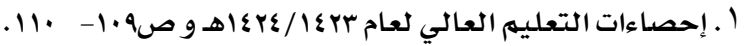

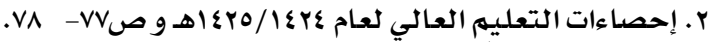

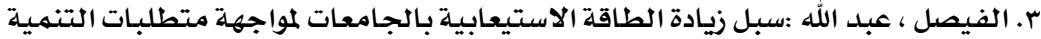
المستقبلية.الفيدل،

\section{1}

\section{دوالسات عربية في ألتبية وعأم ألفنسي (ASEP)}




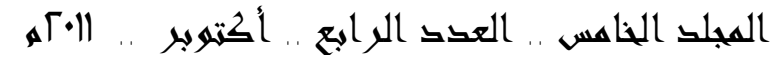

$$
\text { ويتضح لنا من العرض السابق أمـران: }
$$

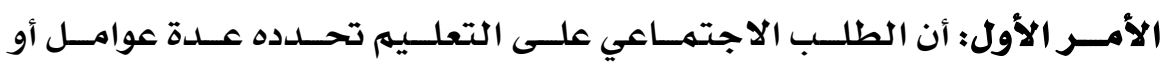

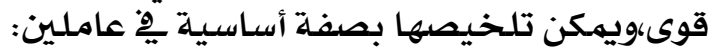

7

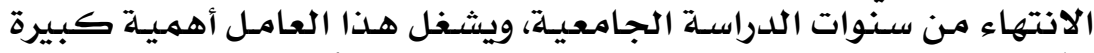

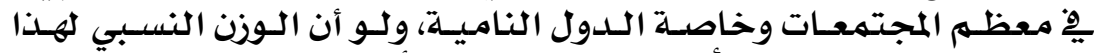

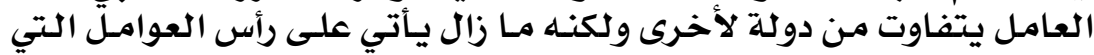

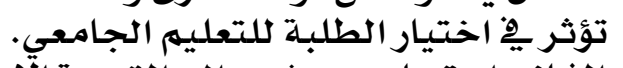

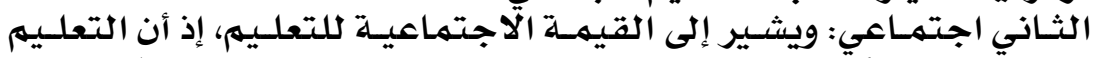

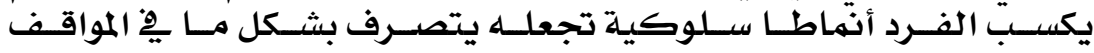

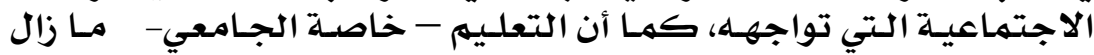

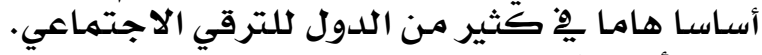

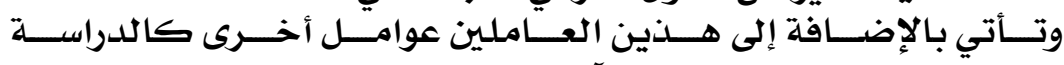

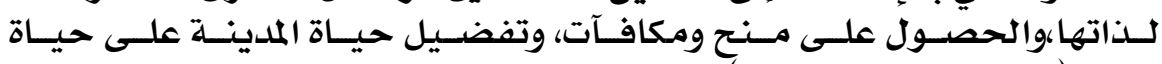

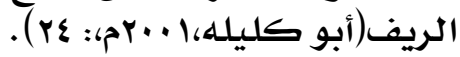
ويـرى كـوميز(بـدون) أن هنـاك عـدة قـوى وراء الطلب الاجتهـاعي على التعليهم هي: ويـري:

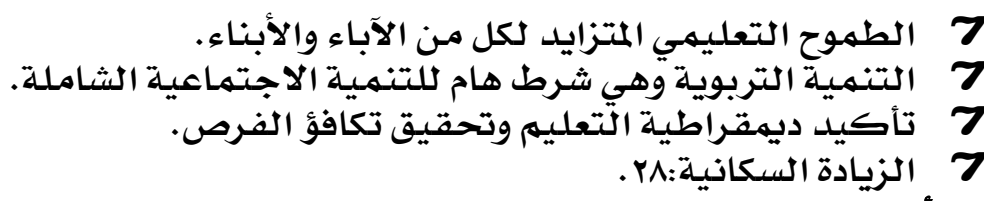

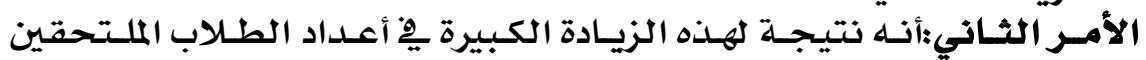

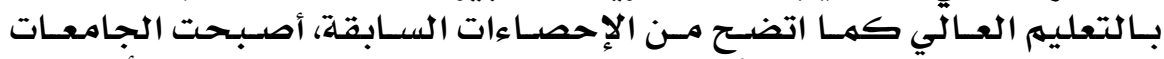

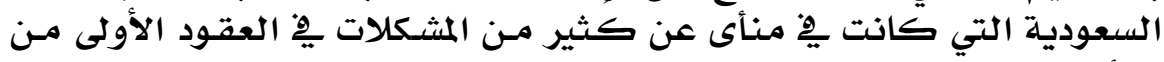

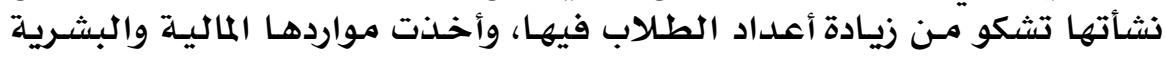

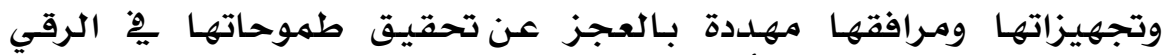

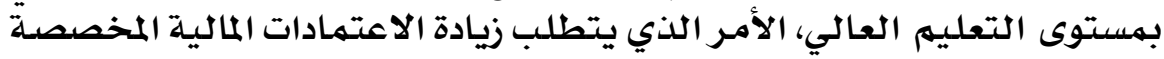

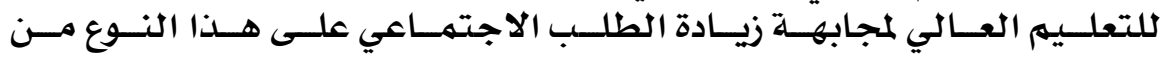

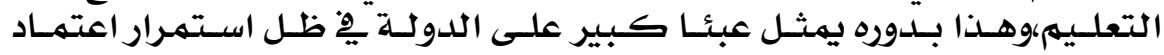

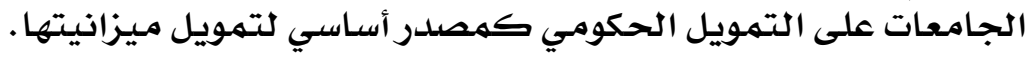

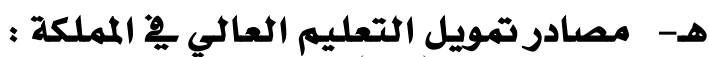

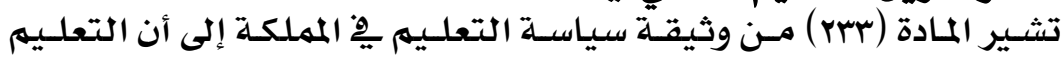

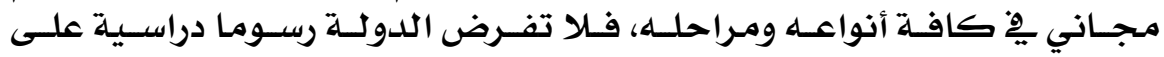

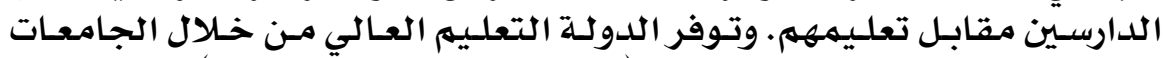

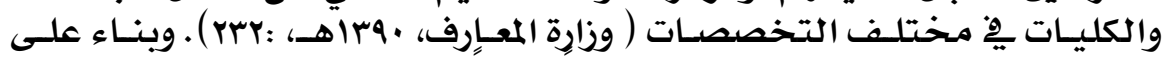

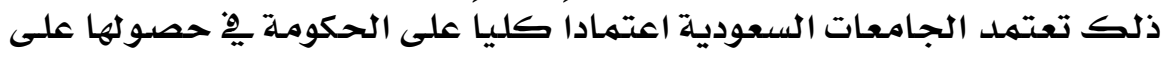

\section{$91 Y$}




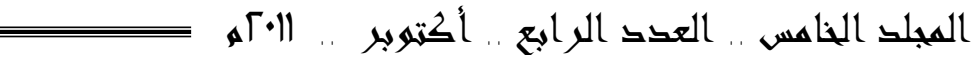

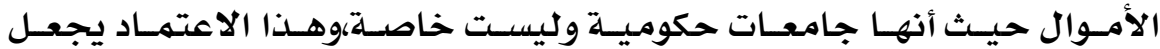

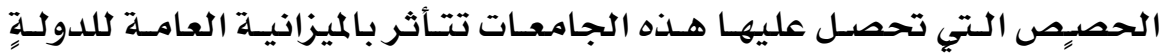

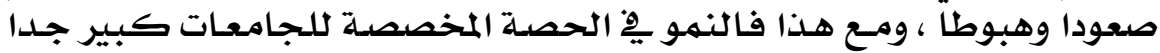

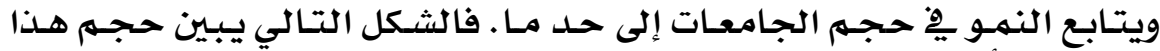

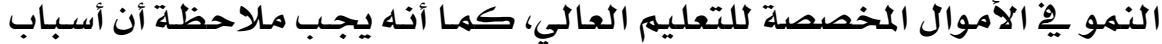

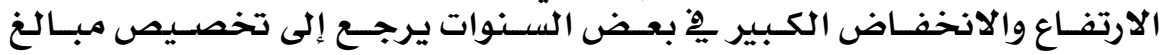
لإنشاء المثاريع أو الانتهاء الإنفاء من بناء بعض بعض المثاريع.

شكل (†) تطور ميزانية التعليم العالي في السعودية

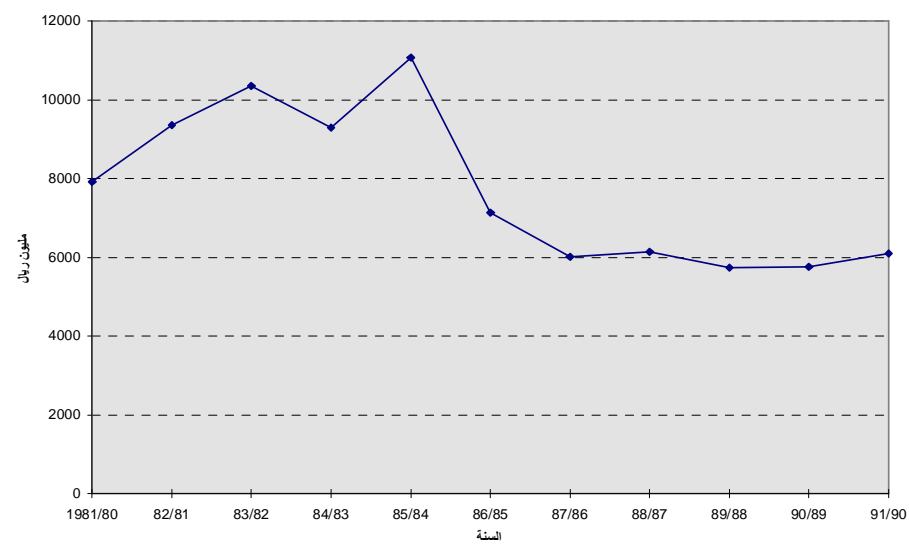

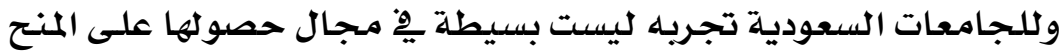

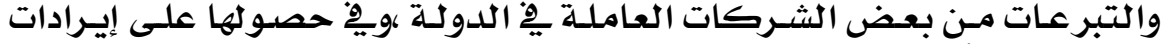

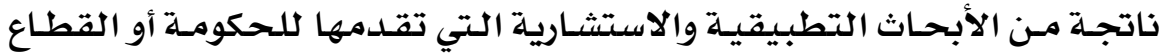

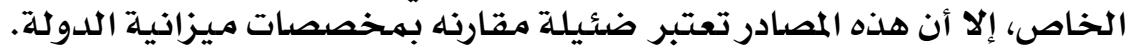

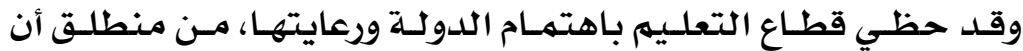

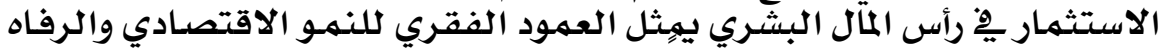

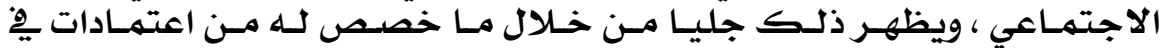

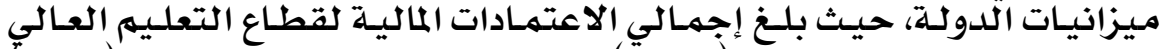

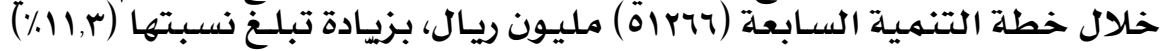

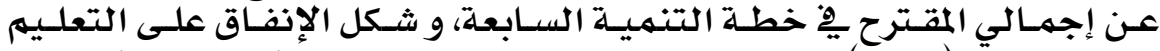

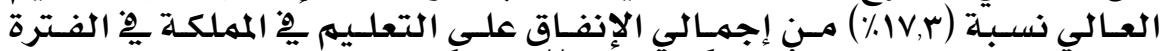

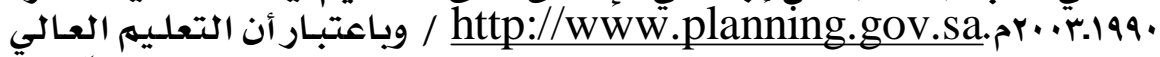

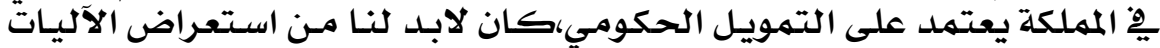

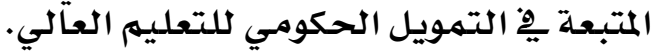

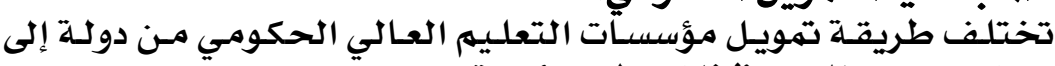

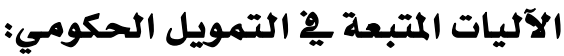
أخرى، ويمكن حصر ذلك بِّن ثلاث طرق رئيسة هي:

\section{$91 \%$}




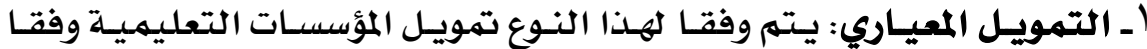

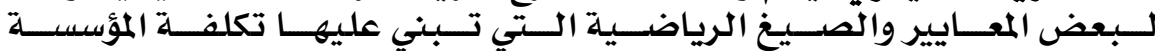
التعليمية،ويتهم حساب التمويل المعياري بعدة صيخ المين منها :

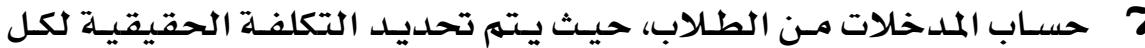

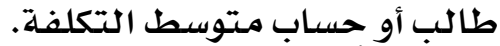

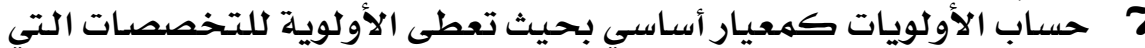

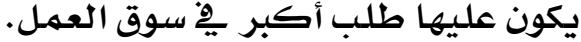

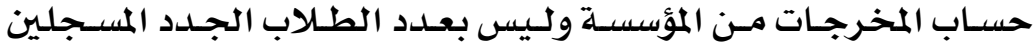

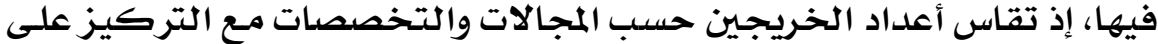

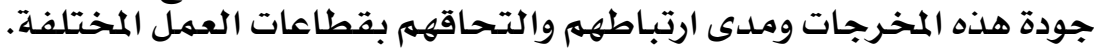

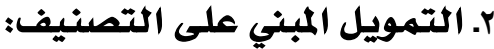

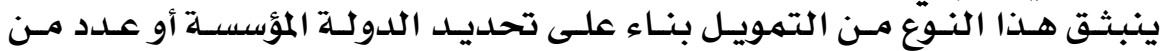

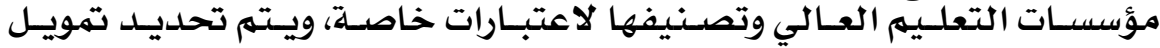
خاص بها ودعمها.

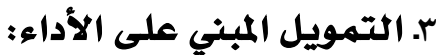

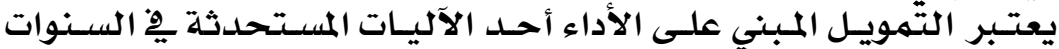

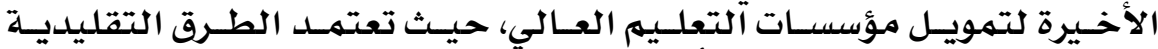

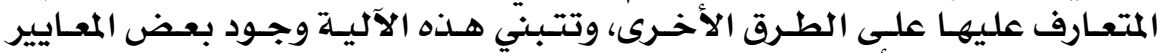

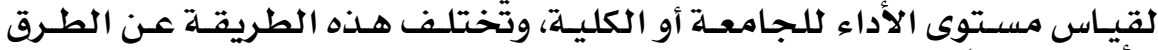

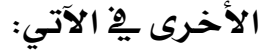

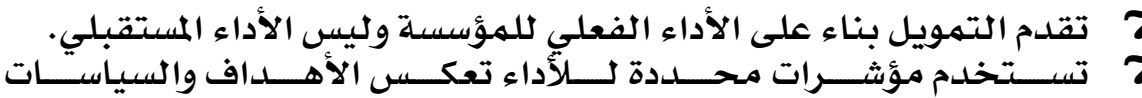

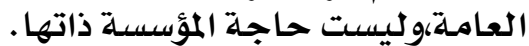

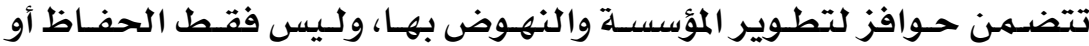
البقاء على مكانتها ومستواهـا.

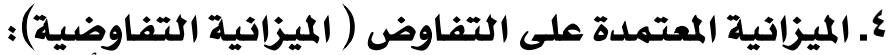

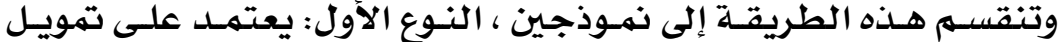

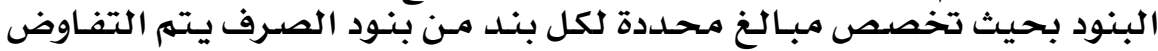

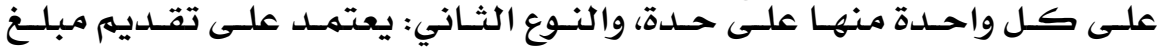

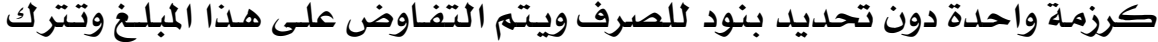

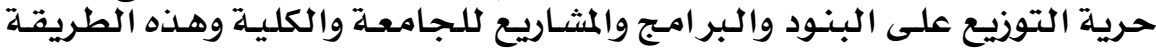

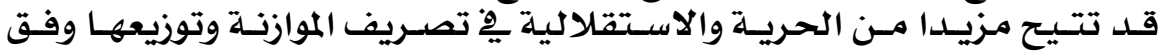

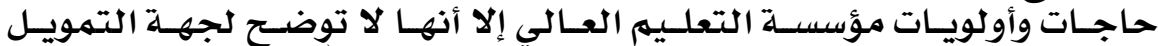

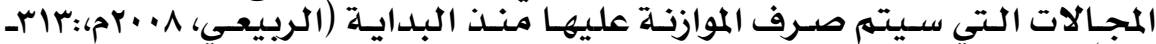

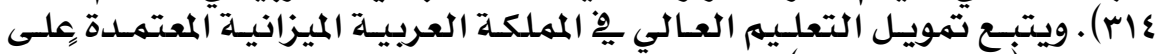

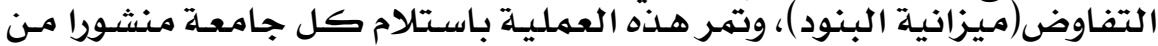

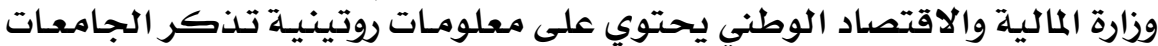

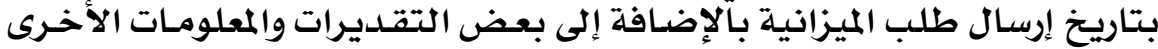

\section{$9) \varepsilon$}




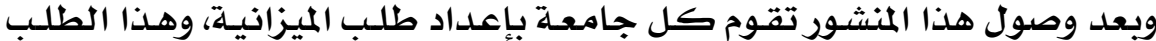

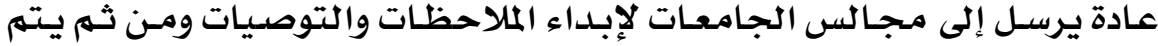

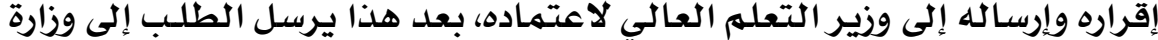

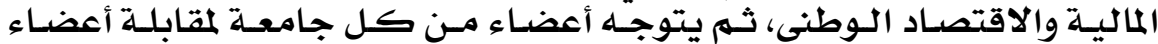

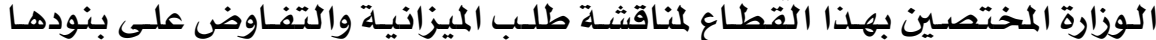

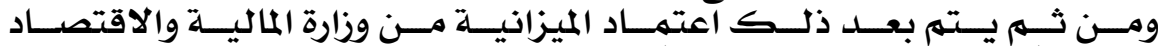

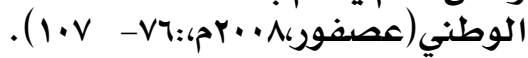

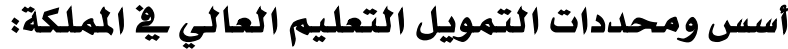

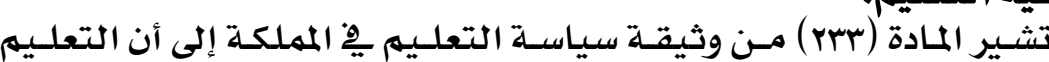
اـ مجاثية التمليبه:

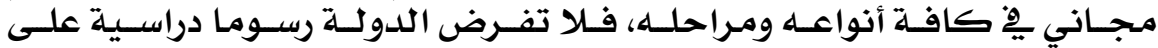

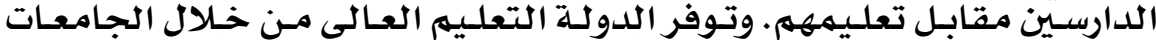

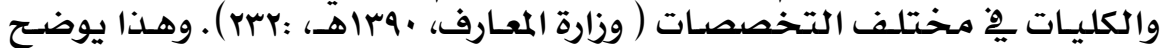

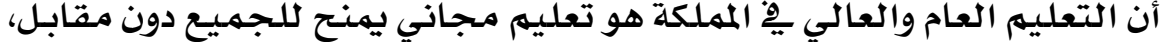

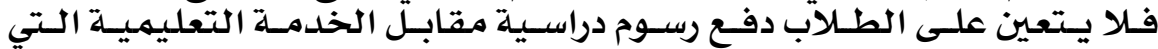

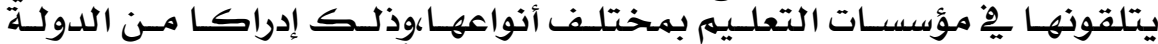

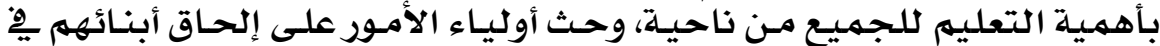

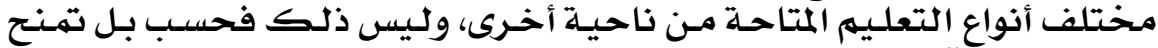

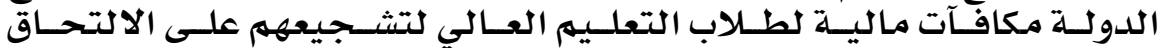

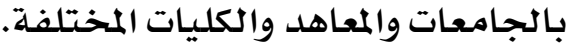

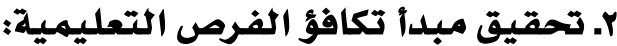

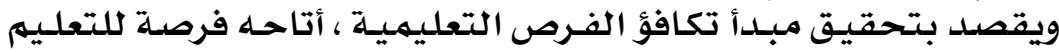

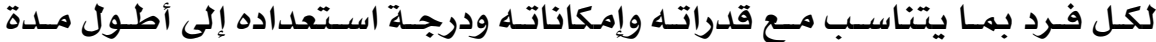

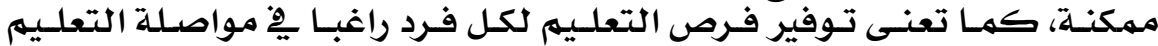

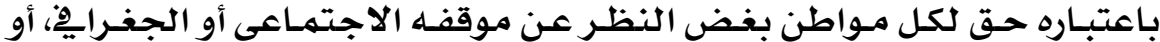

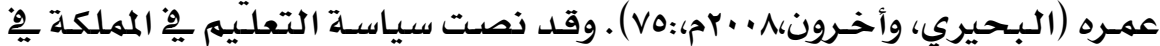

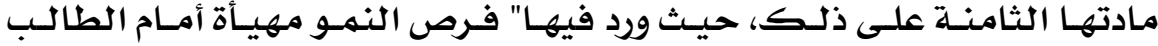

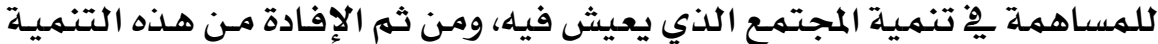

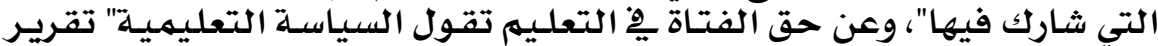

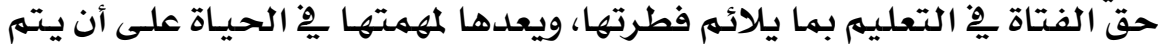

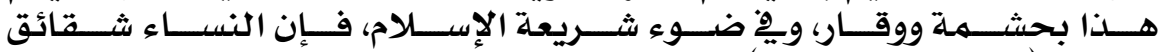

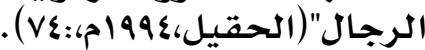

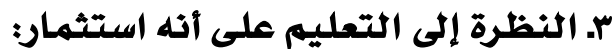

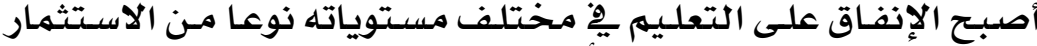

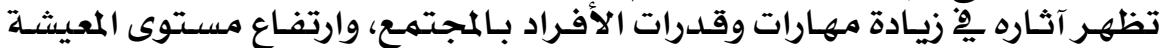

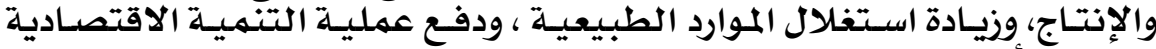

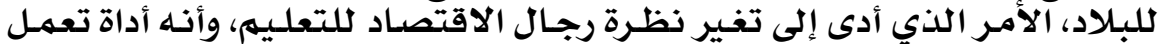

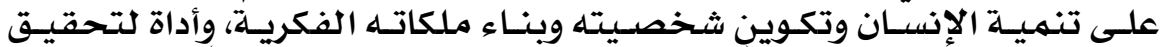

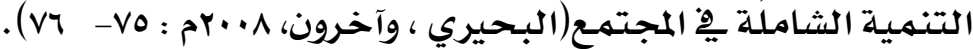

\section{0}




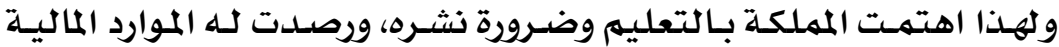

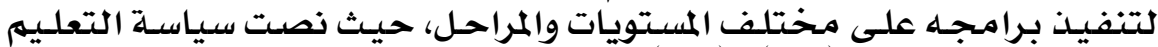

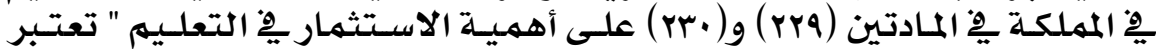

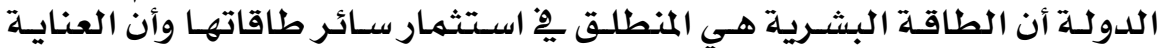

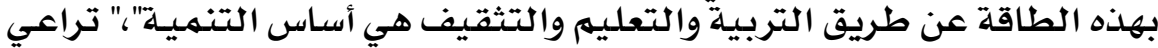

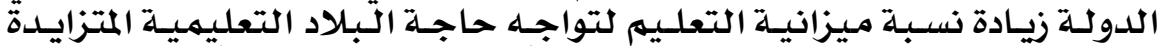

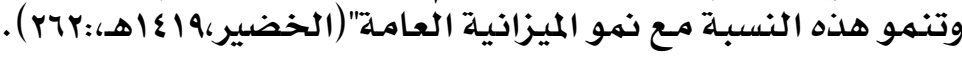

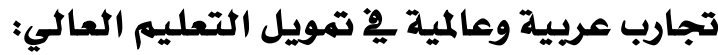

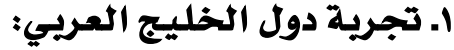

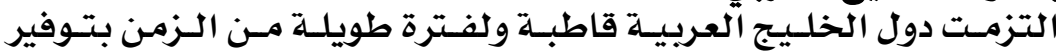

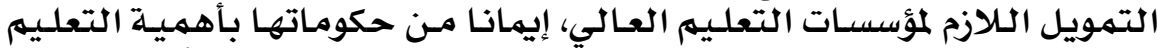

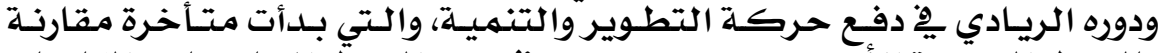

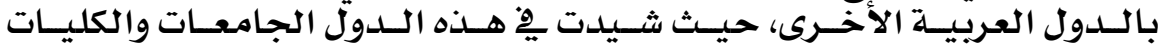

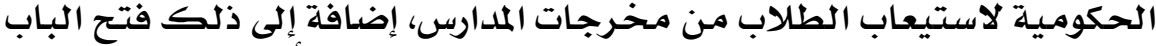

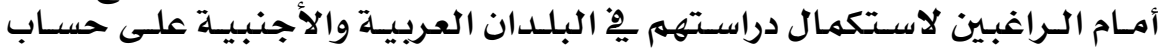

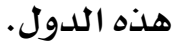

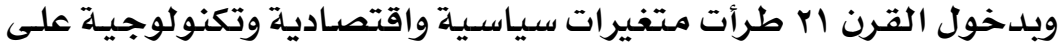

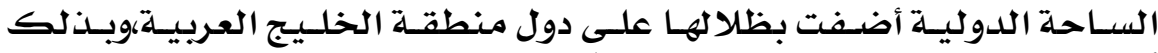

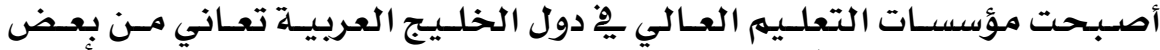

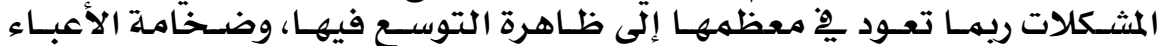

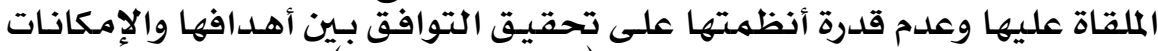

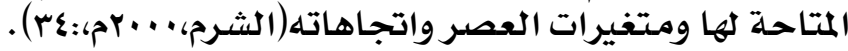

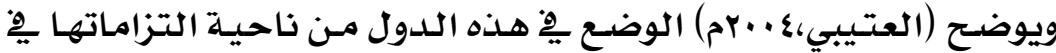

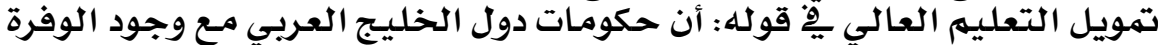

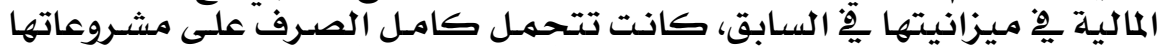

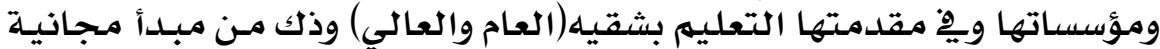

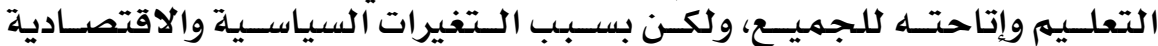

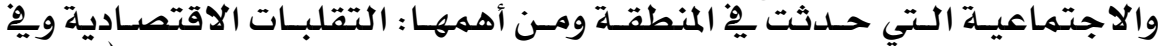

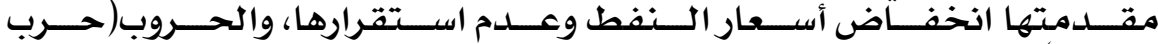

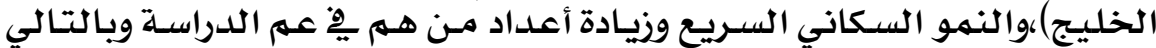

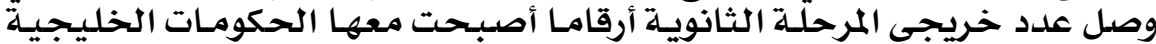

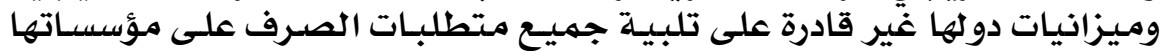

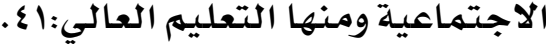

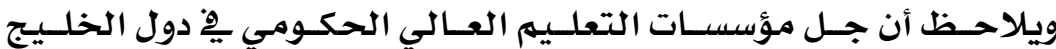

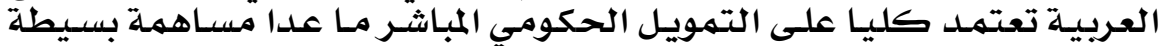

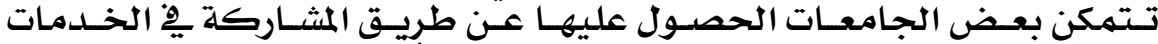

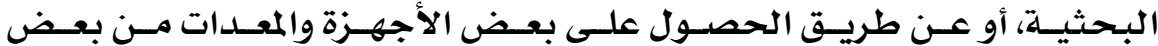
الشركات المرموقة أوعن.

\section{7}




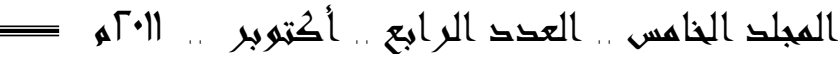

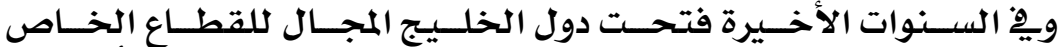

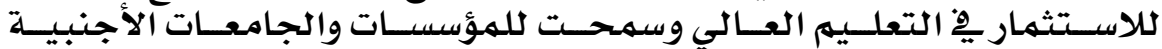

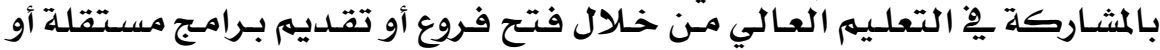

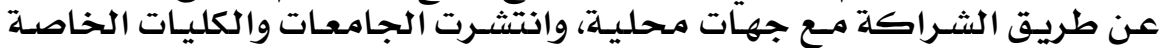

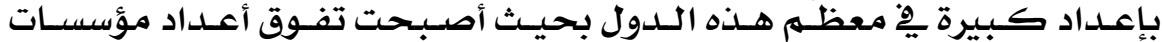

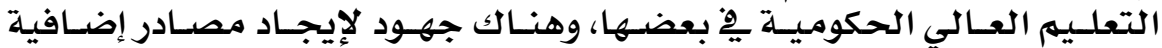

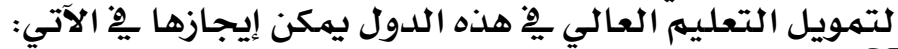

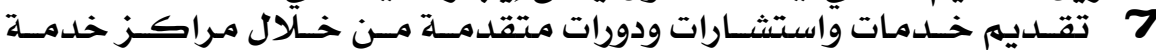

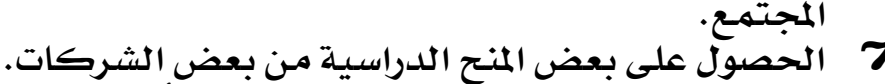

$$
\begin{aligned}
& 7
\end{aligned}
$$

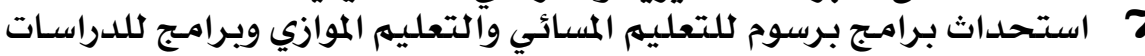

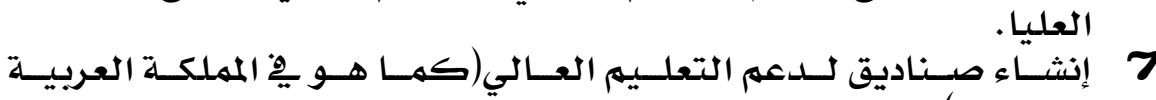

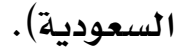
7 الحصول على تهويل للبحوث والمثاريـع العلمية.

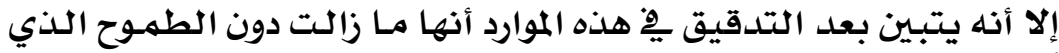

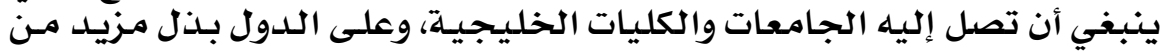

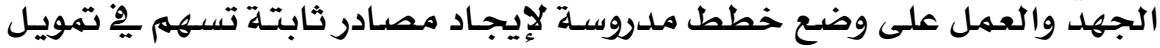

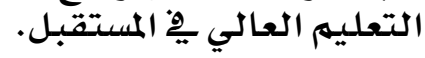

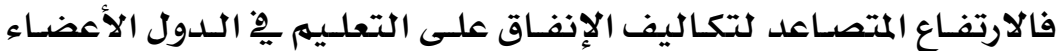

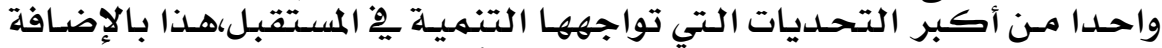

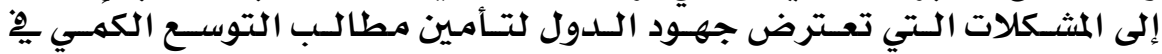

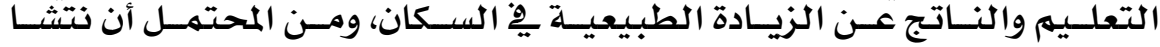

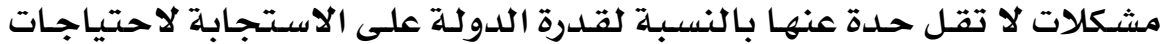

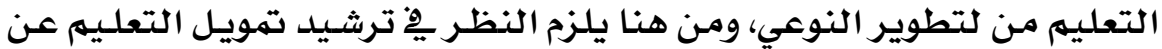

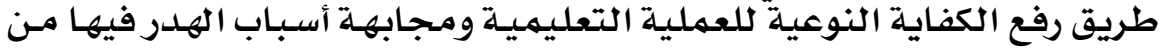

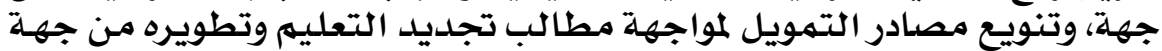

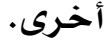

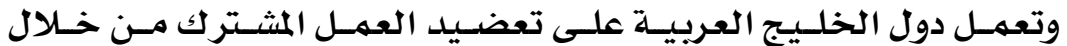

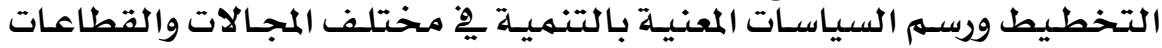

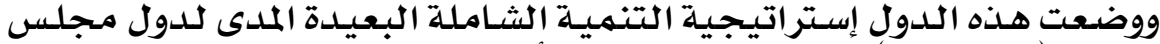

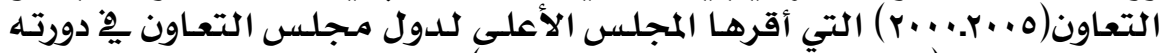

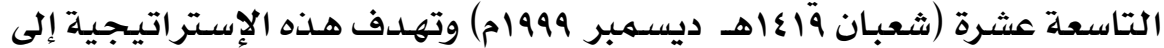

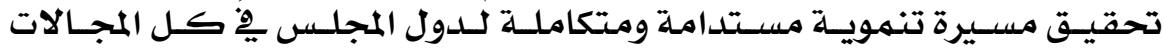

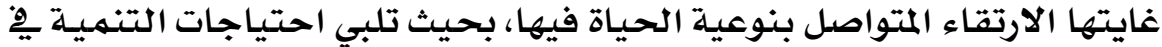

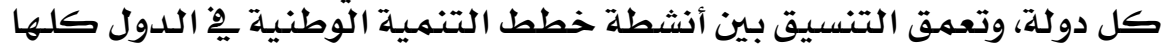

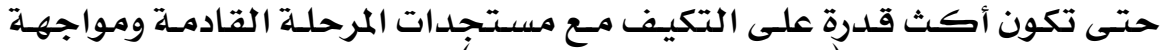

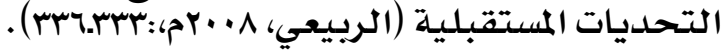

\section{q1V}




\section{r. تجرية المملكة الأردثية الهاشمية:}

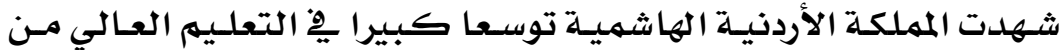

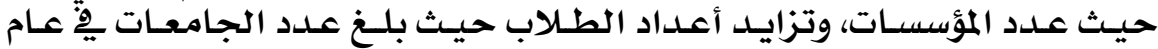

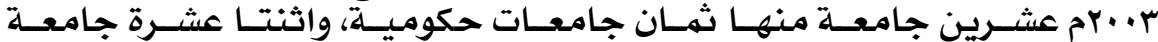

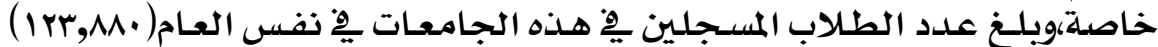

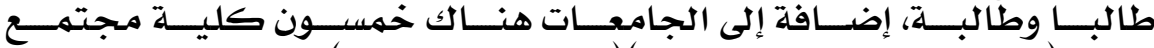

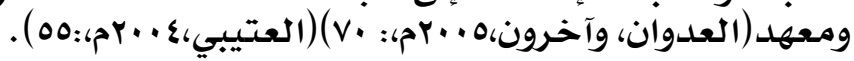

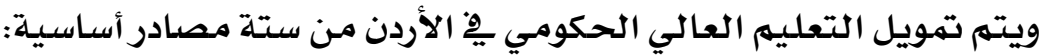

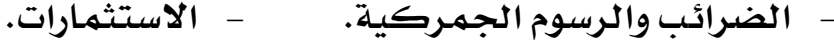

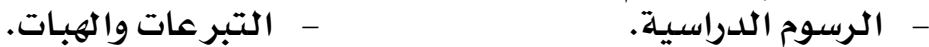

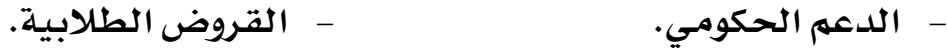

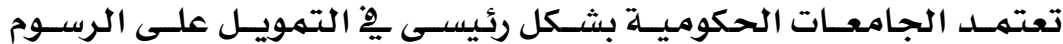

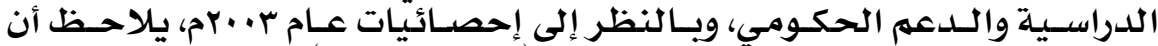

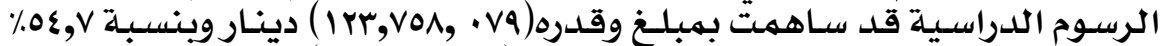

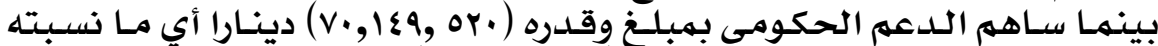

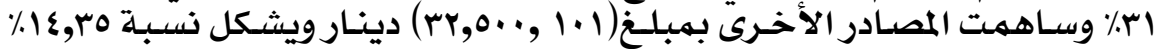

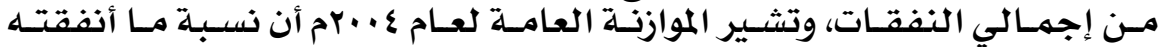

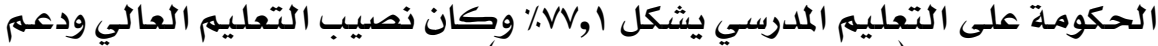

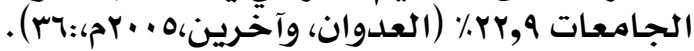

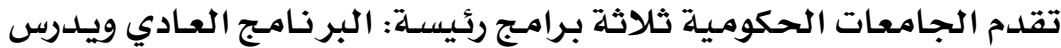

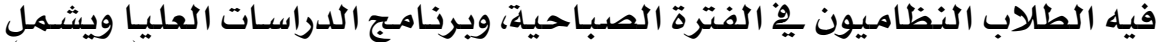

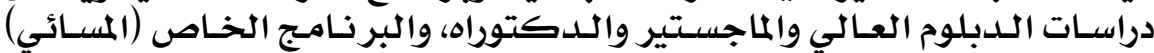
وينقسهم إلى ثلاثة فروع: الديات

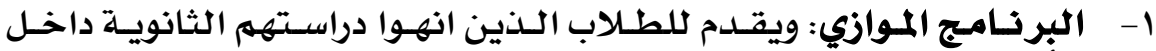

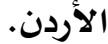

r- البرنامج الدولي: ويقدم للطلاب غير الأردنيين والطلاب الأردنيين الذين الذين

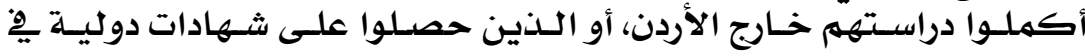
مستوى المرحلة الثانوية.

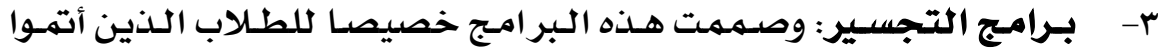

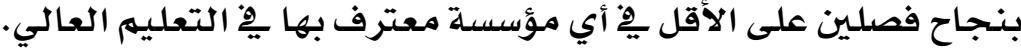

وتعاني الجامعات الحكومية ِِّ الأردن مـن بعض المشكلات من أهمها : 7 7

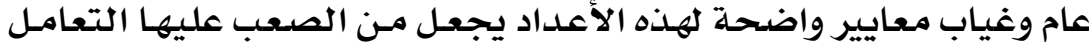
مع الكثير من القضايا ومنها تحديد التهايد التهويل الكاف لتفطية التفية النفقات.

\section{$91 \wedge$}




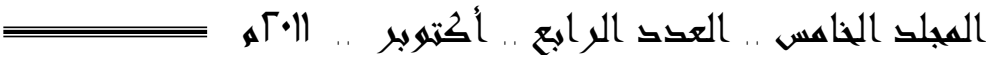

7 تفــاوت قيمـة اللدعم الحكومي مـن ســـة لأخـر أدى إلى صعوبة وجـود خطـة

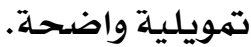

7

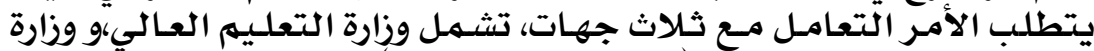

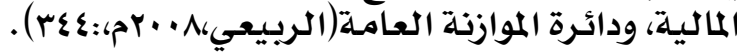

\section{r- تجرية المملكة المتحلدة(بريطانيا):}

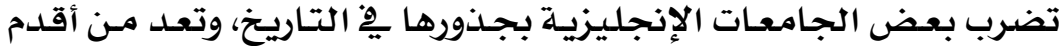

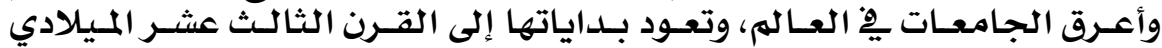

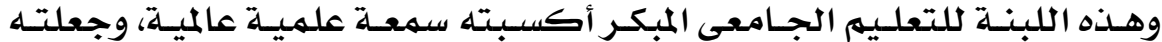

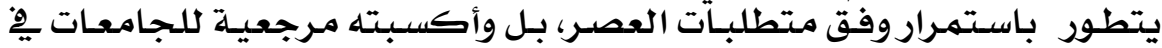

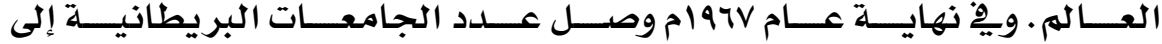

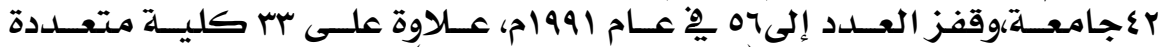

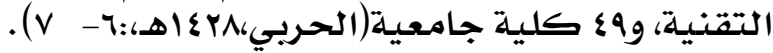

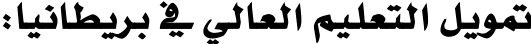

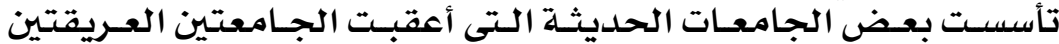

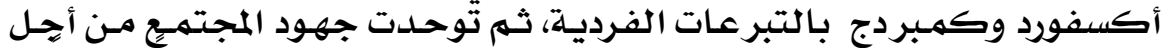

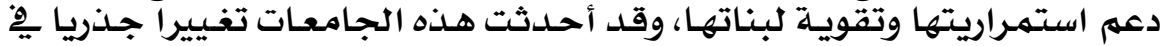

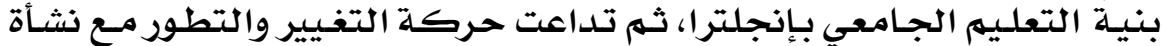

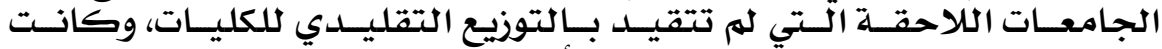

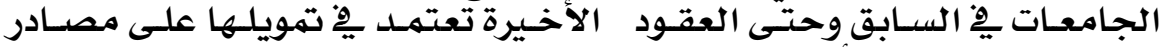

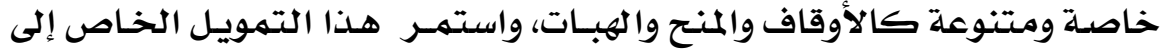

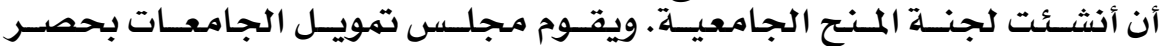

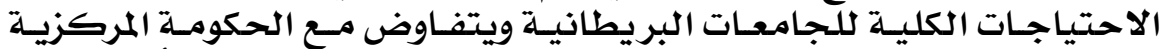

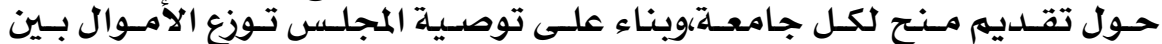

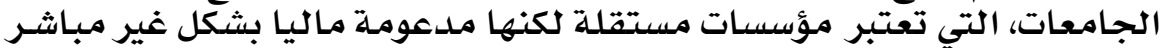

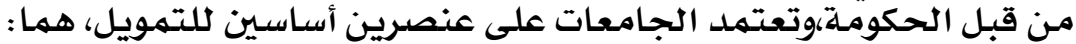

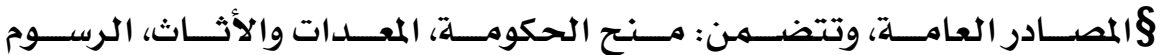

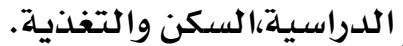

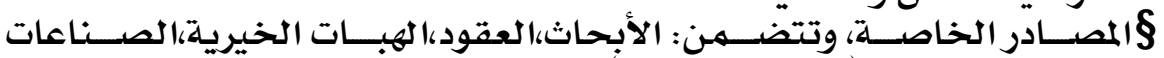

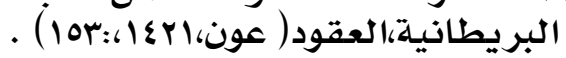

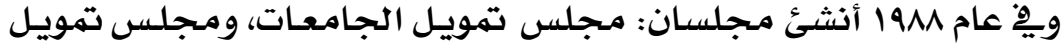

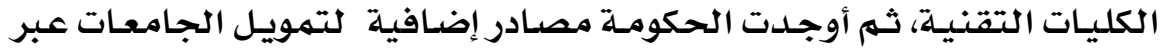

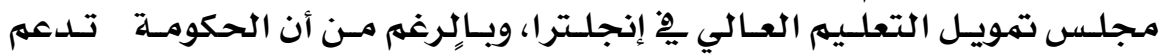

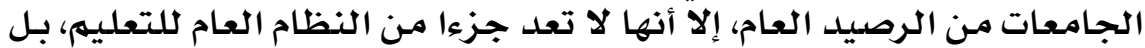

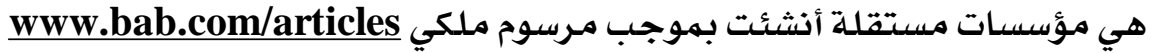

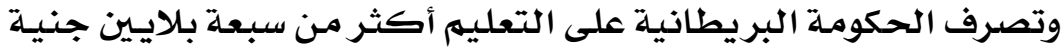

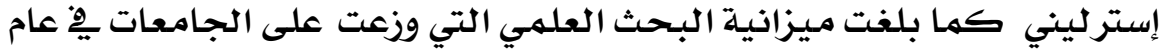

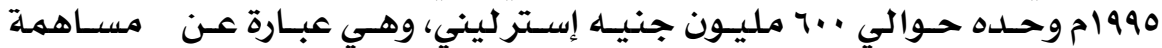

\section{9}




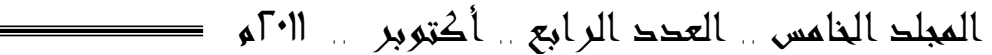

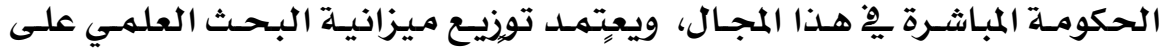

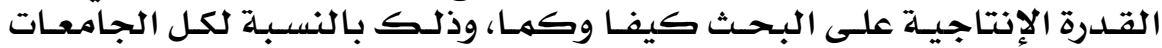

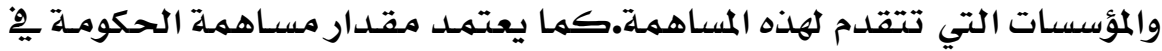

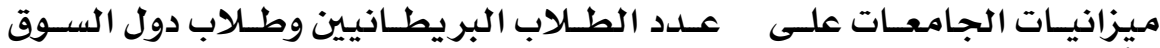
الأوروبية.

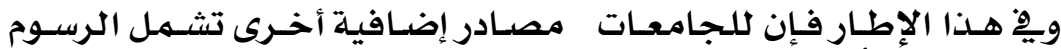

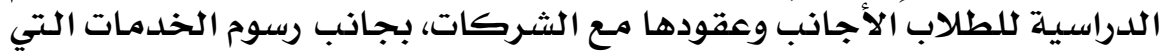

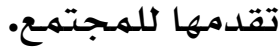

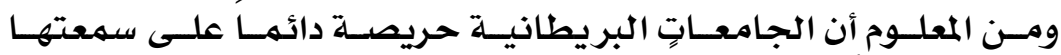

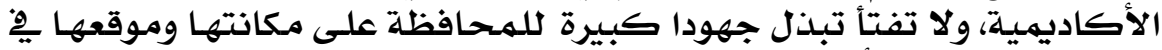

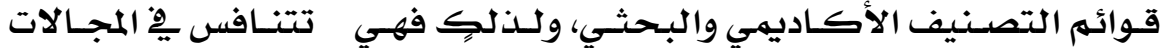

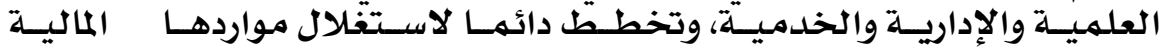

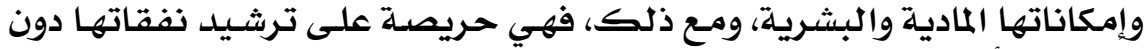

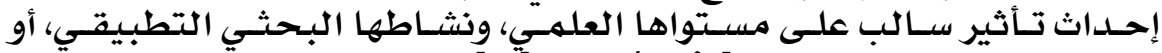
بضعف قدرتها التدريسية.

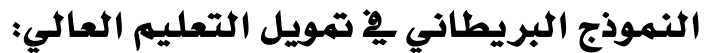

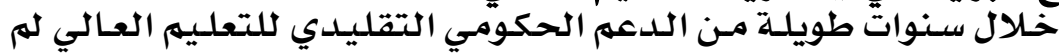

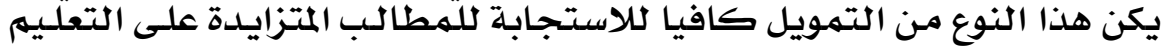

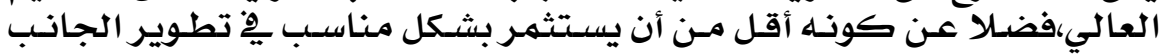
النوعي للتعليهم العالي. العني.

وظلت المملكة المتحدة لسنوات طويلة تبـحث عن آليـة لتتمككن مـن تجـاوز

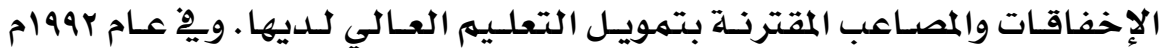

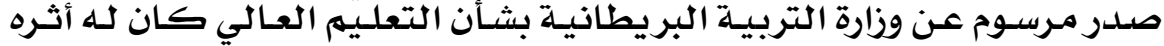

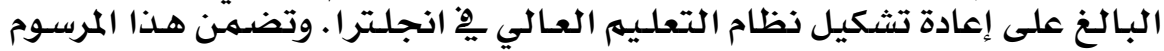
قرارا بإنشاء مجلس التهادة تشكيل نظام التعلعيم العالي.

الأهداف الرئيسة لإنشاء مجلس تمويل للتعليم العالي ببريطانيا:

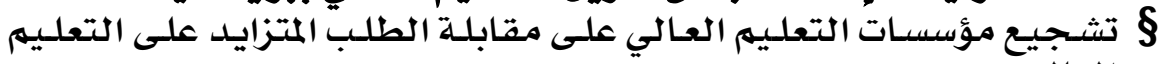

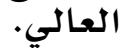

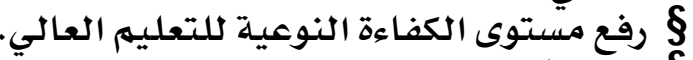

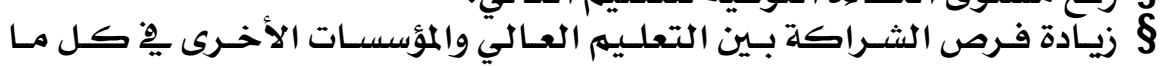

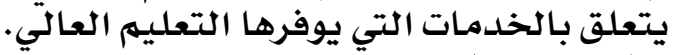

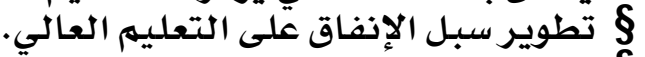

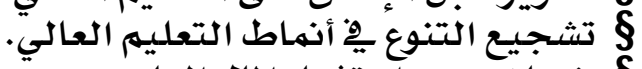

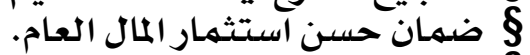

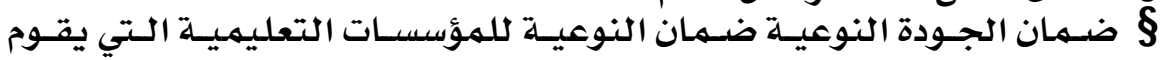

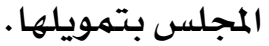
ß تشجيع الجامعات لتعديل مساراتها نحو الوجهة الصحيحة .

\section{QY.}


=

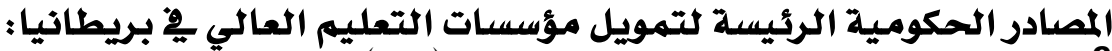

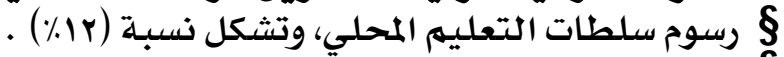

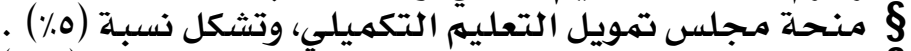

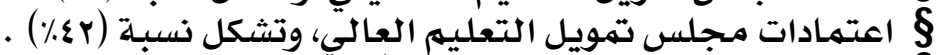

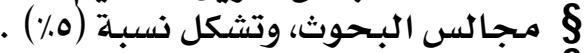

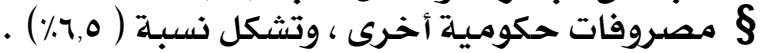

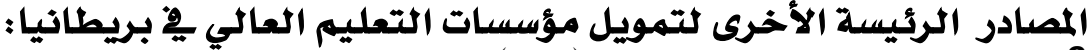

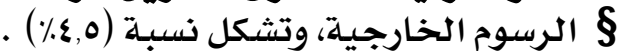

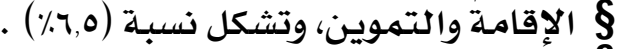

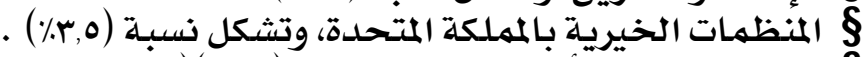

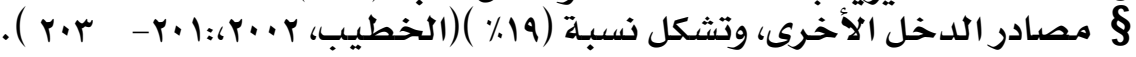

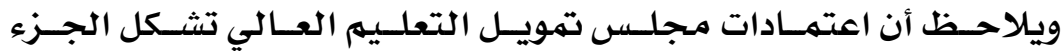

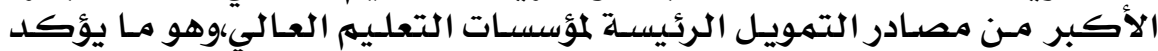

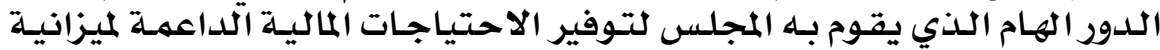

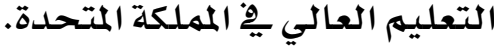

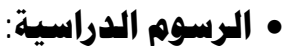

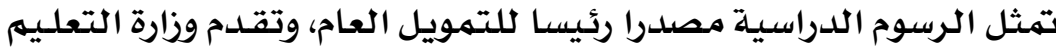

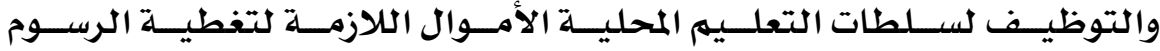

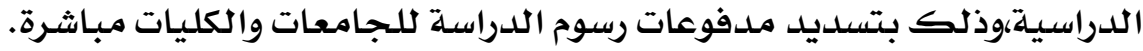

الاعتمادات المالية المخصصة للتدريس والبحوث:

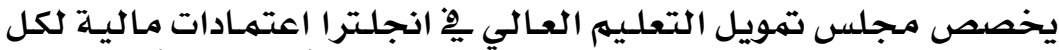

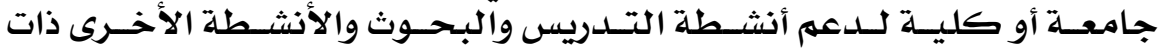

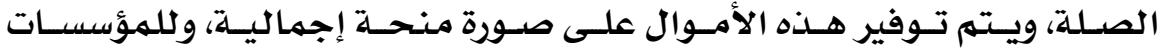

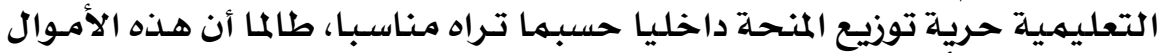

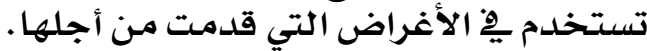

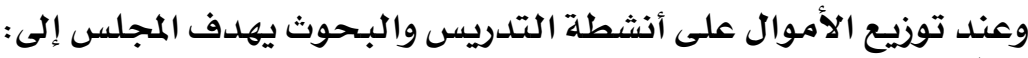

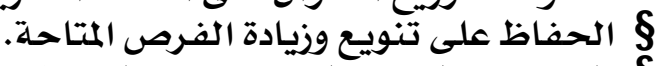

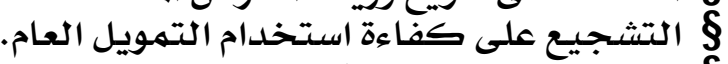

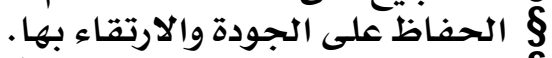

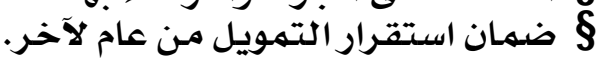

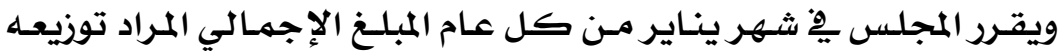

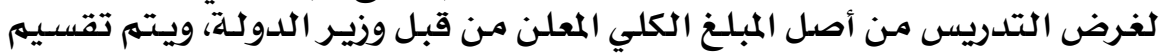

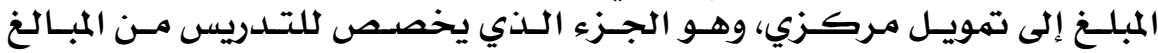

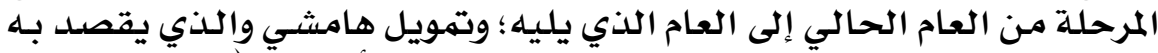

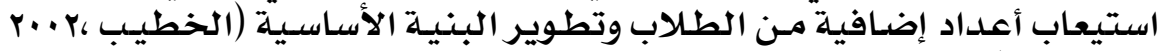

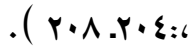

\section{q Y 1}




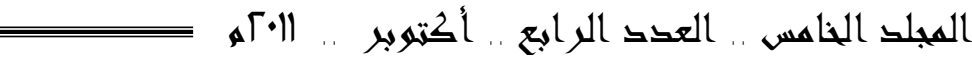

تحسين جودة التعليم العالي :

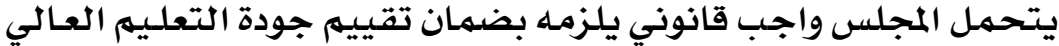

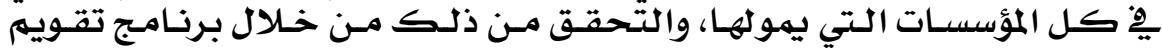

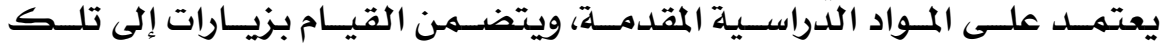

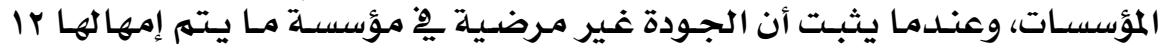

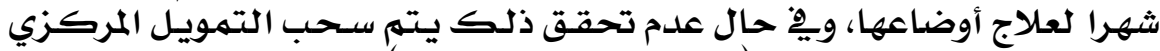

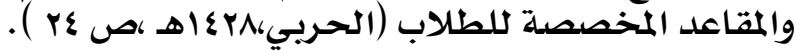

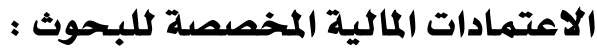

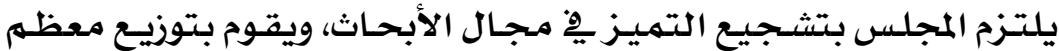

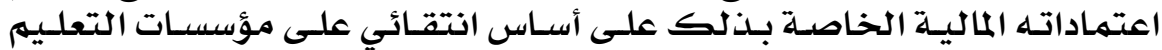

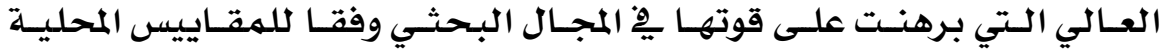

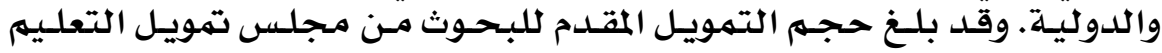

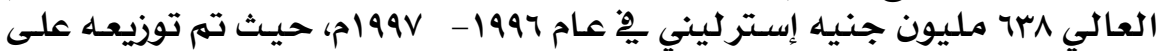

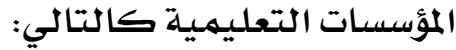

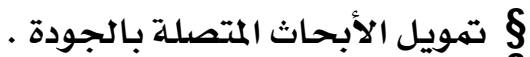

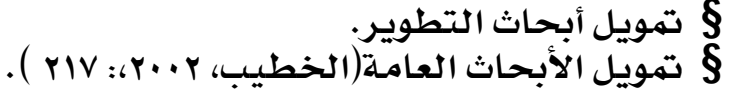

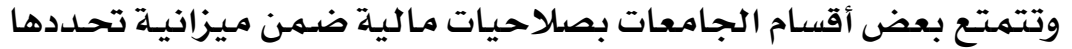

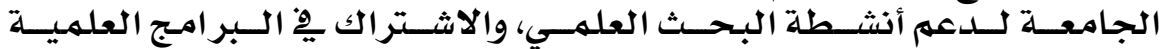

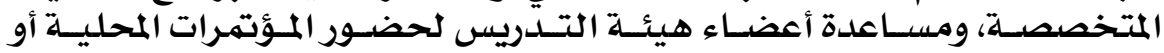

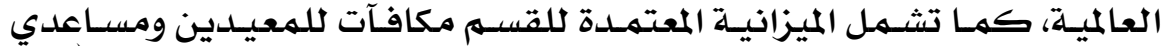

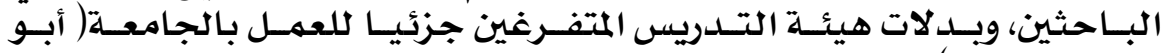

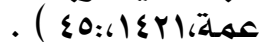

\section{تجرية المملكة المتحلدة فِ تمويل التعليه ببدائل فير حكومية:}

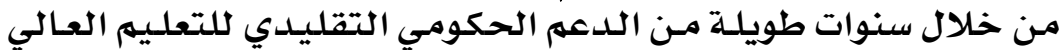

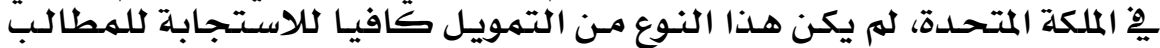

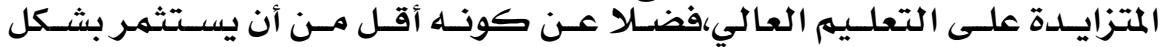

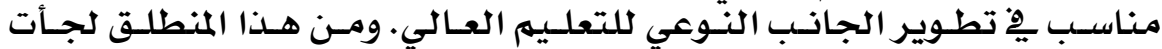

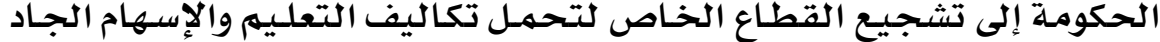

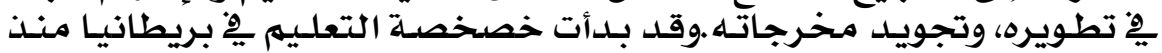

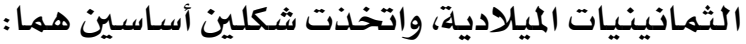

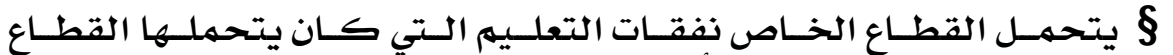

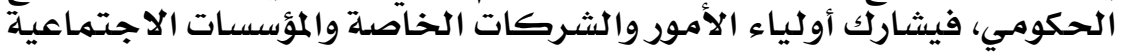

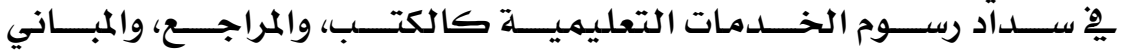
والتجهيزات،وغير ها من المهاريف.

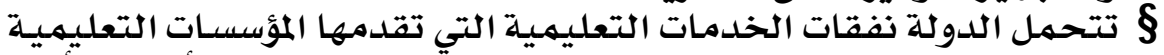

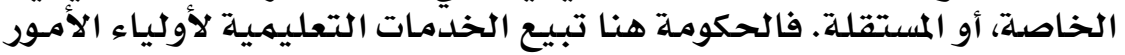

\section{QYY}




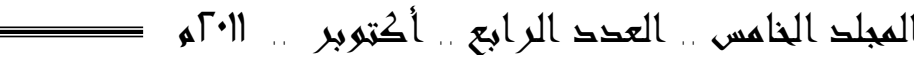

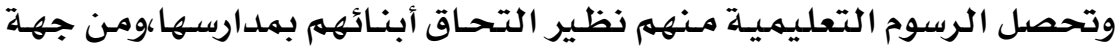

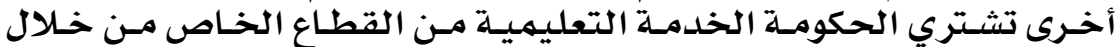

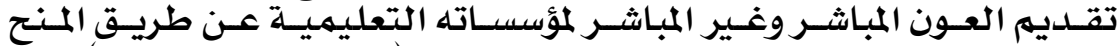

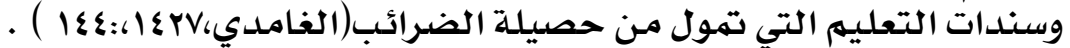

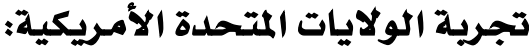

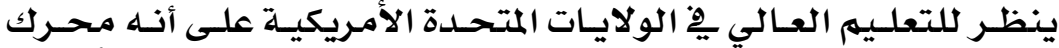

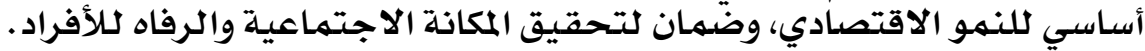

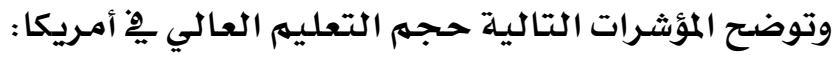

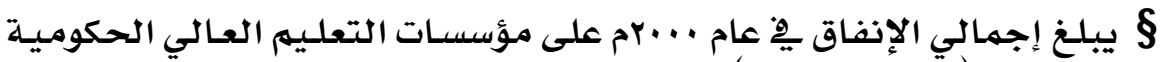

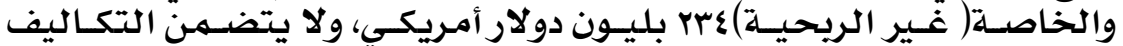

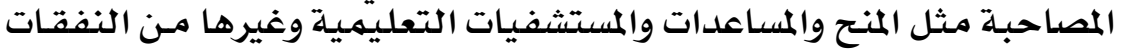

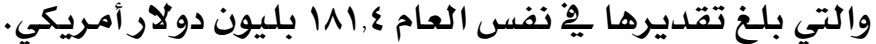

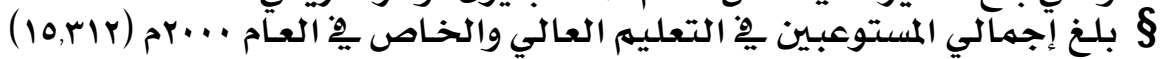

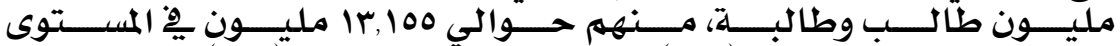

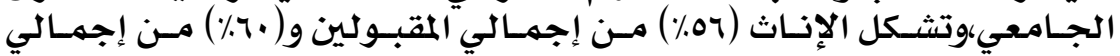
الطلاب يدرسون بنظام الدوام الكامل.

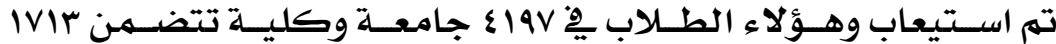

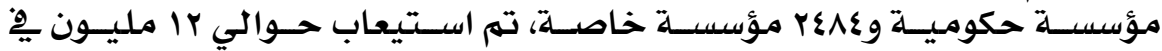

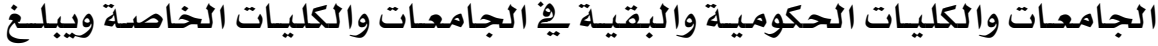

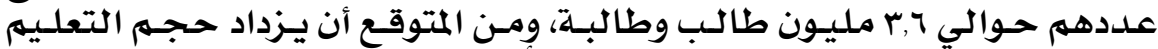

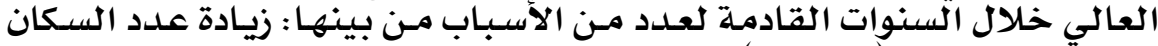

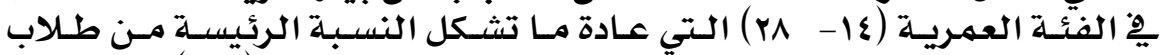

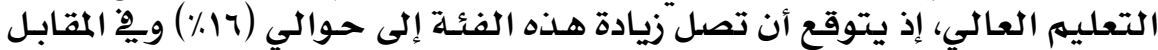

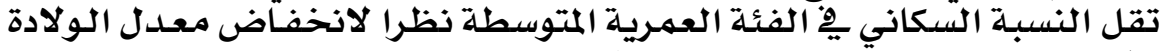

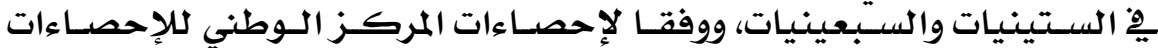

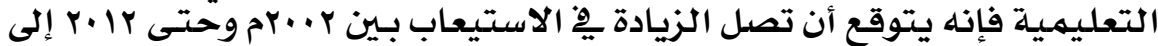

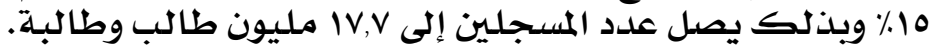

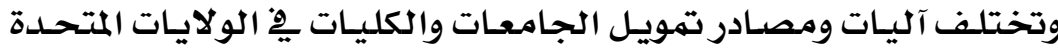
طبقا لبعض المحلددات منها:

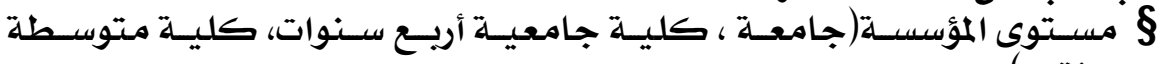
سنتين).

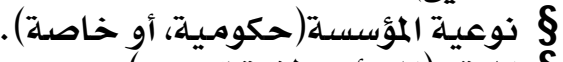
ß الموقع (إلى أي ولاية تنتتهي).

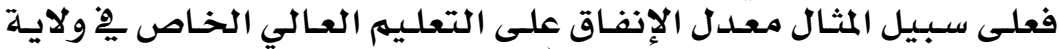

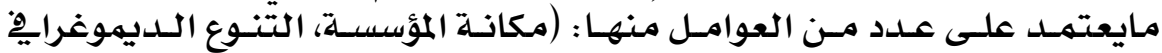

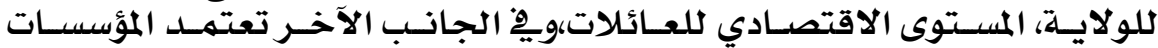

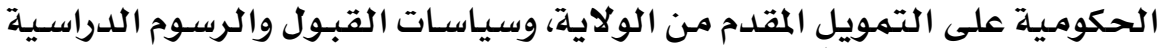
التي يسهم بها الطالب) التهويل.

\section{Yr}




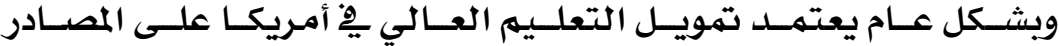
التقليدية الرئيسة الآتية:

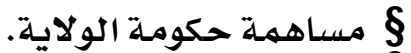

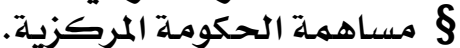

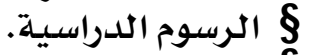

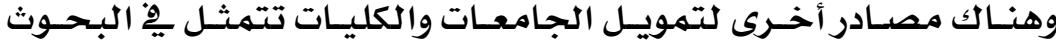

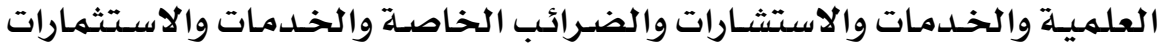

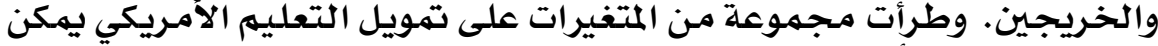

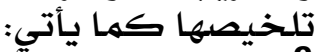

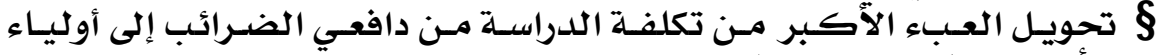

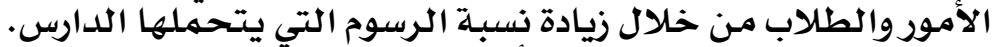

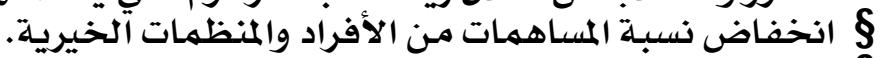

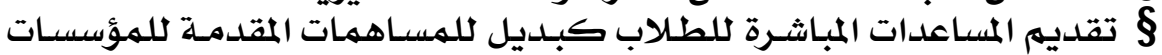
التعليمية.

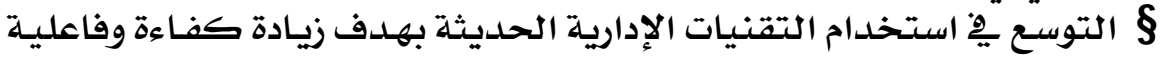

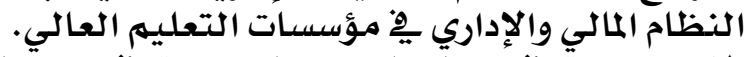

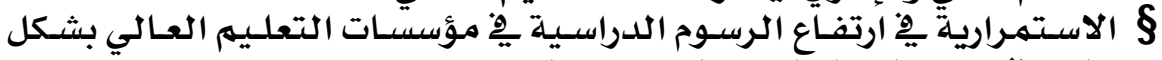

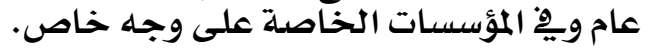

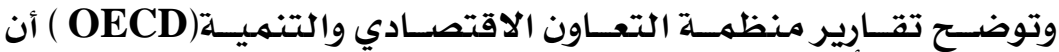

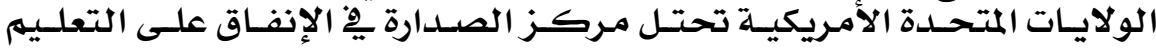

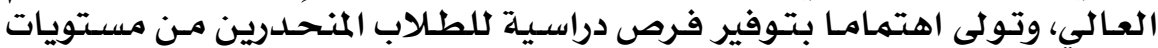

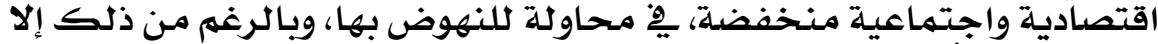

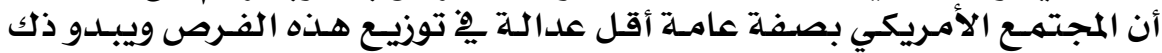

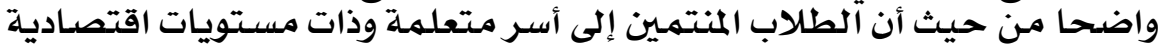

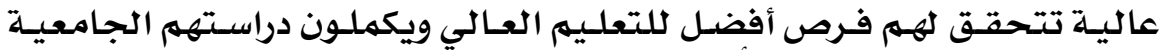

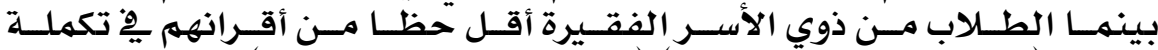

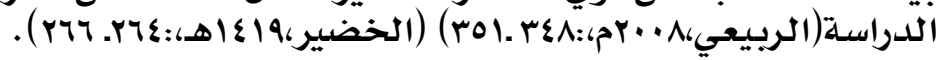

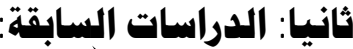

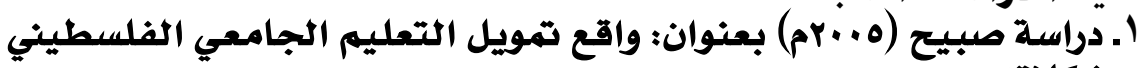

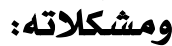

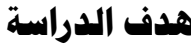

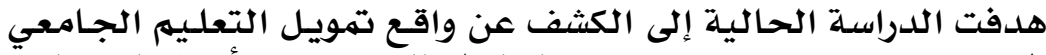

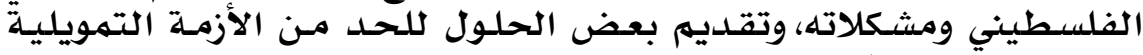
للجامعات ألفلسطينية ومثينها

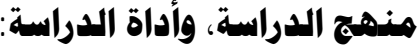

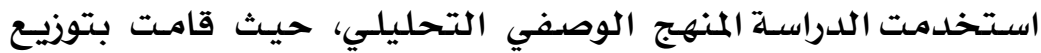

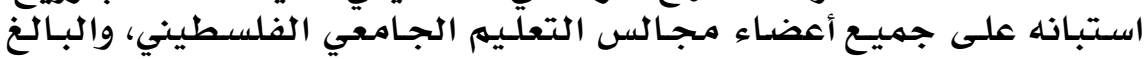

\section{QY}




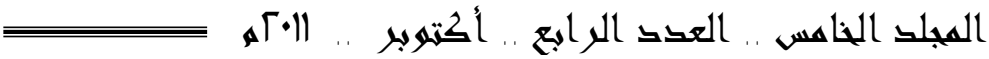

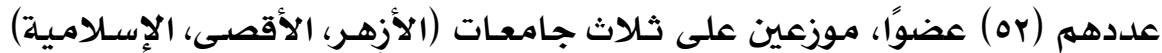

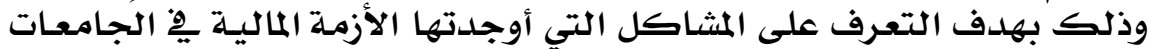

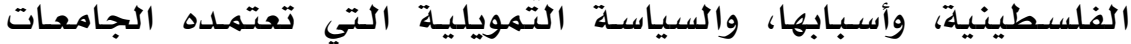
الفلسطينية.

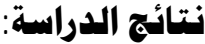

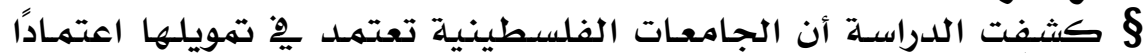

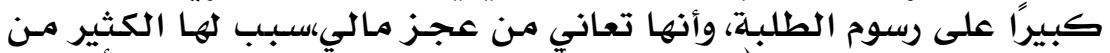

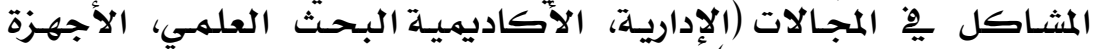

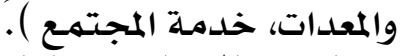

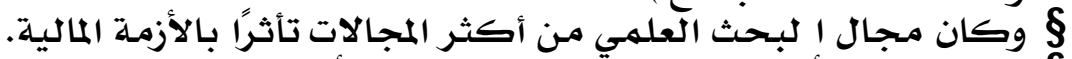

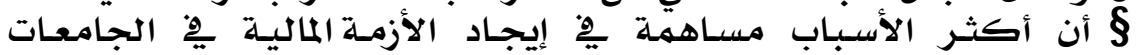

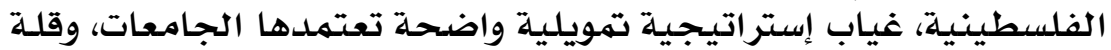

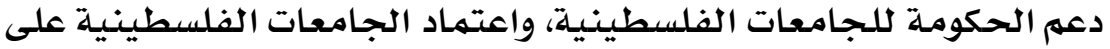

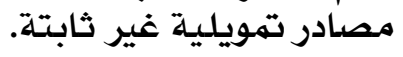

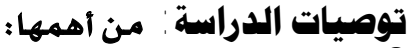
ضـرورة تفعيل دور وزارة التربيـة والتعليهم فِ تمويـل التعليهم الجـامعي الفلسطيني.

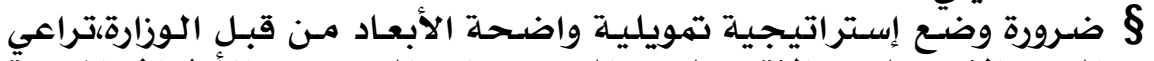

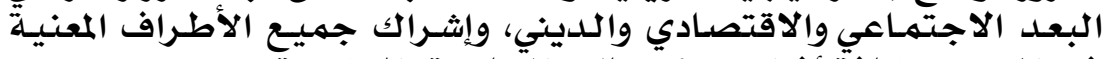

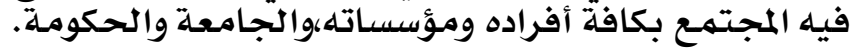

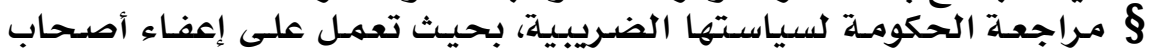

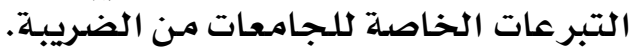

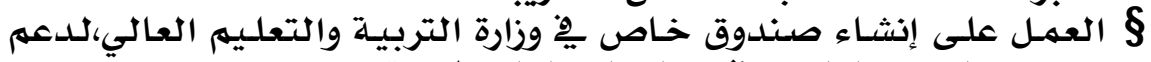

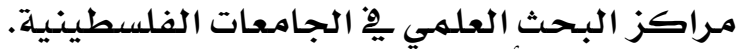

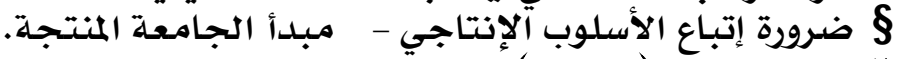

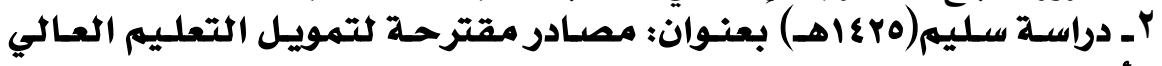

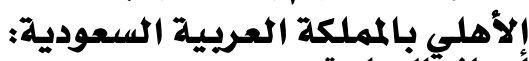
أهدافت"الندراسة : المهيكة

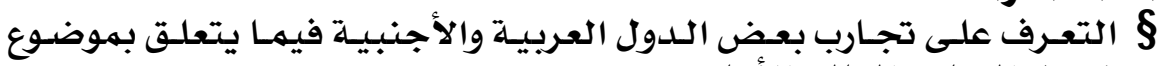

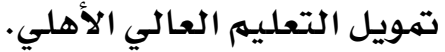

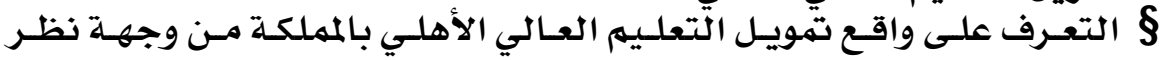

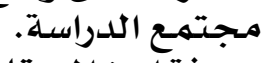

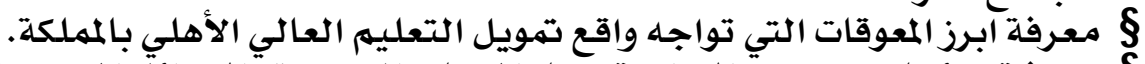

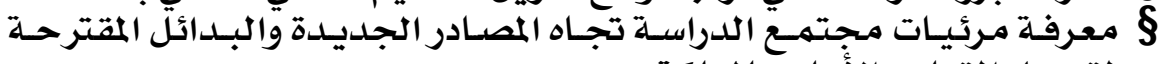

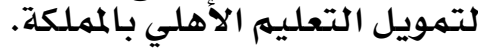

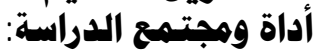

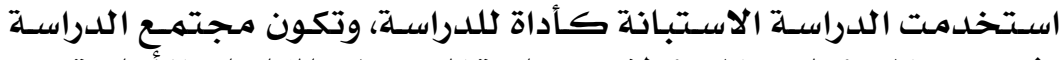

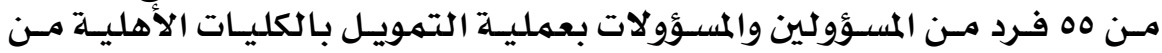

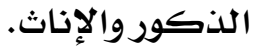

\section{QY०}




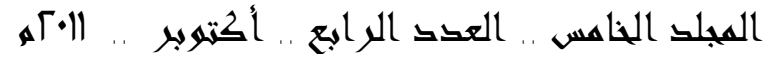

نتائج الدراسة: من أهمها:

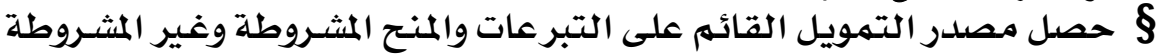

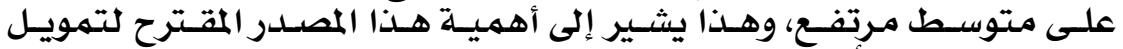

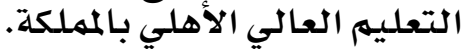

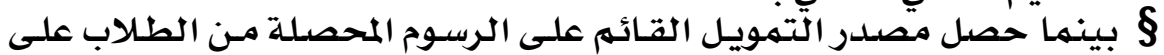

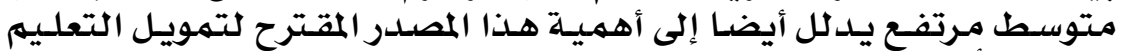

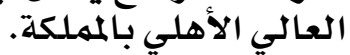

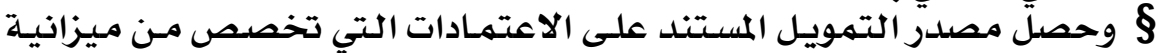

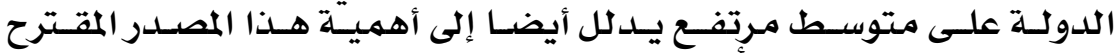

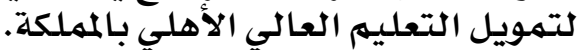

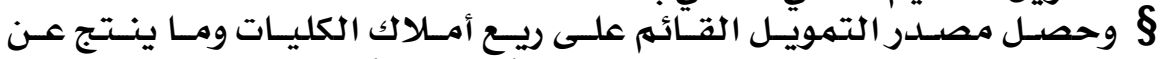

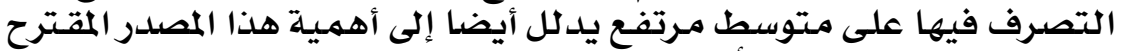

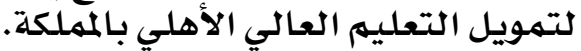

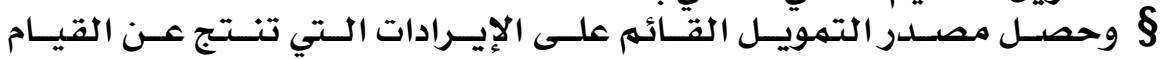

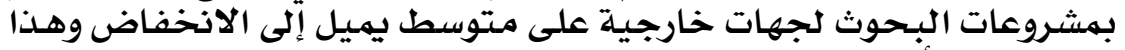

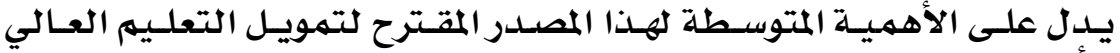
الأهلي بالمملكة الأهي.

\section{توصيات الدراسة: من أهمها:}

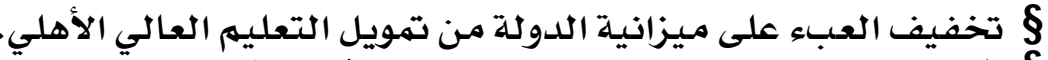

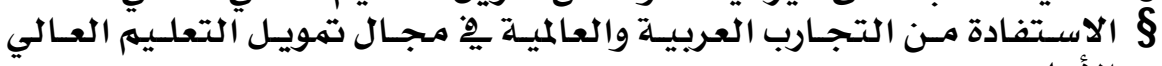

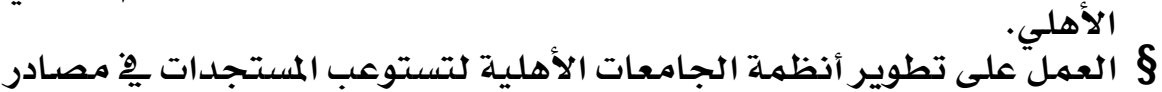

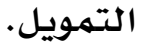

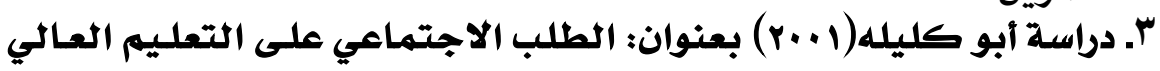

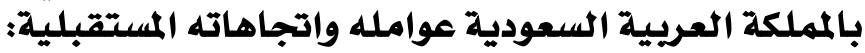

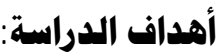

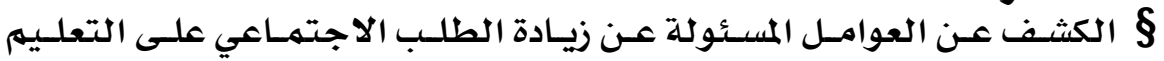

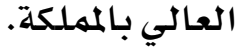

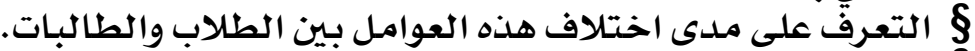

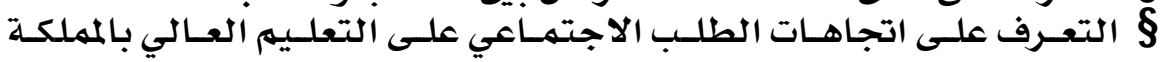

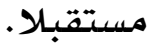
ß اقتراح التدابير والضمانات لمواجهة الطلب الاجتمهاعي على التعليم العـالي مِ في المستقبل.

\section{أداة الدراسة وهجتمع الدراسة :}

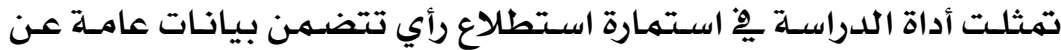

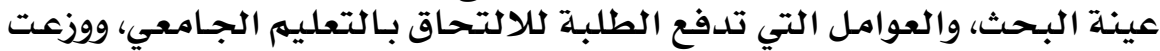

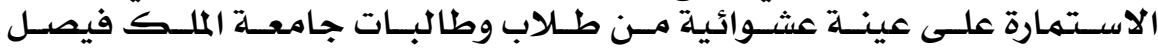

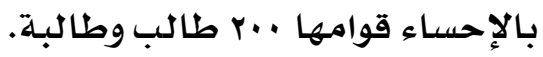

\section{Y 7}


المجلد الخاهس .. العقد الرايع .. أكتهوبر .. الآم

نتائج الدراسة :

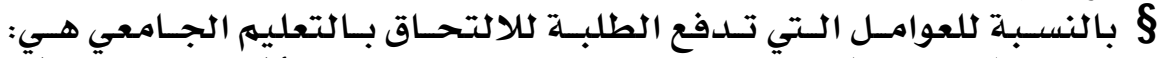

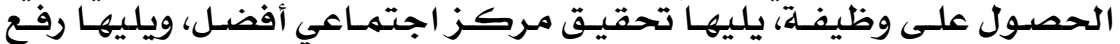

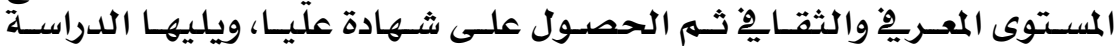

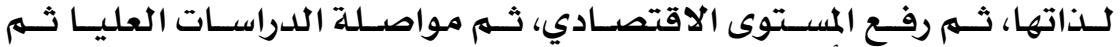

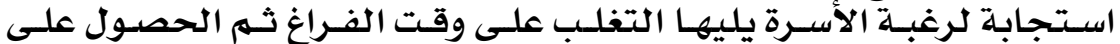

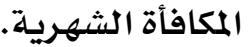

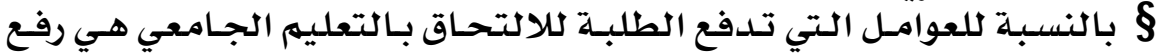

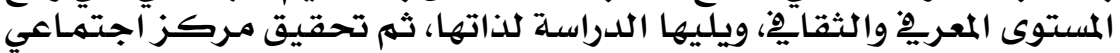

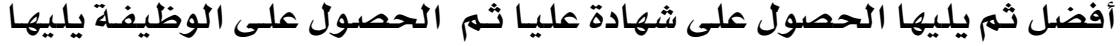

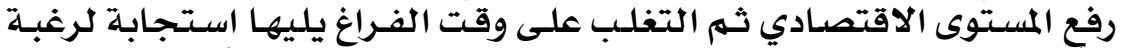

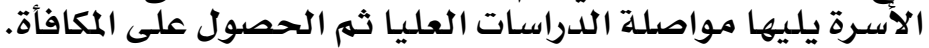

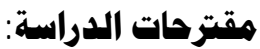

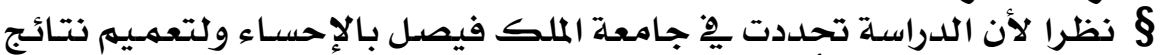

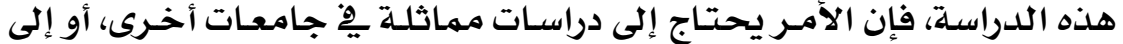

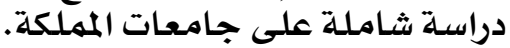

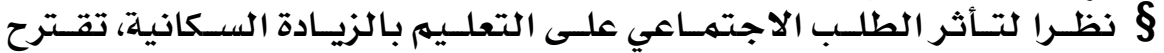

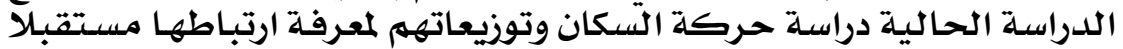

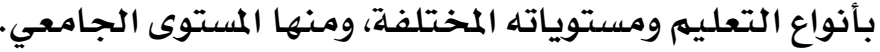

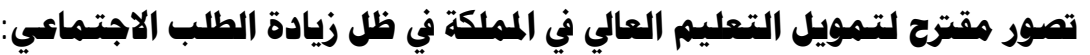

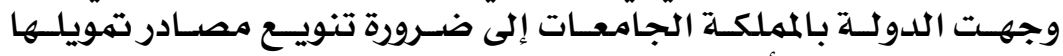

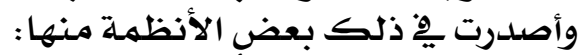

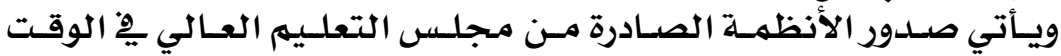

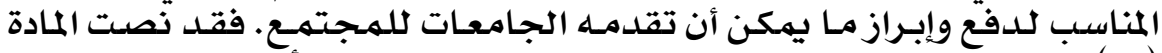

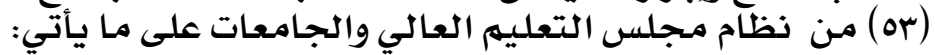

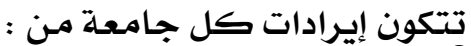

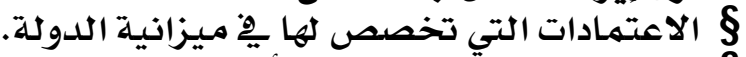

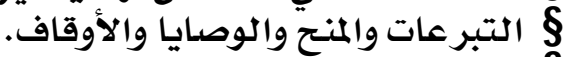

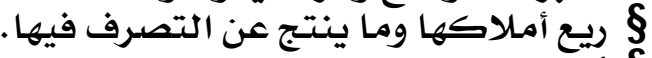

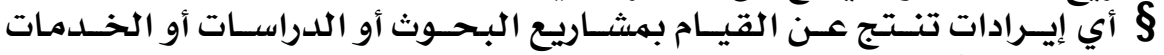

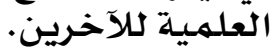

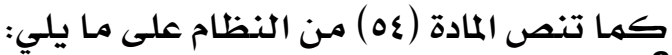

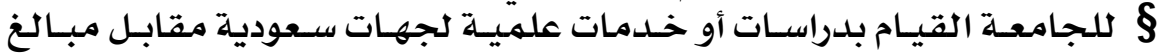

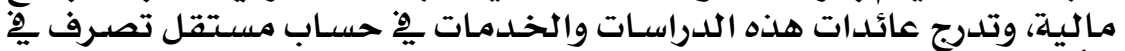

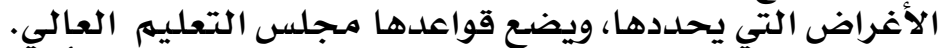

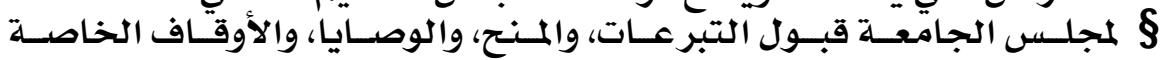

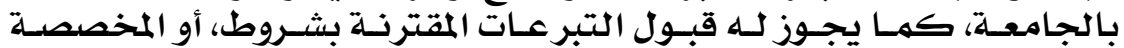

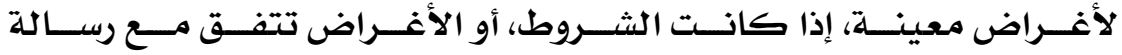

\section{QYV}

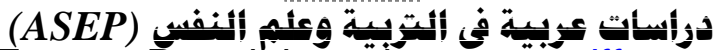




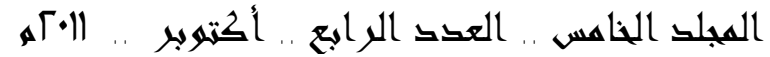

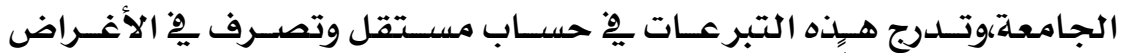

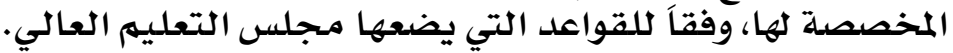

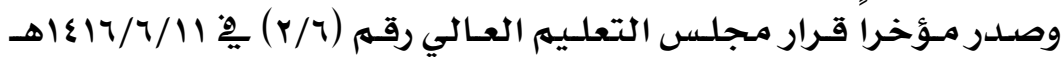

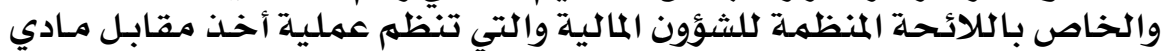

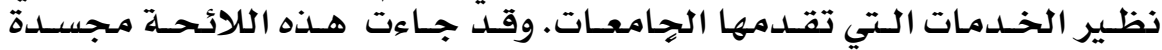

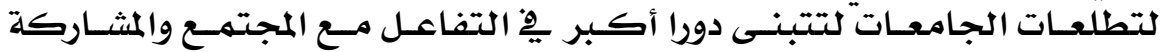

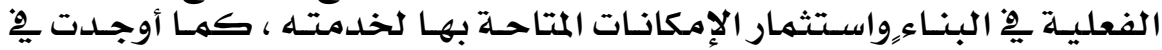

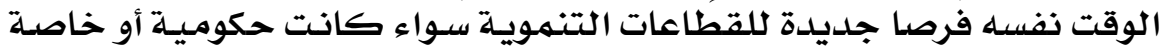

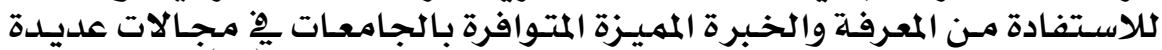

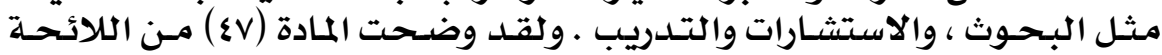

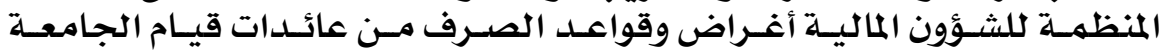

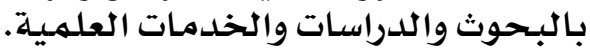

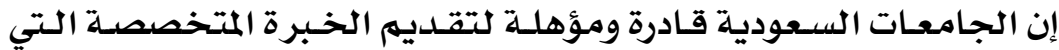

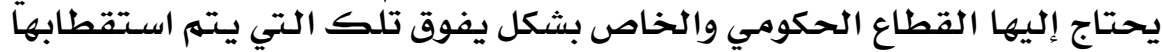

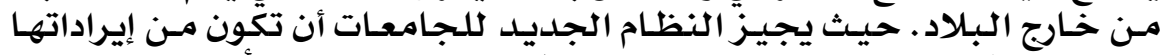

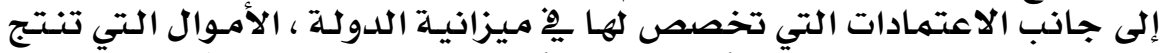

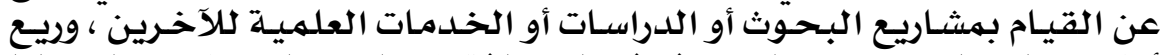

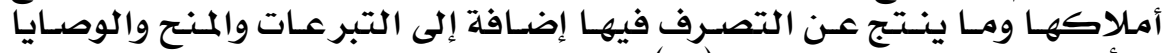

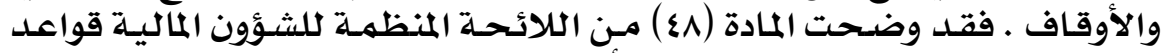

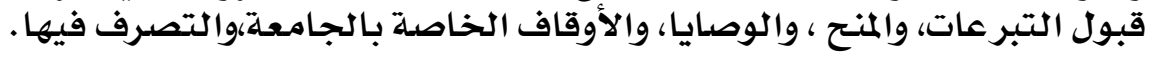

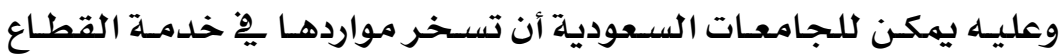

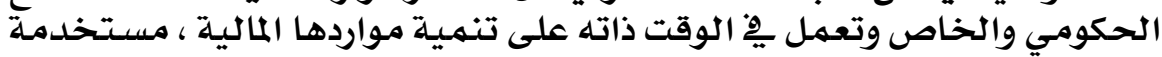

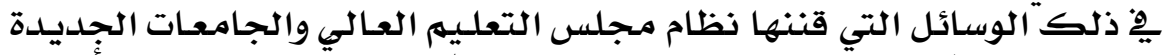

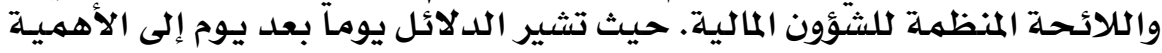

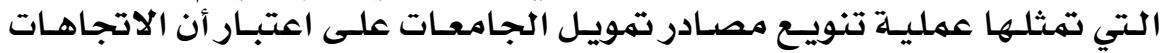

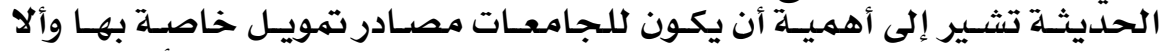

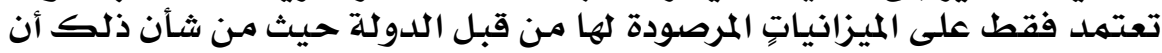

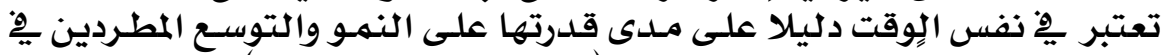

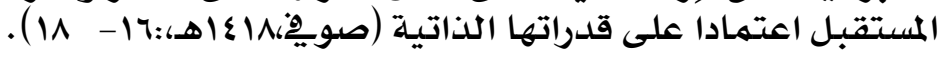

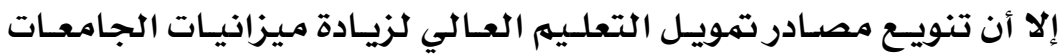

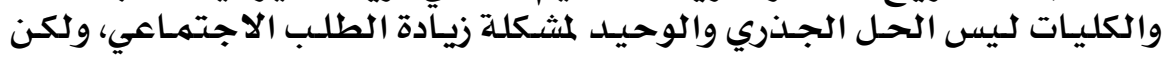

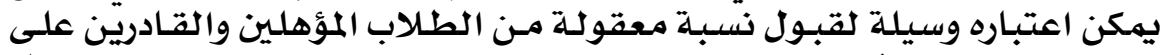

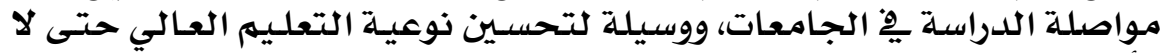

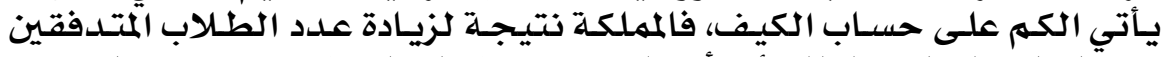

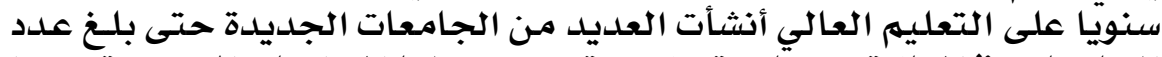

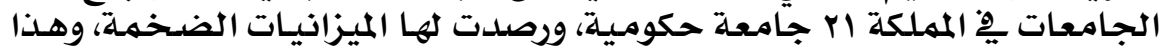

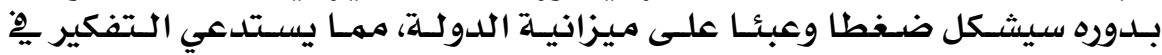

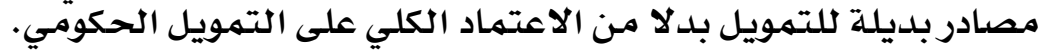

\section{Y}

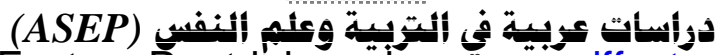




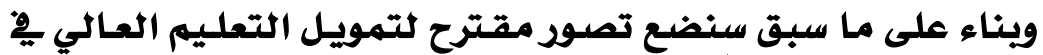

المملكة يٌْ ظل زيادة الطلب الاجتماعي:

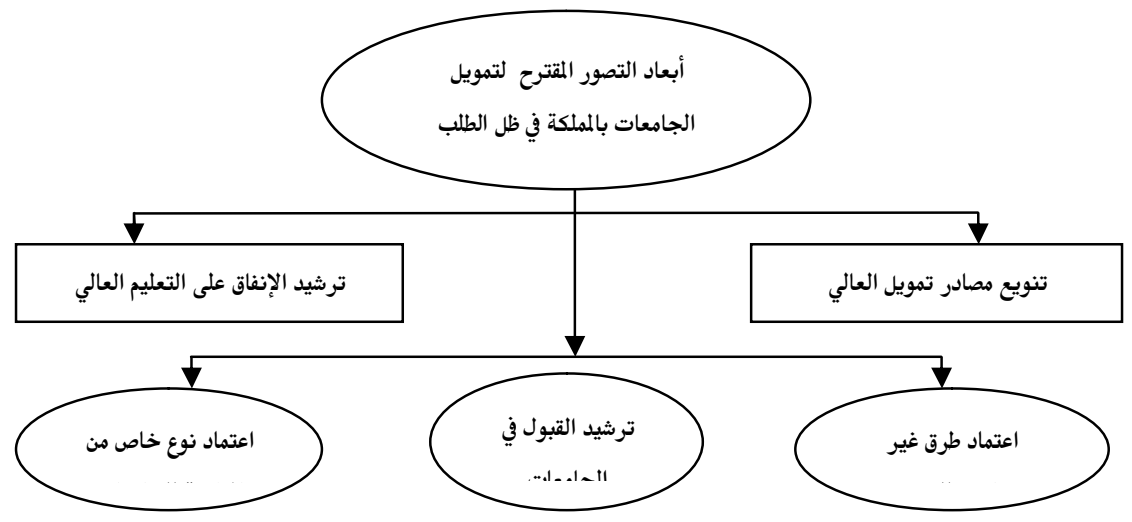

* البعد الأول : تنويع مصادر تمويل التعليم العالي:

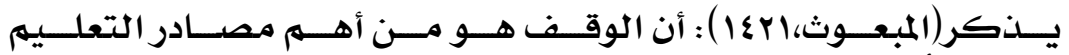

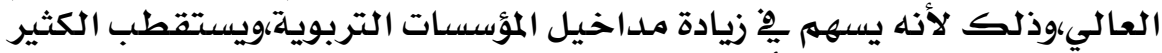

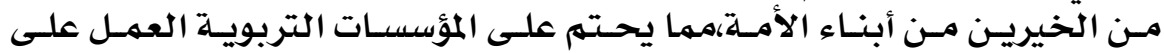

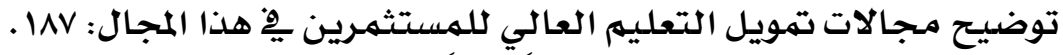

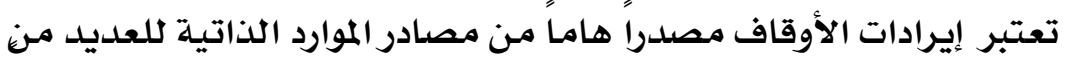

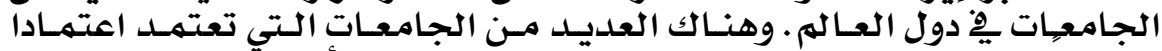

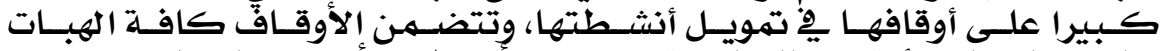

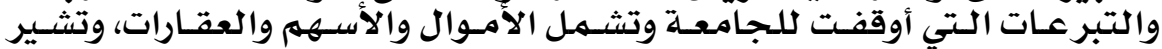

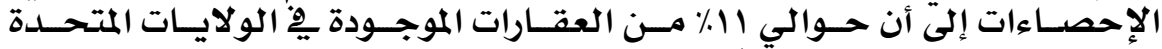

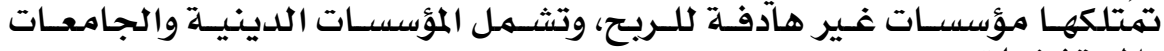

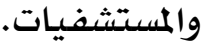
ويبين الجدلول رقم (ع) قائمة بالعشرة جامعات (يُ الولايات المتحدة) التي لديها أكبر

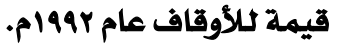

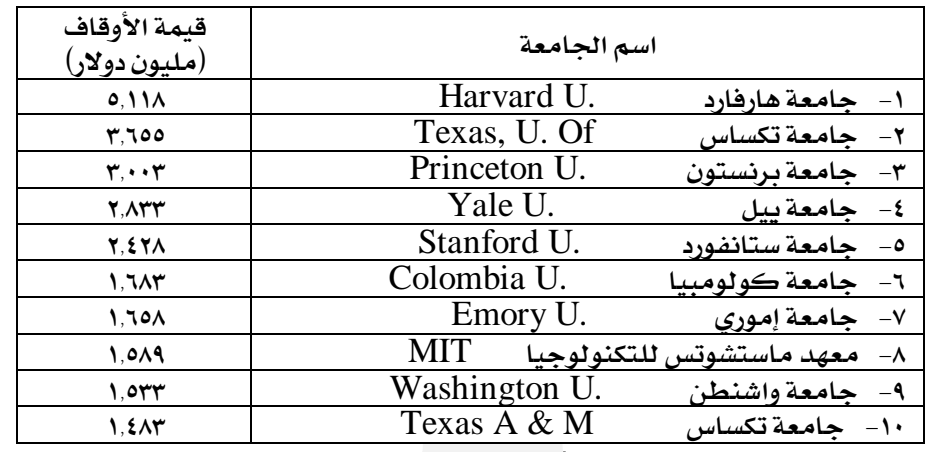

\section{Y 9}




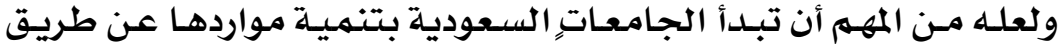

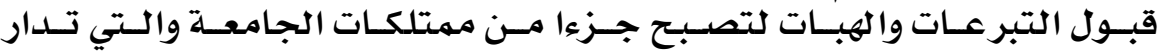

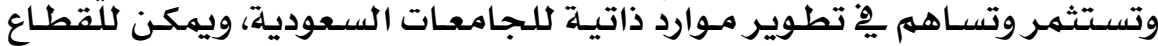

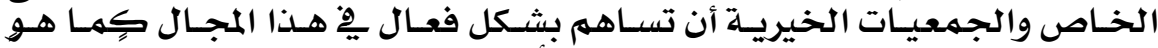

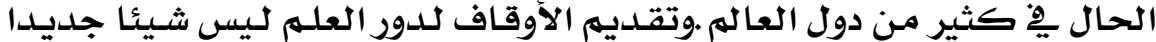

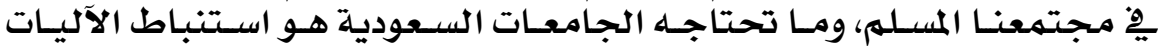

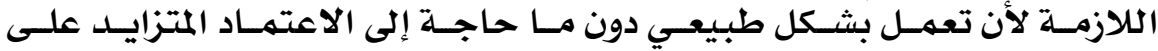

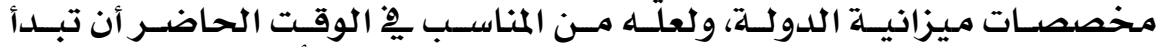

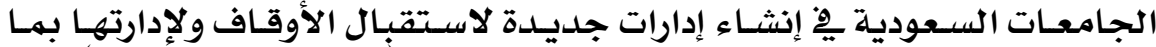

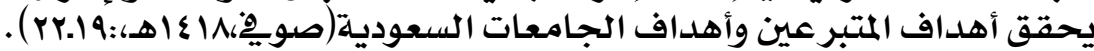

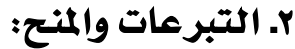

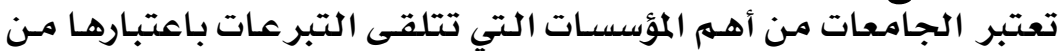

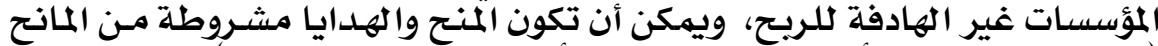

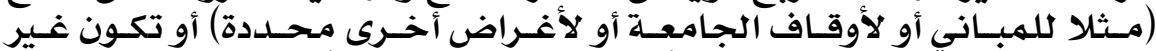

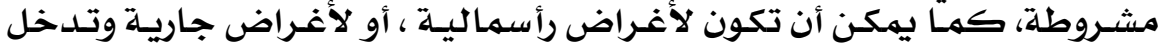

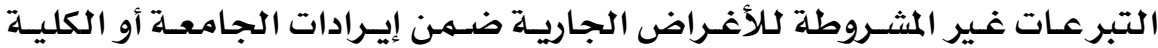

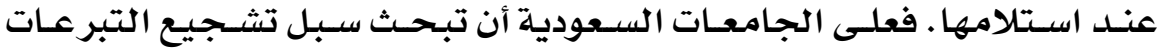

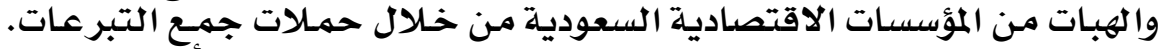

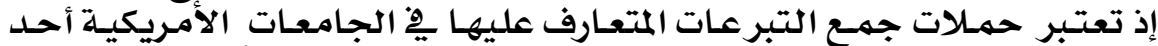

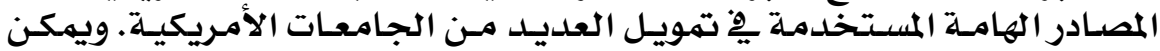

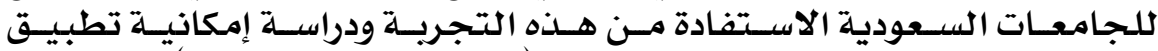

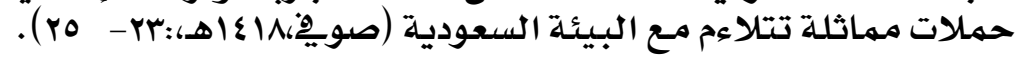

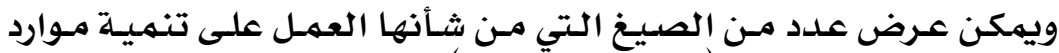

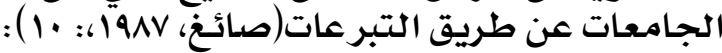

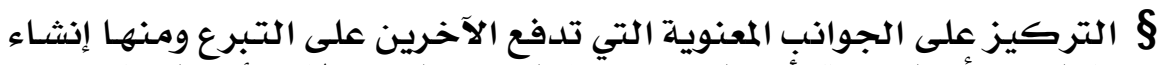

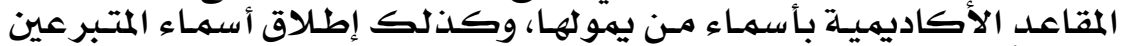

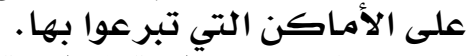

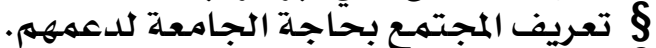

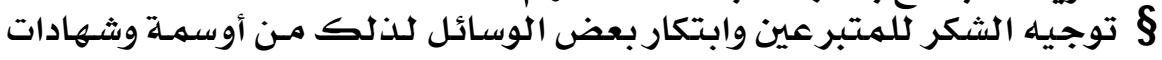
شكر. ß إنشاء صناديق للتبر عات تلبي حاجات المتبر التبر عين.

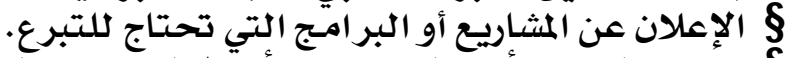

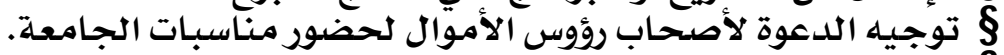

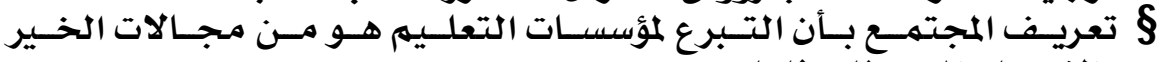

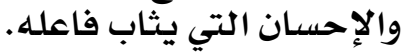

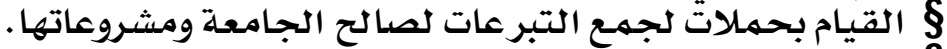

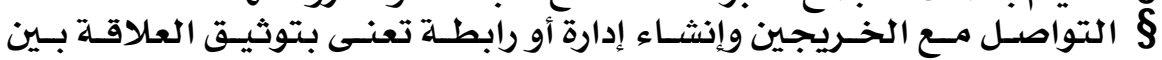
الخريجين والجامعة الخدئ. عرض الجامعلة لبعض المشاريع باعتبارها مشاريع وقفية تحتاج المساهمة.

\section{$9 \%$.}

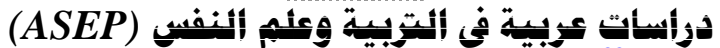




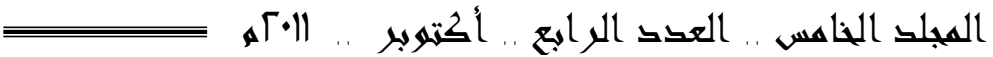

r. الإيرادات الناتجـة عن القيـام بمشـاريع البحـوث أو الدراسـات أو الخدمات

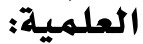

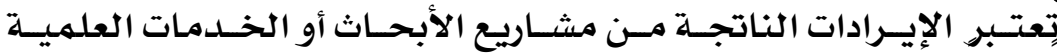

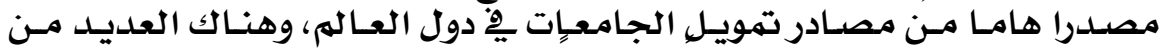

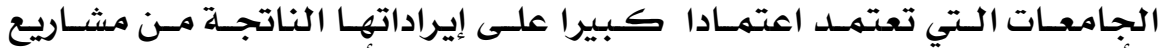

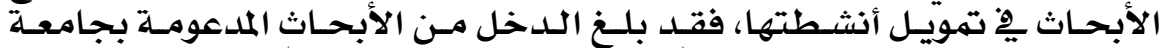

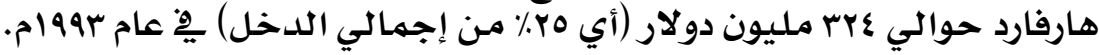

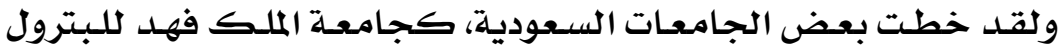

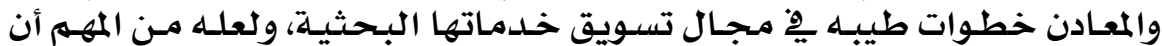

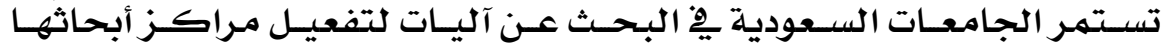

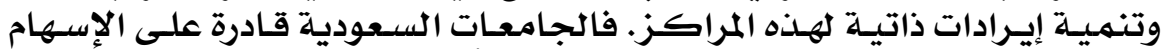

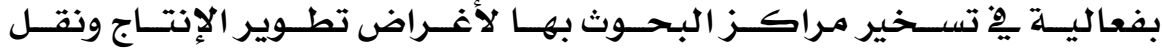

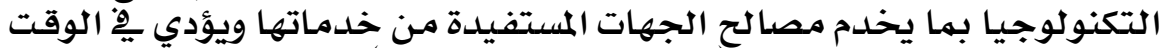

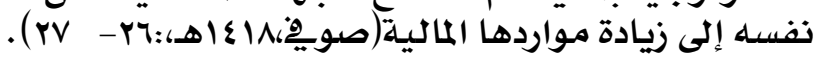

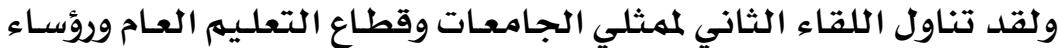

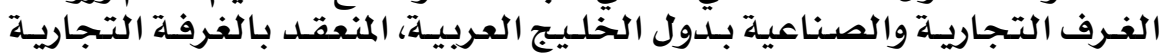

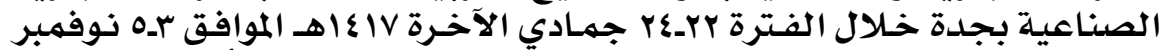

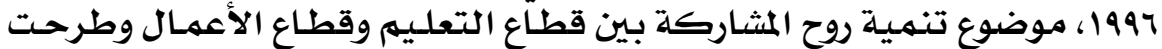

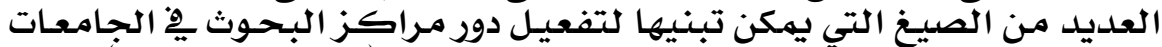

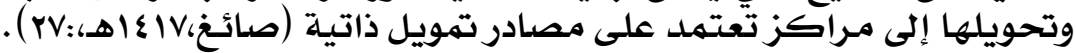

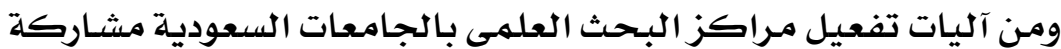

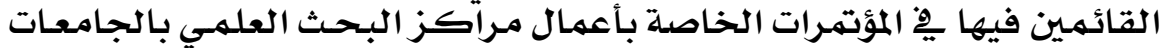

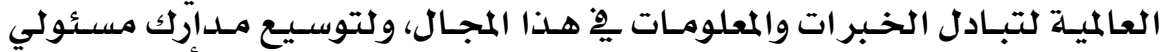

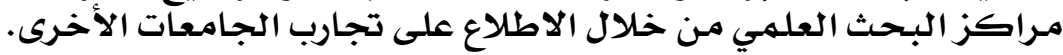

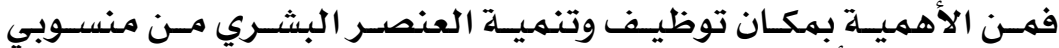

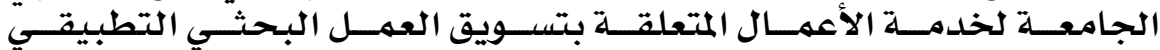

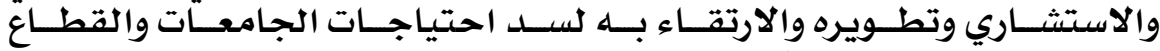

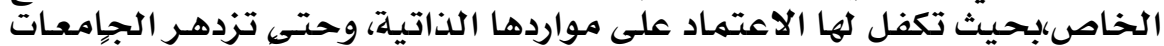

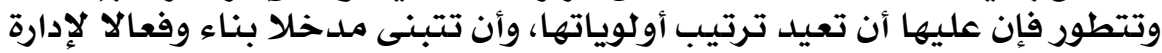

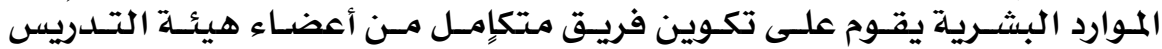

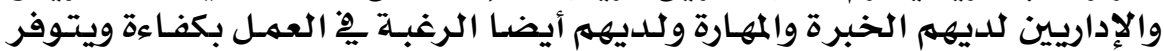

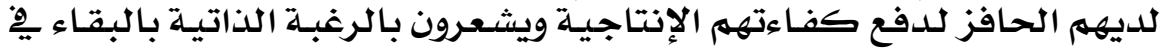

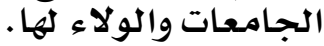

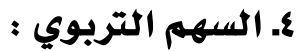

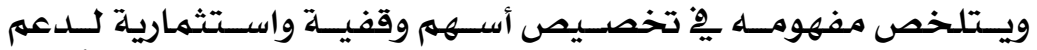

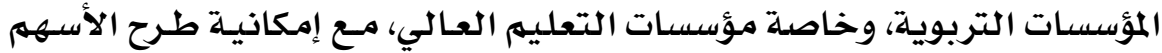

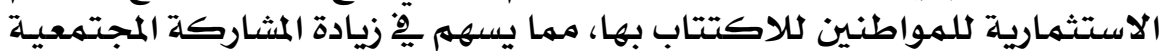

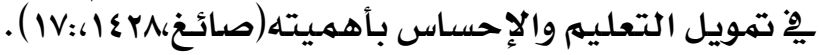

\section{$9+1$}

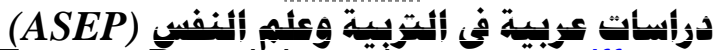


0. الكراسي الجامعية للدراسات والأبحاث :

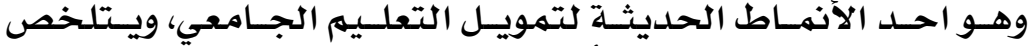

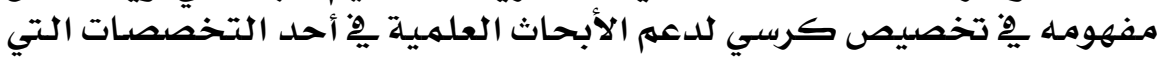

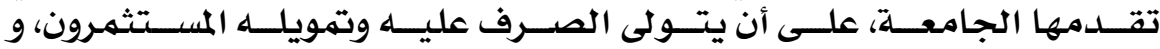

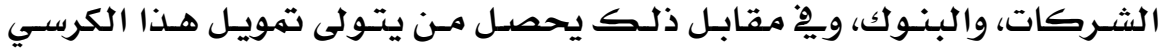

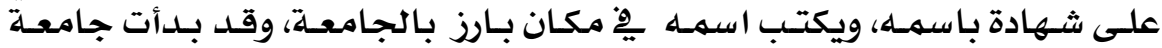

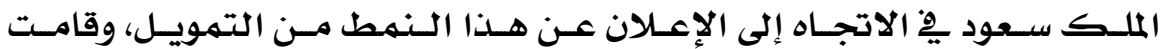

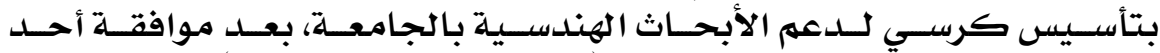

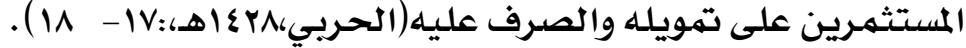

1. ت قروض الطلاب :

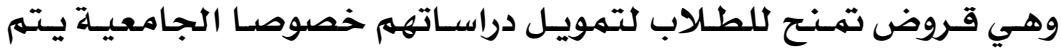

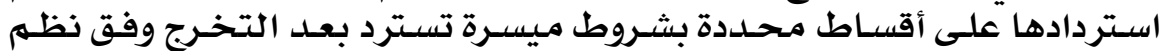

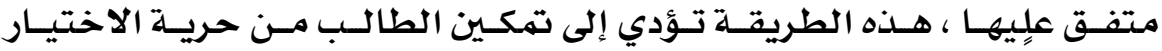

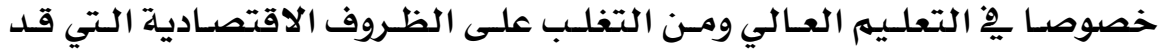
تحول دون مواصلته الدراسـة.

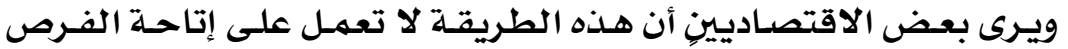

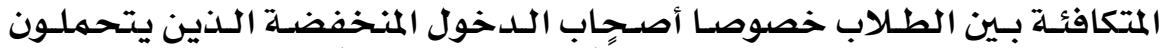

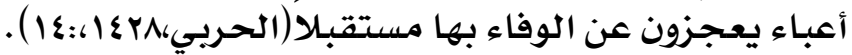

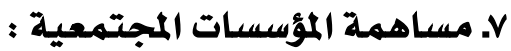

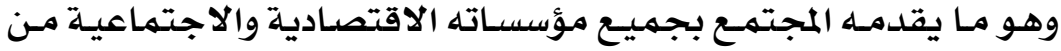

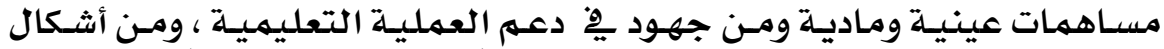

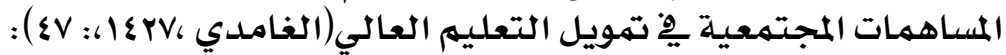

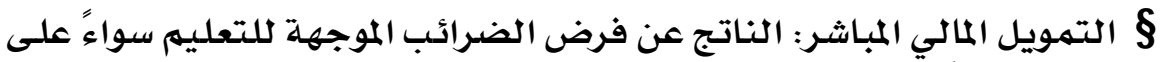

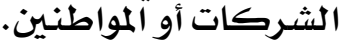

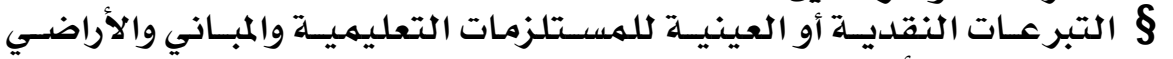

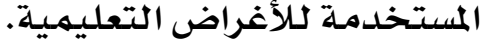

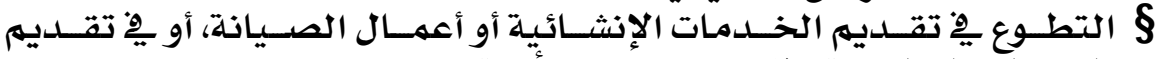

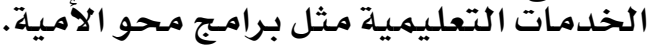

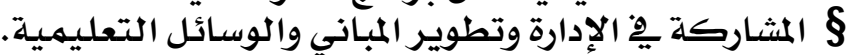

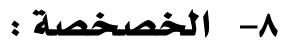

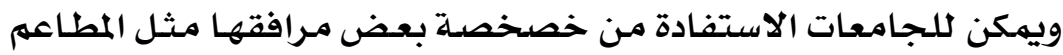

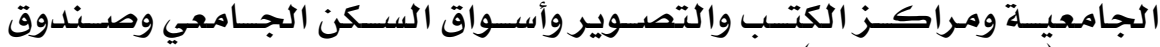

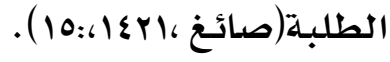
والخصخصة الهنا ثلاثة أنواع هي:

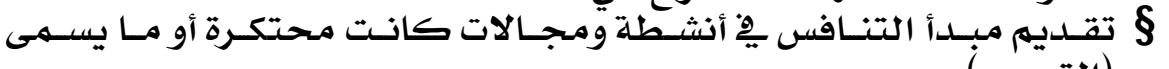
(التحرير).

\section{QF}




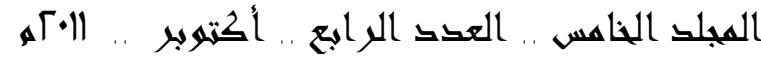

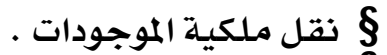

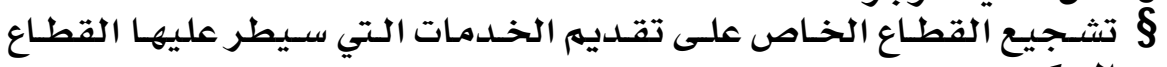
الحكومي.

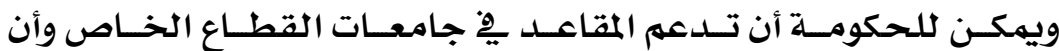

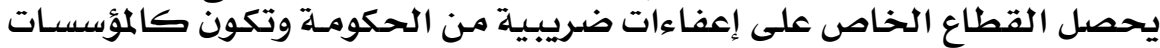

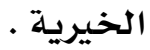

\section{9. الاستثمار فو المرافق التعليمية :}

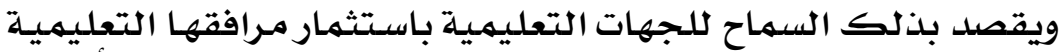

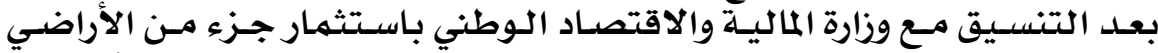

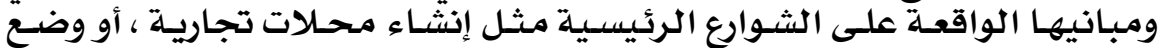

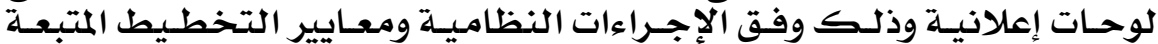

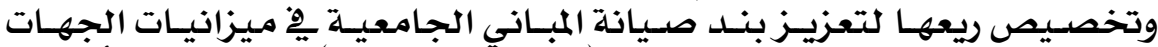

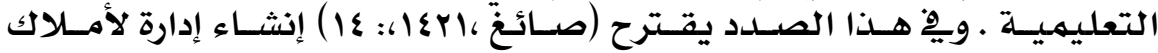

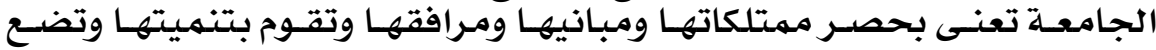

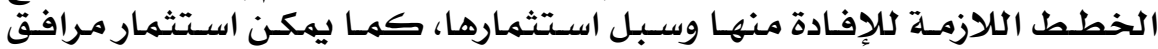

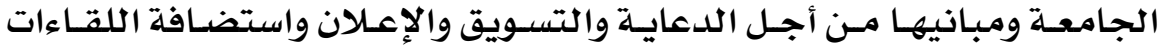

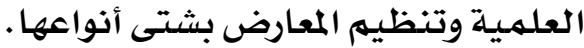

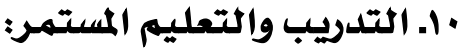

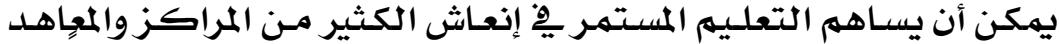

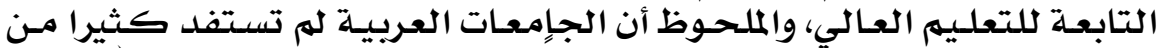

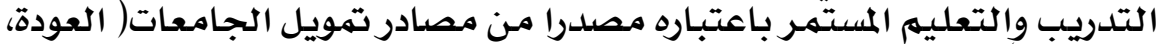
. (V7: : $1 \& 19$

\section{|ll}

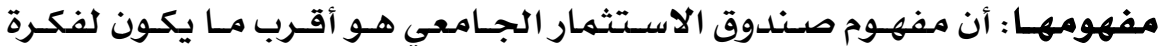

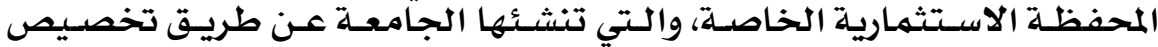

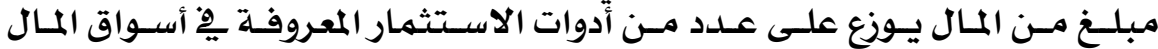

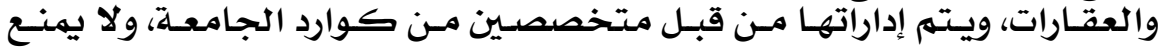

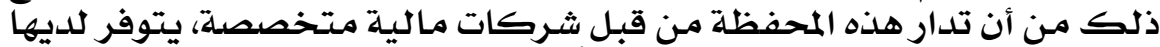

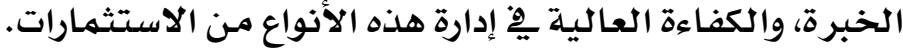

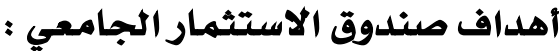

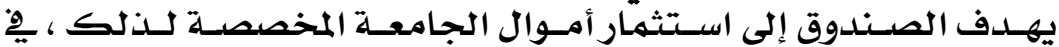

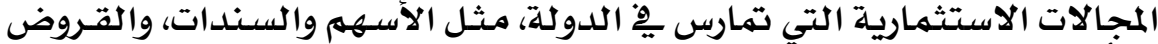

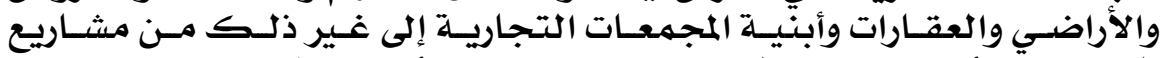

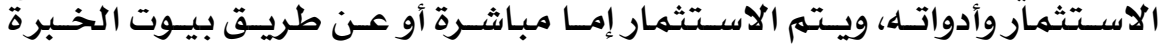

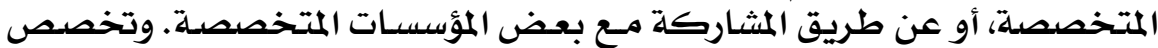

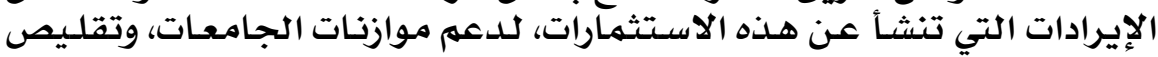

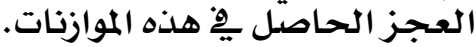

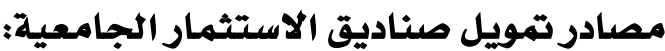

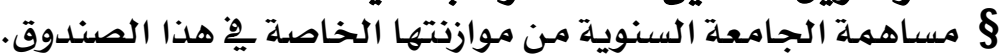

\section{$9 \mu \mathrm{r}$}


المجلد الخاهس .. العكد الرابع .. أكتهوبر .. الآمه

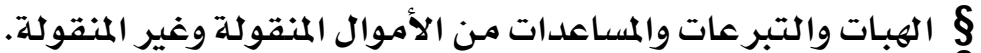

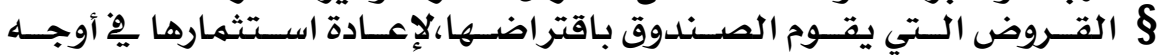

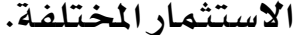

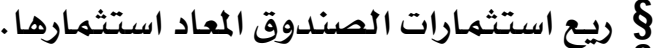

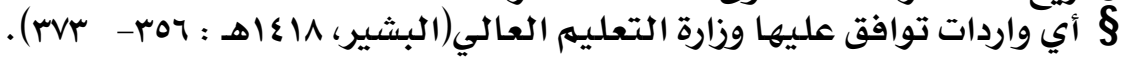

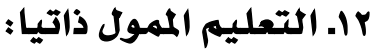

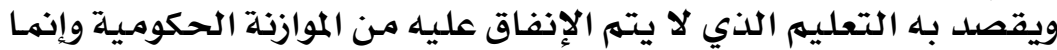

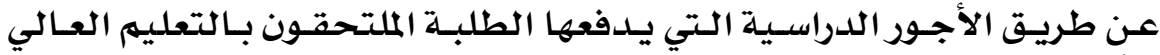

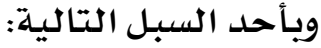

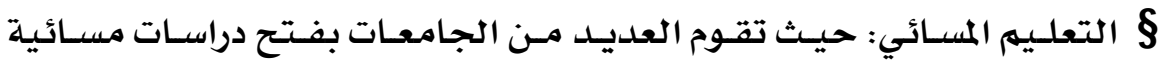

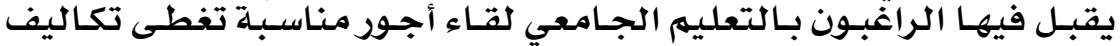

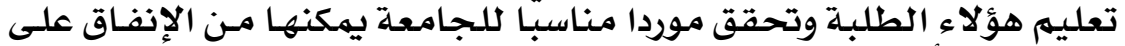
نشاطاتها الأخرى التطي.

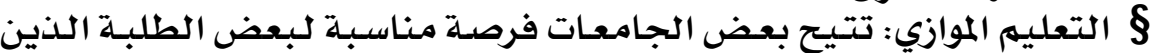

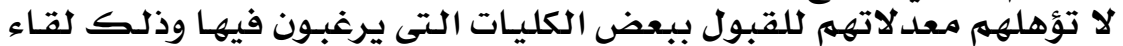

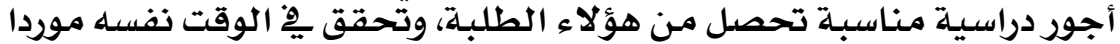

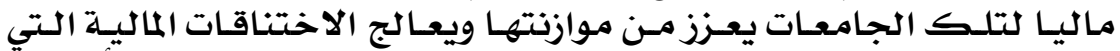

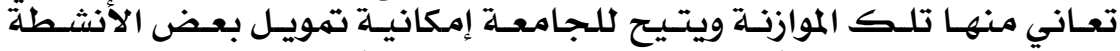

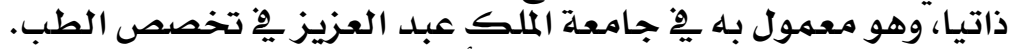

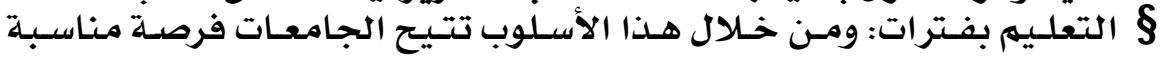

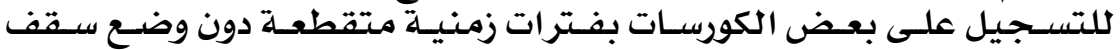

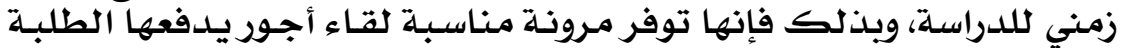

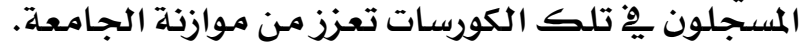

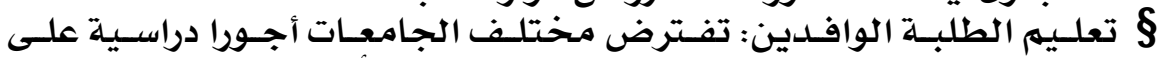

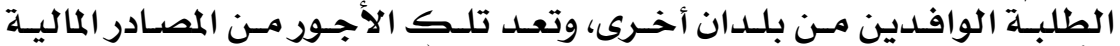

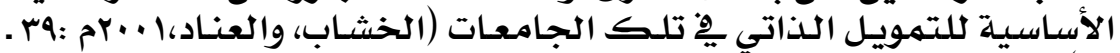

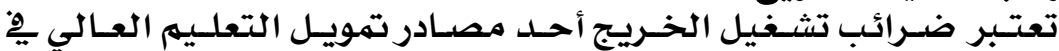

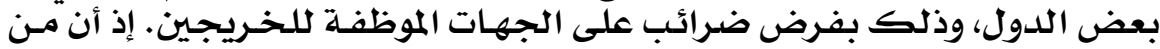

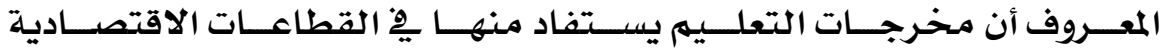

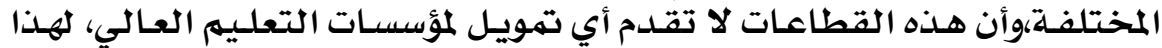

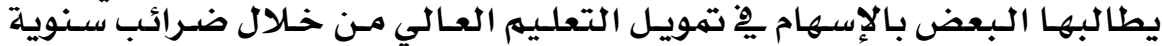

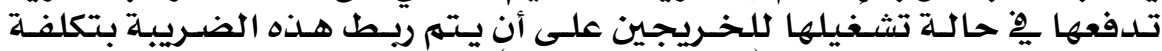

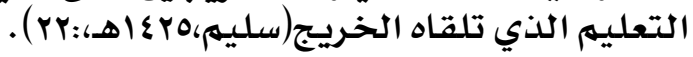

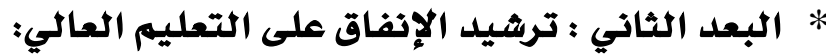

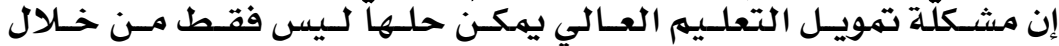

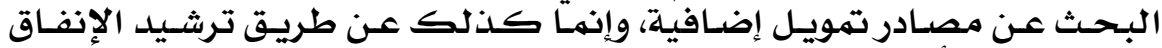

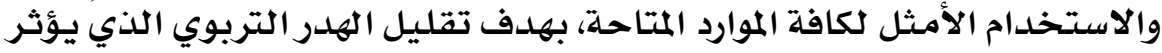

\section{$9 r \varepsilon$}




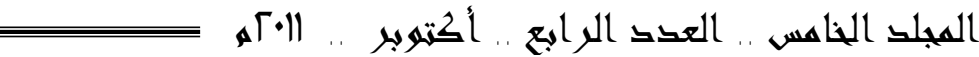

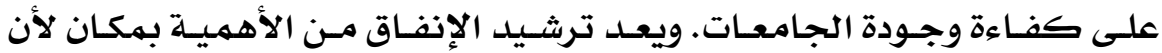

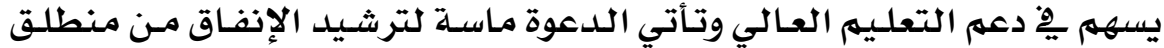

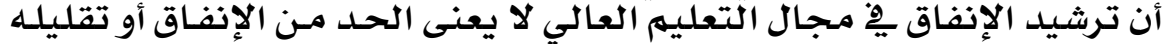

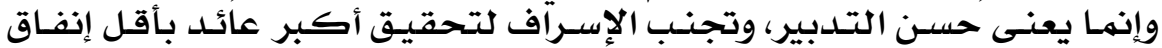

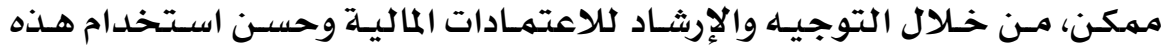

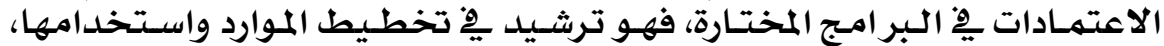

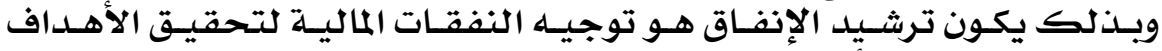

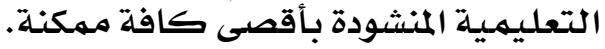

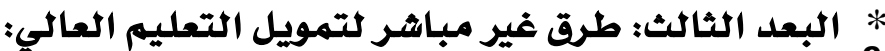

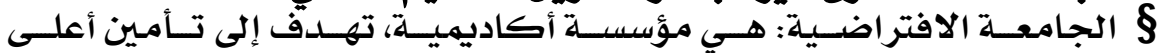

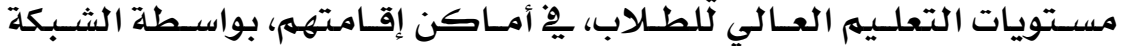

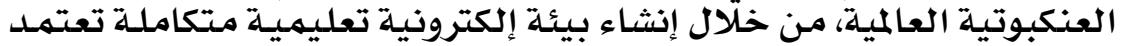

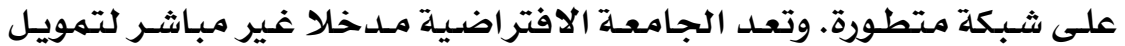

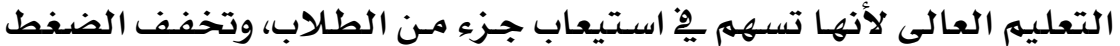

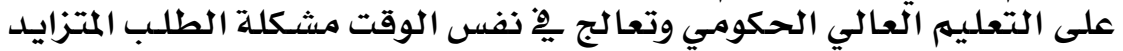

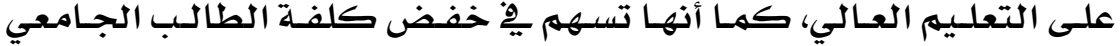

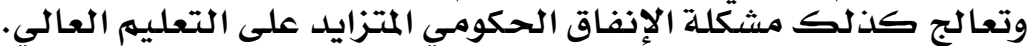

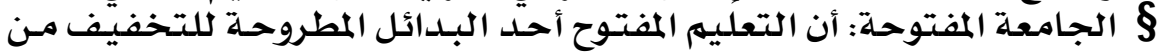

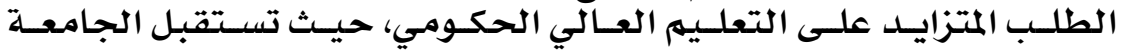

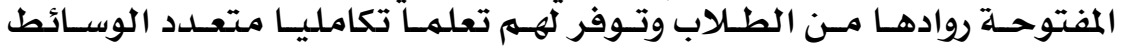

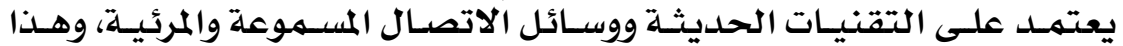

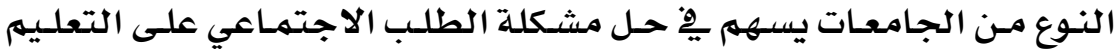

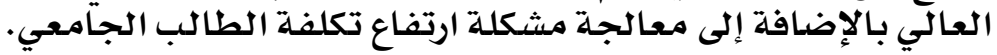

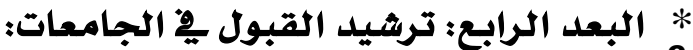

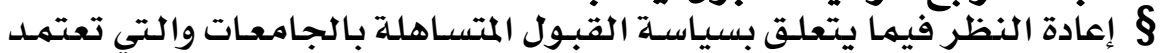

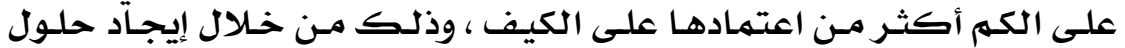

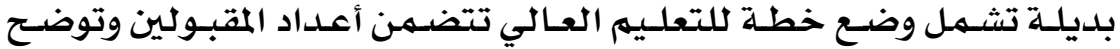

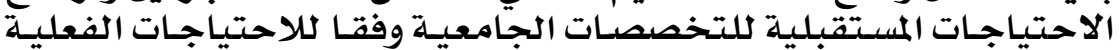

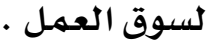

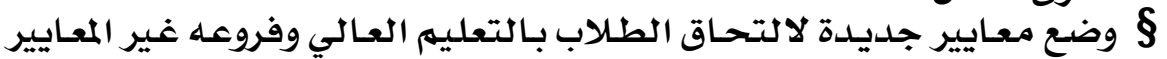

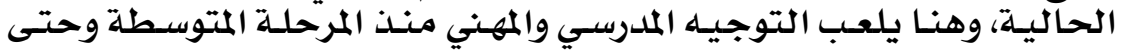

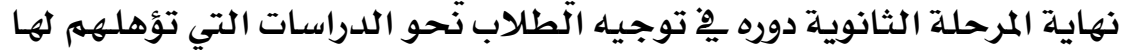

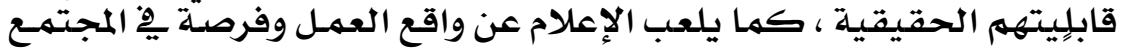

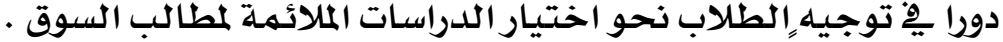

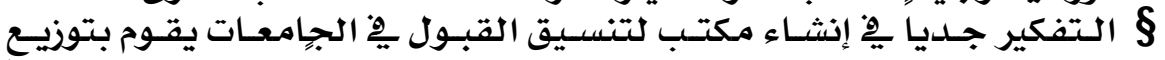

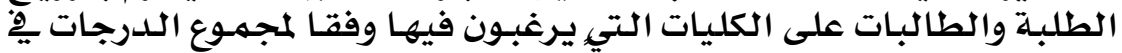

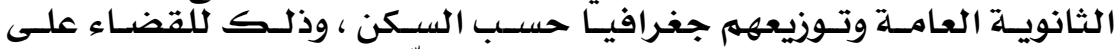

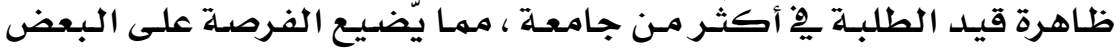

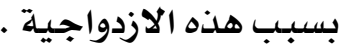

\section{qभ०}




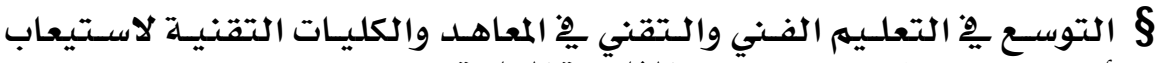

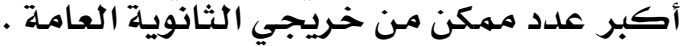

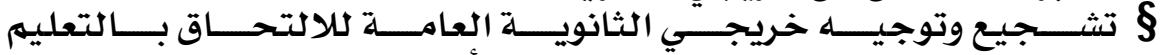

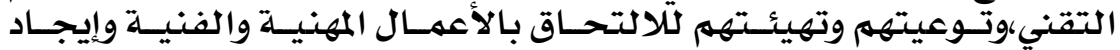

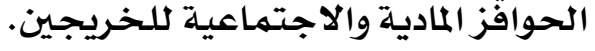

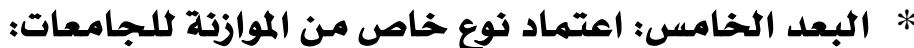

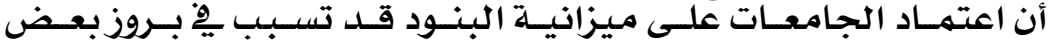

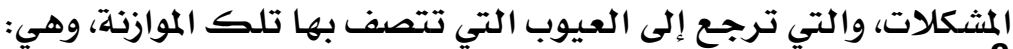

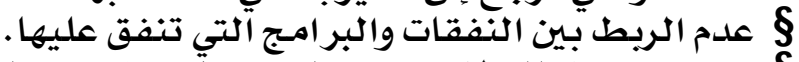

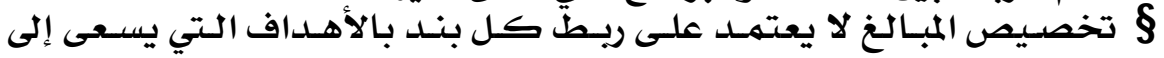

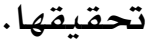
الاعتهماد على الرقابة المستندية.

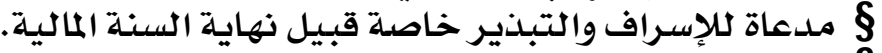

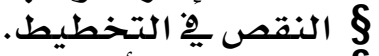

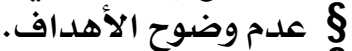
ß مبادئ غير واقعية.

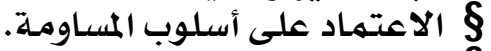

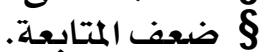

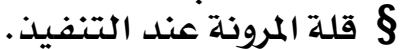

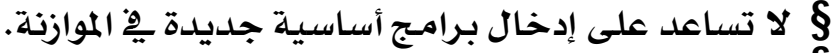

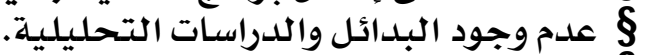

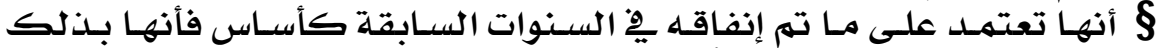

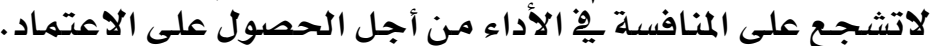

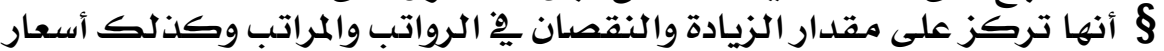

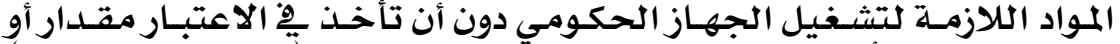

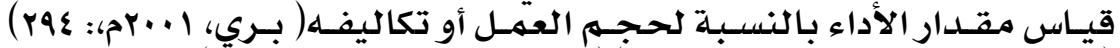

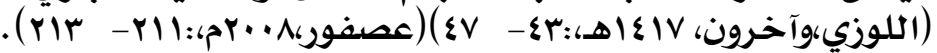

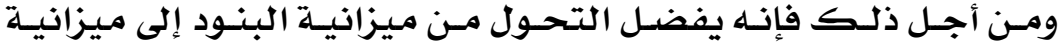

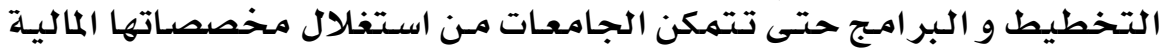

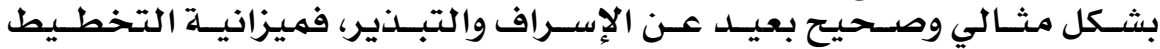

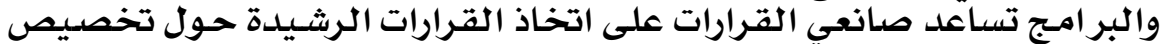

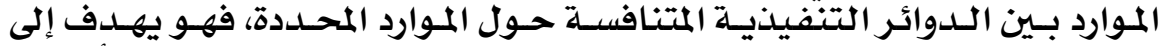

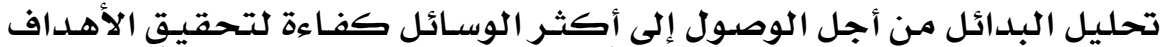

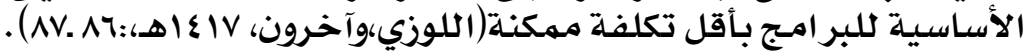

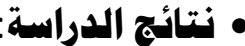

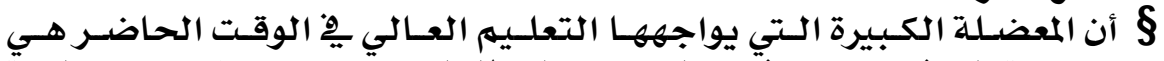

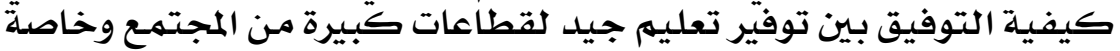

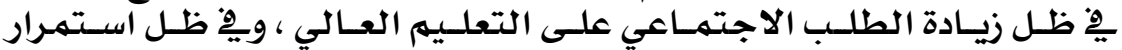

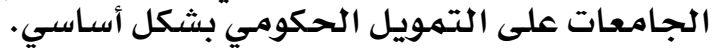

\section{$9+7$}

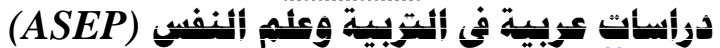




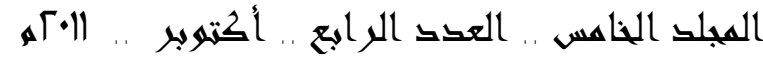

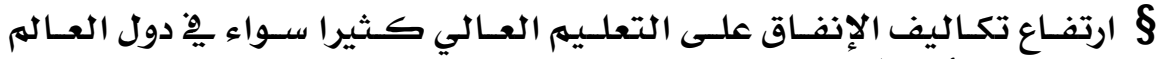

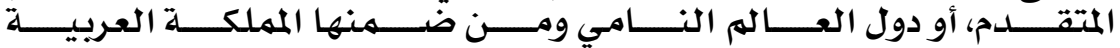

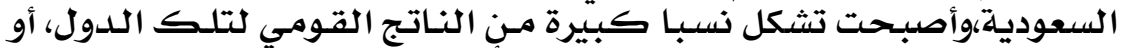

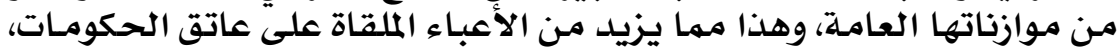

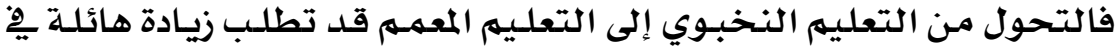

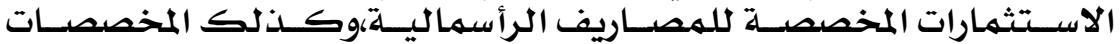

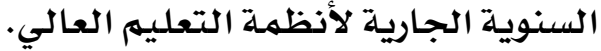

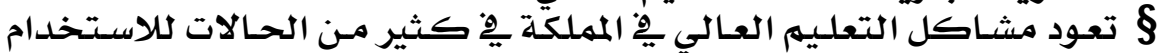

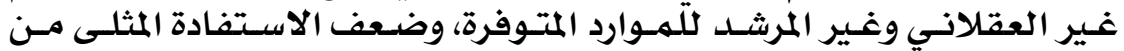

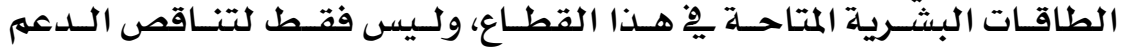

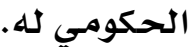

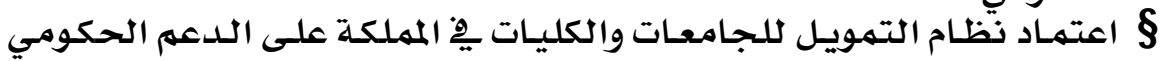

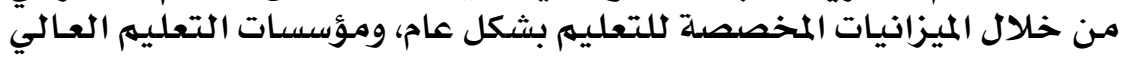

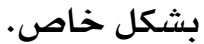

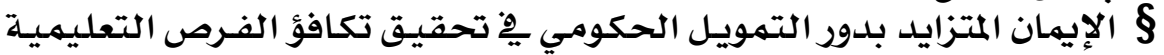

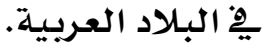

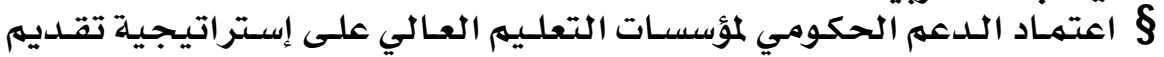

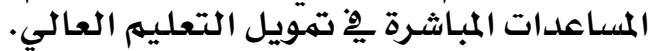

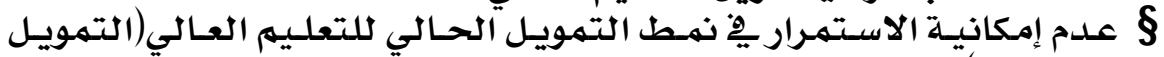

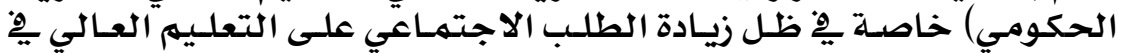

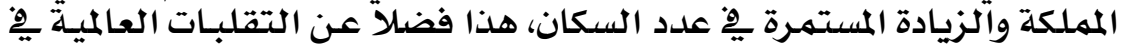

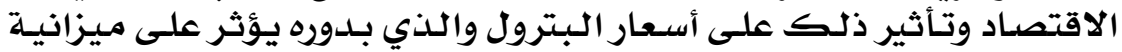

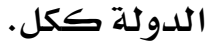

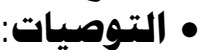

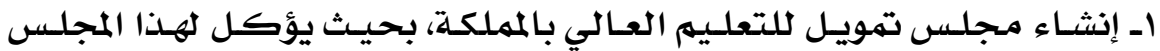

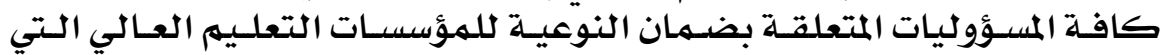
يقوم بتتمويلها.

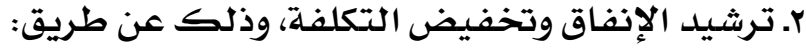

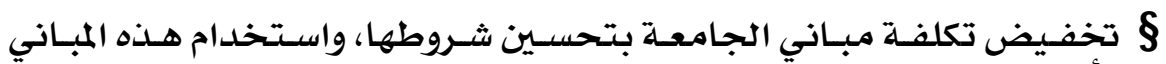

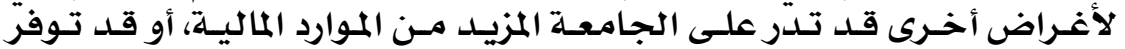

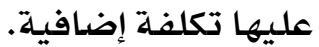

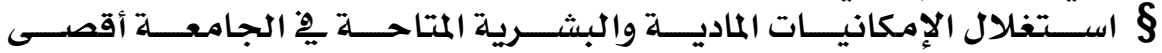

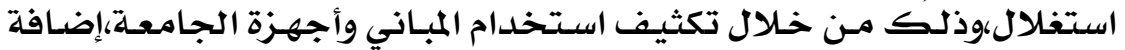

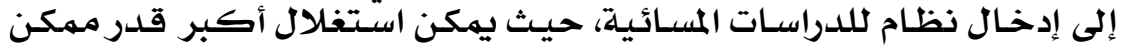

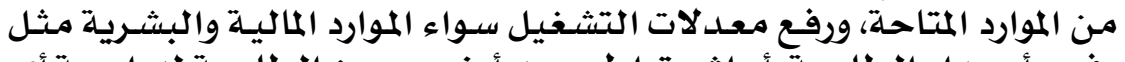

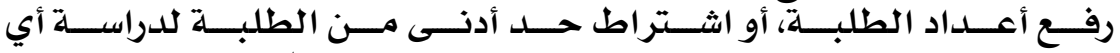

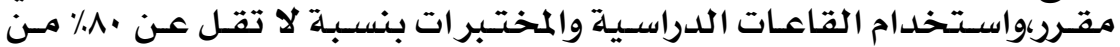

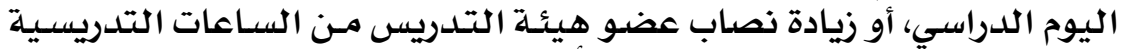

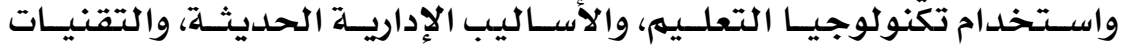

\section{qMV}

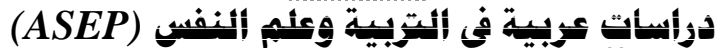




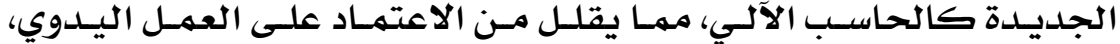

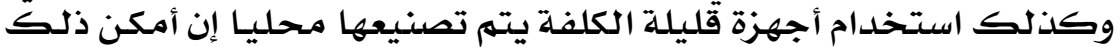

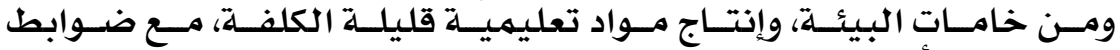

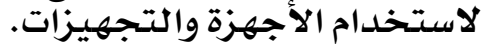

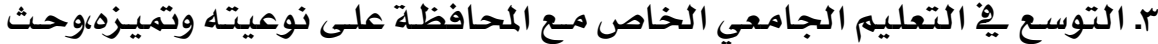

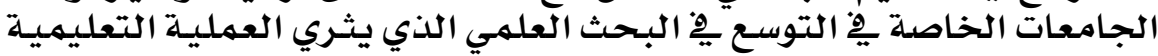

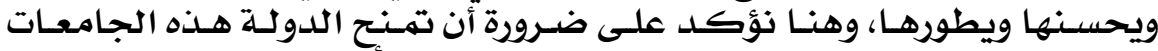

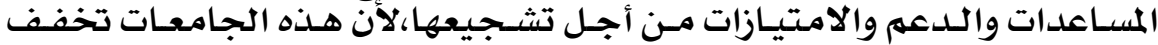

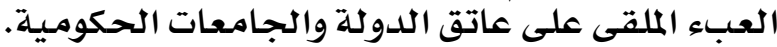

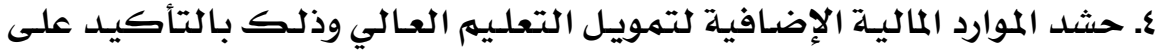

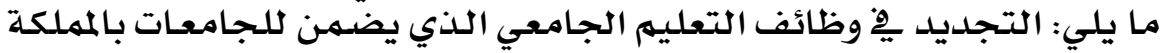

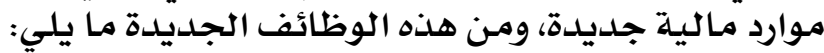

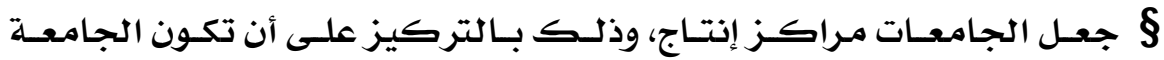

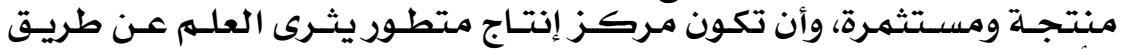

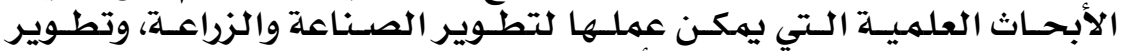

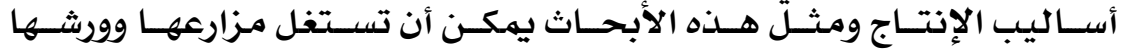

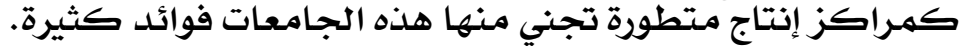

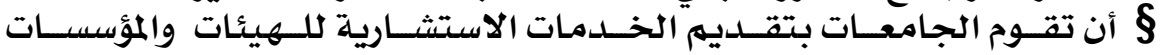

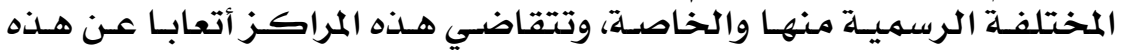
الاستشارات.

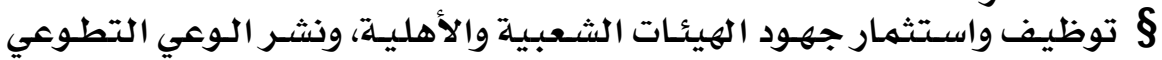

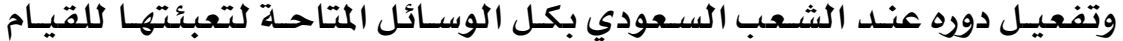

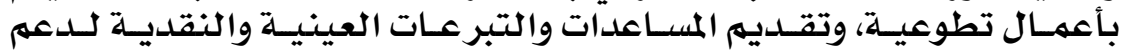

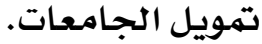

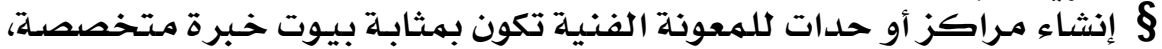

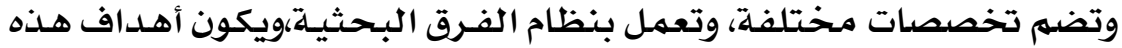

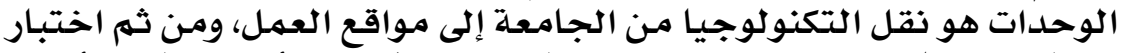

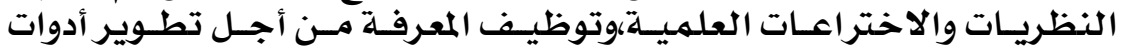

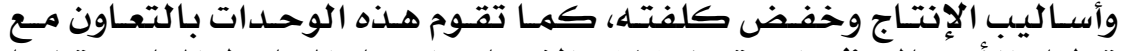

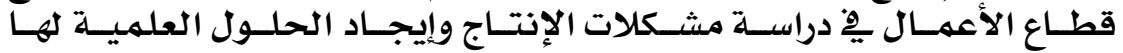

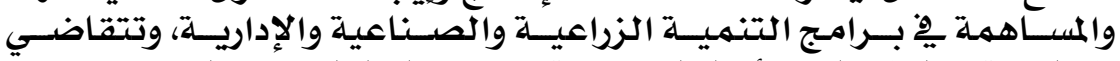

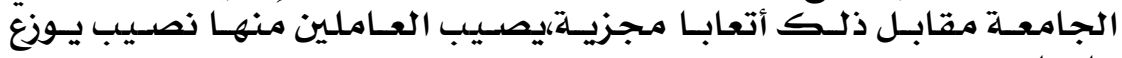
عليها.

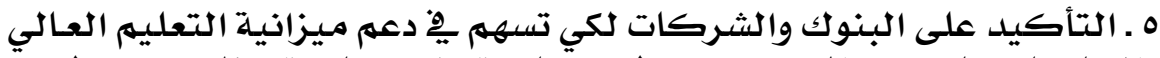

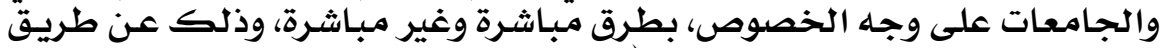

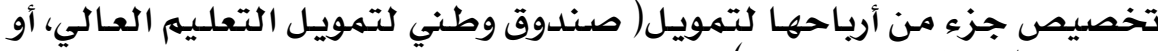
صناديق الاستثمار الجامعية أرية).

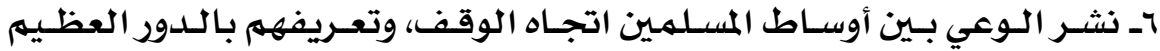

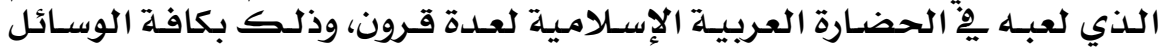

\section{9 r}

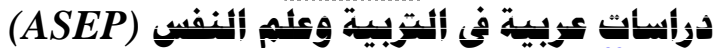




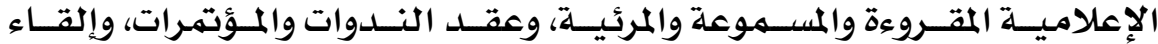

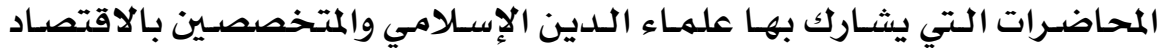

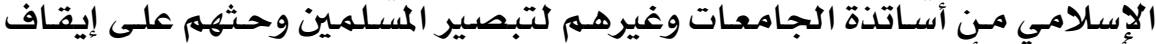

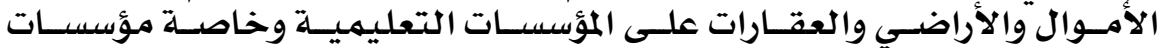

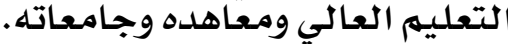

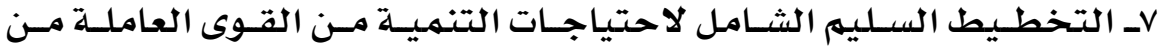

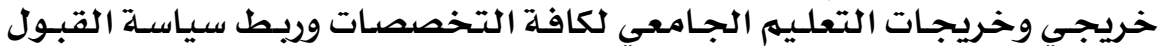

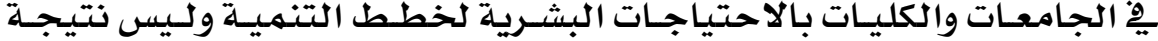

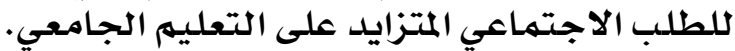

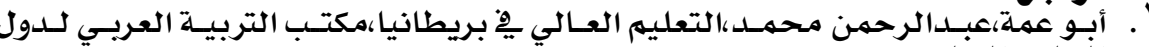

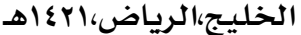

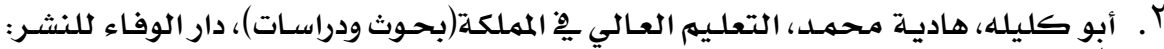

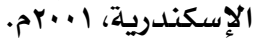

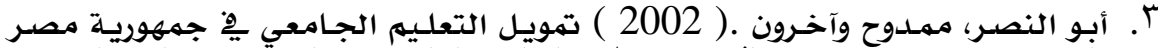

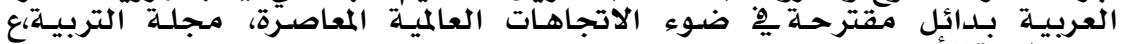

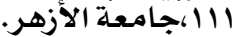

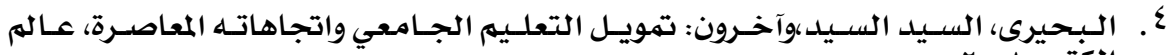

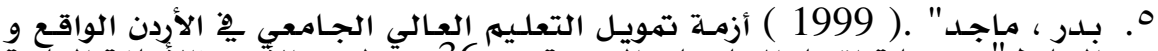

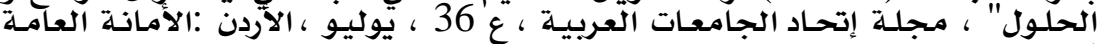

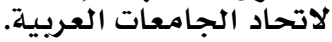
7. بري،زين العابدين،المالية العامـة وميزانية الدولة،وفهرسة مكتبة الملك فهد الوطنية أثناء

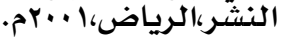

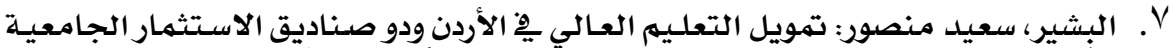

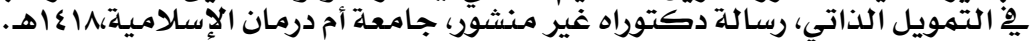

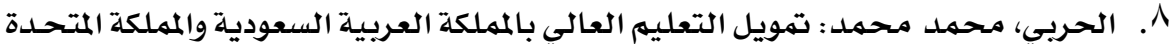

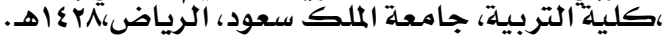

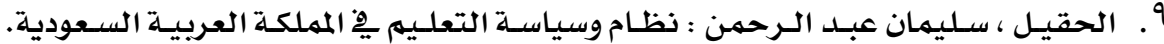

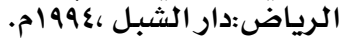

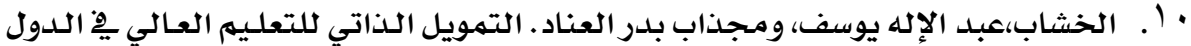

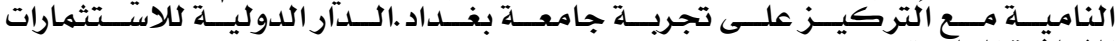

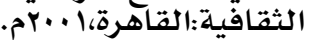

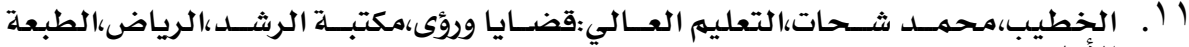

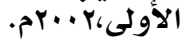

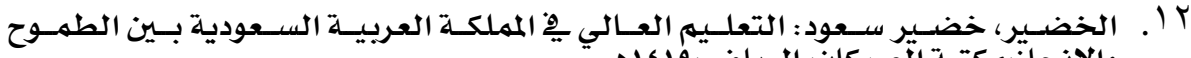

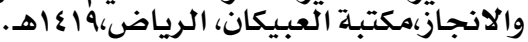

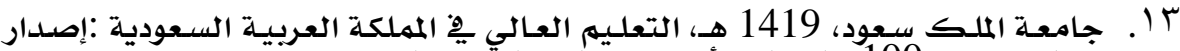
بهناسبة مرور 100 عام على تأسيس المملكة العربيتية السعودية.

\section{9 rq}

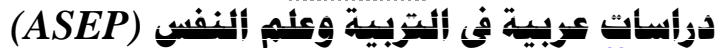




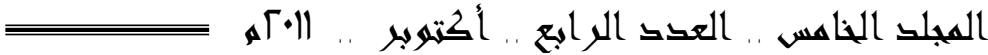

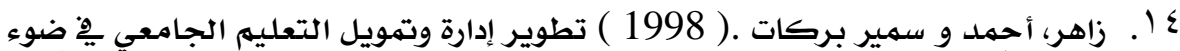

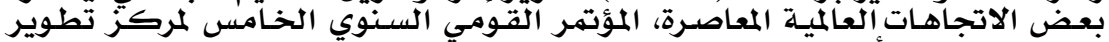

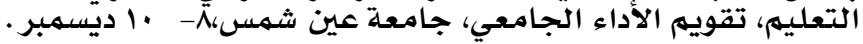

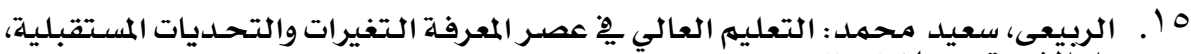

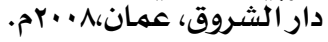

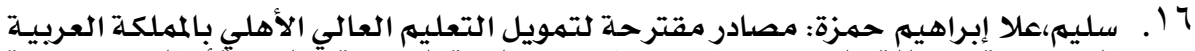

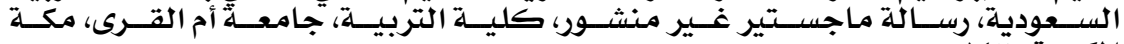

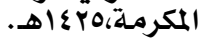

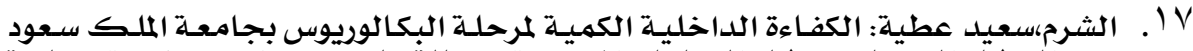

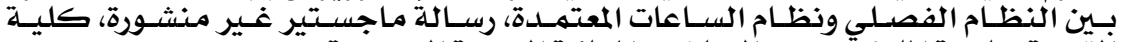

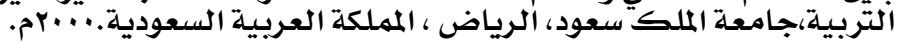

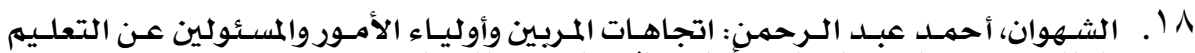

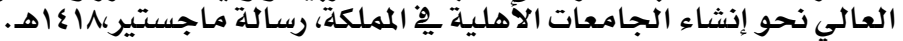

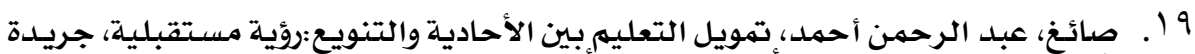

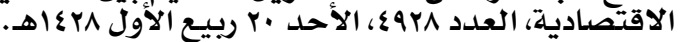

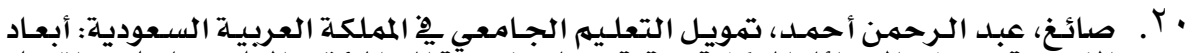

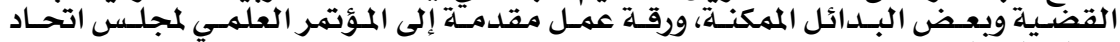

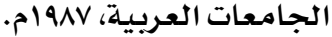

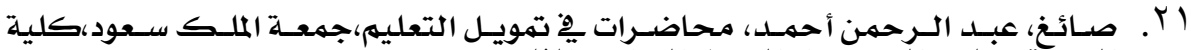

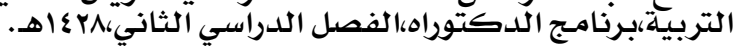

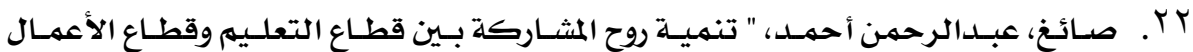

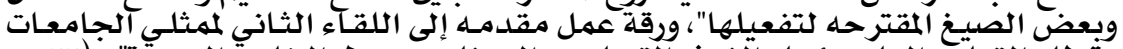

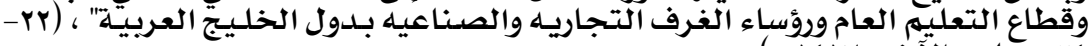

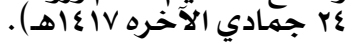

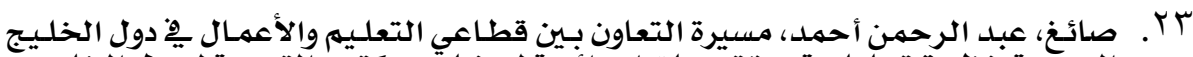

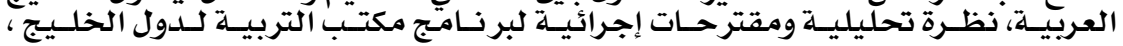

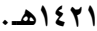

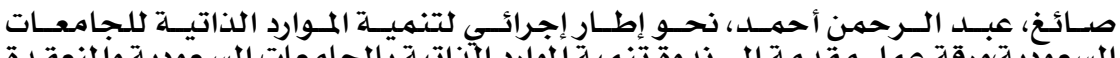

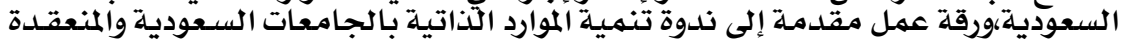

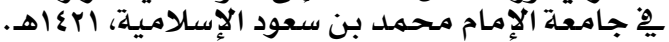

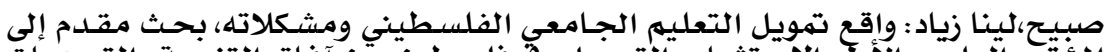

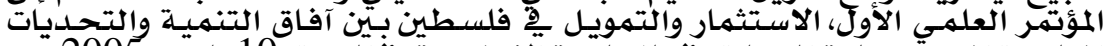

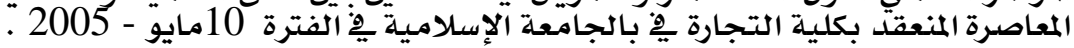

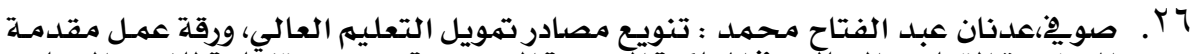

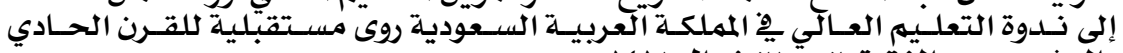

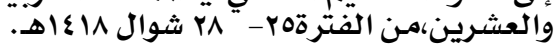

YV

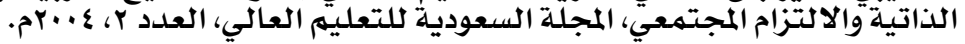

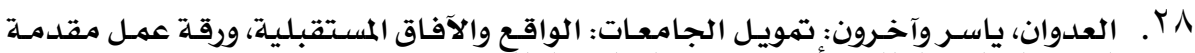

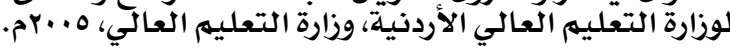

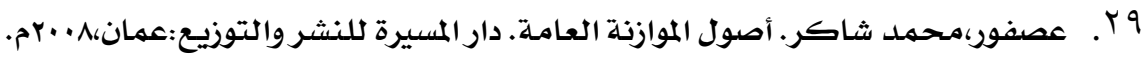

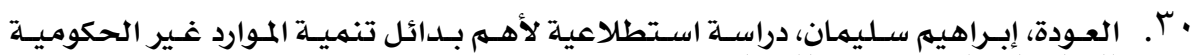

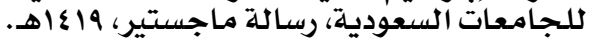

\section{$9 \varepsilon$.}

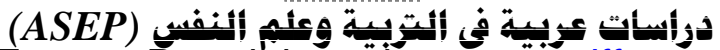




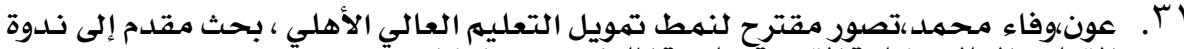

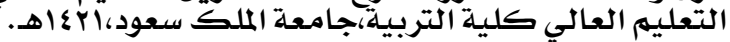

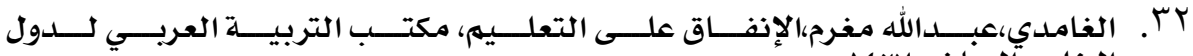

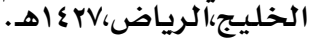

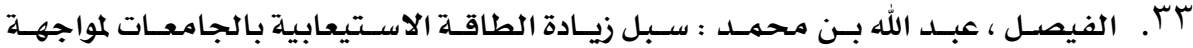

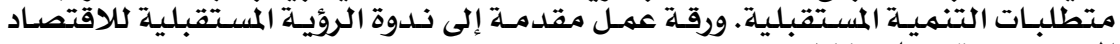

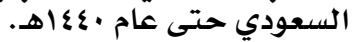

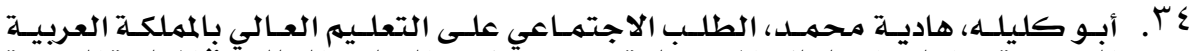

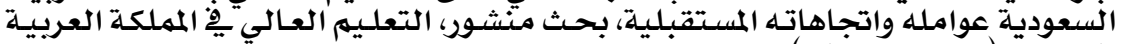

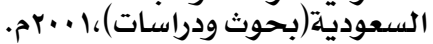

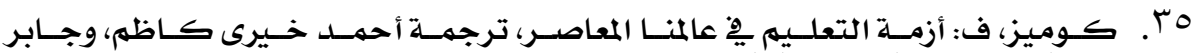

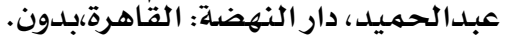

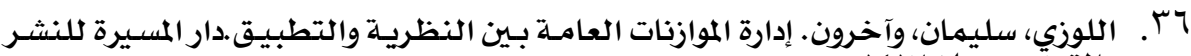

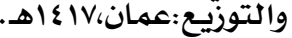

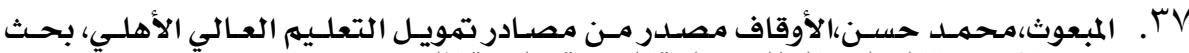

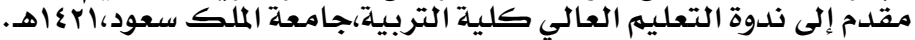

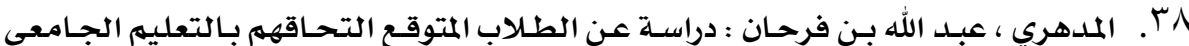

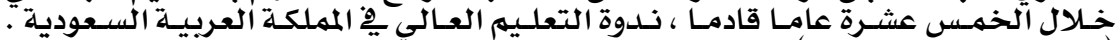

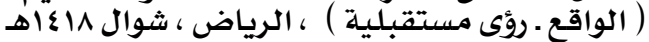

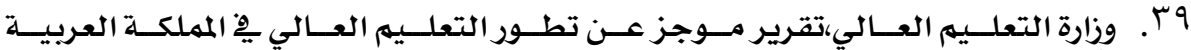

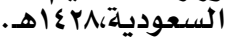

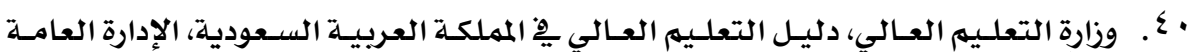

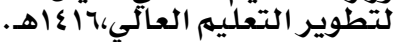

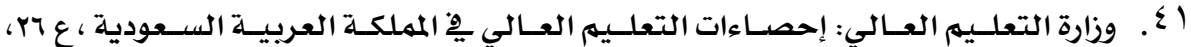

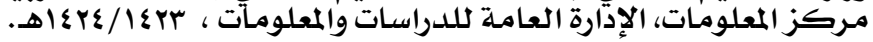

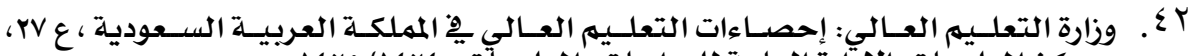

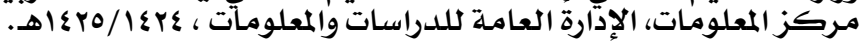

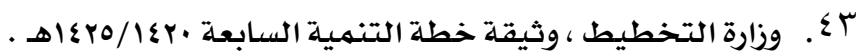

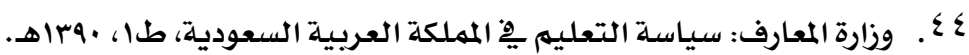

45. http://www.ecoworld-mag.com

46. http://www.planning.gov.sa/

47. www.bab.com/articles.

48. www.bab.com/articles

49. www.mep.gov.sa

\section{$* * * * * * *$}

\section{$9 \& 1$}

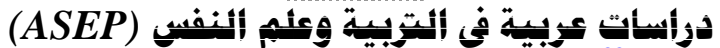

